\title{
PREPARAÇÃO E CARACTERIZAÇÃO DE DISPERSÕES DE ANFIFILICOS SINTÉTICOS
}

Tese de Doutoramento apresentada junto ao Departamento de Bioquímica do Instituto de Química da Universidade de São Paulo Orientador: Hernān Chaimovich 
"... O homem é sempre a presa de suas verdades. Uma vez reconhecidas, não pode libertar-se delas. Um homem que se torna consciente do absurdo fica-the ligado para todo o sempre...

... impotente para realizar o transcendente, in capaz de sondar a profundidade da experiência.

... não traz nada de novo. Não encontrou nada na experiência a não ser a confissão da sua impotência, sequer um pretexto para inferir qualquer principio satisfatório...

O nosso apetite de compreender, a nossa nosta gia do absoluto só são explicáveis na medida em que, justamente podemos compreender e explicar muitas coisas. E vão negar absolutamente a razão. Ela tem sua ordem na qual é eficaz. E a da experiêneia humana. Por isso mesmo queremos tornar tudo claro. Se o não conseguimos, se o absurdo nasce dessa ocasião, é justamente no encontro dessa razão eficaz mas limitada, e do irracional sempre renascente. As leis da natureza podem ser vălidas até certo limite, passado o qual se voltam contra si próprias, a fim de fazerem nascer o absurdo. Ou ainda podem legitimar-se no plano da descrigão, sem por isso serem verdadeiras no da explicação. o homem ab surdo reconhece a luta, não despreza em absoluto a razão e admite o irracional. Cobre assim com o othar todos os dados da experiência e estā pouco disposto a saltar antes de saber. Sabe sómente que nessa consciência atenta jă não hã lugar pa ra a esperanga..."

A. camus. 


\section{AGRADECIMENTOS}

Ao Hernan, por uma irrestrita compreensão da multiplicidade,

$\AA$ Lenise, pelo estimulante companheirismo e pe las discussões (científicas ou não) sempre enriquecedoras,

Ao Sérgio, por minha iniciação no laboratório e por um exemplo vivo de dedicação ao trabalho e de criatividace,

A Cuccovia, por um senso crítico aguçado e por inūmeros favores objetivos,

Ao Araújo, pela disponibilidade do laboratório, pelas osmolaridades e pelos berros entusiastas,

A Shirley, por uma loucura solar que não deixa o juĩzo apodrecer,

Ao sangue novo do grupo (Leo, Lücia, Valéria, Mercedes e Cida) pela felicidade de me tornarem um pouco ne cessāria,

A Regina, Valdir, Dino e Carlos Eduardo pela alegria dos cafézinhos,

A Maria Helena, pela extravagância que faltava ao grupo,

A Neusa, pelo capricho com que desempenha suas funções,

A Edjane e à Benê, respectivamente, pelo forne cimento de material e pelos cafézinhos, 
Ao Dr. Sesso e ao Hélio, pelas microscopias eletrônicas,

A Laura, pela datilografia rápida e precisa,

A FAPESP, pelos proventos,

A Ana Carolina, por uma vontade ilimitada de aprender e por ter me escolhido como orientadora,

Ao José Alberto, por Ana Carolina e por "otras cositas mas"... 
Atendendo a insistentes pedidos, agradeço EM CARICATURA

Ao Hernan, pela abertura,

A Cuccovia, pela fechadura,

Ao Araújo, pela turbulência,

A Lenise, pela coerência,

As aprendizes (Lúcia, Valéria, Mercedes e Cida) pelo tormento, A todos pelo alento, A FAPESP, pelo alimento, 


\section{INDICE}

Pāgs .

INTRODUÇÃO $\ldots \ldots \ldots \ldots \ldots \ldots \ldots \ldots \ldots \ldots \ldots \ldots \ldots \ldots \ldots \ldots \ldots \ldots$

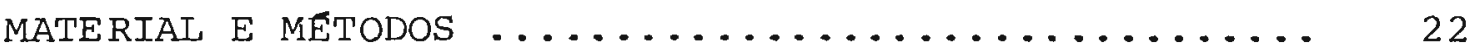

1. Preparação de vesículas pequenas de DODAC .... 23

2. Preparação de lipossomos grandes de DODAC por vaporização de $\mathrm{CHCl}_{3} \ldots \ldots \ldots \ldots \ldots \ldots \ldots \ldots \ldots . \ldots \ldots$

3. Microscopia eletrônica de lipossomos grandes

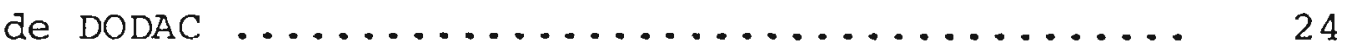

4. Determinações de volume do compartimento aquoso interno $\ldots \ldots \ldots \ldots \ldots \ldots \ldots \ldots \ldots \ldots \ldots . \ldots \ldots \ldots$

5. Determinações de radioatividade em amostras

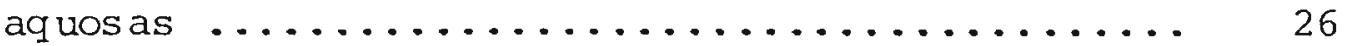

6. Determinações de propriedades osmóticas ...... 26

7. Determinações de transição de fase .......... 28

8. Efeito da temperatura sôbre $v$ 을 $\mathrm{S} \ldots . . . \ldots .28$

9. Determinações de permeabilidades relativas .... 29

10. Determinações de permeação de prótons ........ 30

11. Preparação de lipossomos grandes de dicetilfosfato de $\mathrm{Na}^{+}(\mathrm{DCP}) \quad \ldots \ldots \ldots \ldots \ldots \ldots \ldots \ldots . \ldots . \ldots . \ldots$ 12.

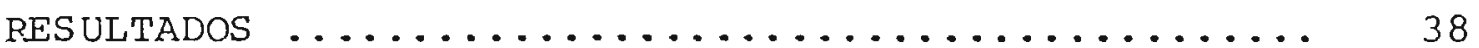

1. Caracterização física de dispersões de DODAC .. 38

2. Caracterização funcional de dispersões de DODAC 
Pāgs .

2.1. Impermeabilidade à sacarose, incorporação e adsorção de sacarose .............. 41

2.2. Permeabilidades relativas ao $\mathrm{KCl} \ldots \ldots . . .45$

2.3. Propriedades osmōticas ............. 52

2.4. Permeação de $\mathrm{H}^{+}$e/ou $\mathrm{OH}^{-} \ldots \ldots \ldots \ldots \ldots 64$

2.4.1. Mudança de fluorescência da 2 aminopiridina $\ldots \ldots \ldots \ldots \ldots \ldots \ldots \ldots$

2.4.2. Mudança da absorbância de uma mis tura de corantes indicadores de $\mathrm{pH} \ldots \ldots \ldots \ldots \ldots \ldots \ldots \ldots \ldots \ldots$

3. Obtenção de lipossomos grandes de DCP ........ 74

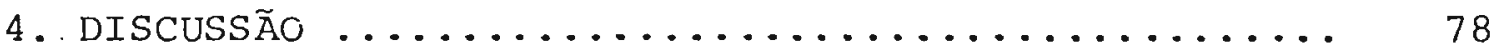

5. RESUMO $\ldots \ldots \ldots \ldots \ldots \ldots \ldots \ldots \ldots \ldots \ldots \ldots \ldots \ldots \ldots \ldots \ldots$

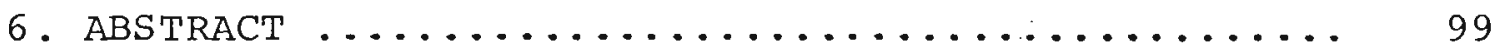

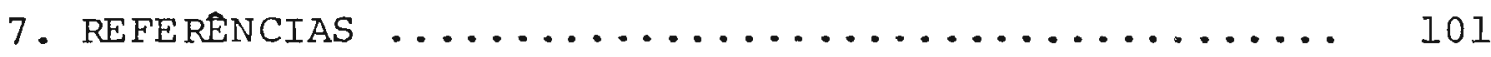


INTRODUÇÃO

Membranas biológicas cumprem inūmeras funções simultâneamente : organizam moléculas em diferentes compartimentos, limitam microambientes adequados para funções vitais e controlam o transporte de várias substâncias, para citar alguns exemplos. Essa multiplicidade funcional, origina, naturalmente, alguns problemas para os investigadores do transporte em membranas. Pox exemplo, pouco se pode verificar experimentalmente a respeito do agente ou agentes causais da diferença de potencial transepitelial medida através de uma pele de sapo (Carmona, 1979). A pele é abordada como uma "caixa prêta" em relação à eletrogênese e modelos propostos teoricamente para explicar essa diferença de potencial são de difícil verificação experimental. Gene ralizando, a complexidade das membranas naturais vem dificultando verificações experimentais das inümeras teorias até hoje desenvolvidas para o tratamento de potenciais trans membrana (Lakshminarayanaiah, 1974, 1975, 1979). A correlação estrutura-função é raramente possível justamente em decorrência da simultaneidade das múltiplas funções e da di versidade das inúmeras estruturas. Duas condições são necessárias para se descer a um nível molecular de investigação : 1) a simplificação estrutural e química do sistema ; 2) o isolamento de cada um dos fenômenos simultâneos.

Em termos de transporte, isso implicaria em controle das condições exteriores à membrana, da espécie 
transportada e da pröpria estrutura físico-química da membrana que transporta. Nesse sentido, a investigação de fe nômenos isolados em modelos de membrana resulta muito promissora. Potenciais transmembrana, continuando com o exem plo, tiveram algo de sua natureza esclarecido graças a estudos com modelos de membrana (Tien, 1974; 1976; 1979; Jain, 1972; Jain e Wagner, 1980).

Desde 1956, quando Teorell apresentou um mode lo de perspex para demonstrar a aplicabilidade da Físico Química ao estudo de membranas biológicas, inúmeros siste mas-modelo de membranas vêm sendo propostos (evidentemente, Teorell sabia que seu modelo não explicava propriedades tão fundamentais das membranas biológicas como uma seletividade $\mathrm{Na}^{+} / \mathrm{K}^{+}$da ordem de $30: 1$, uma condutância dependente da voltagem, uma difusão facilitada ou um transporte ativo). Robertson, em 1959, postulou a teoria universal da membrana unitāria extensiva a todas as células e organelas. Muel ler et al. (1962) descreveram uma técnica de preparação de modelos de membrana à partir das pröprias moléculas consti tuintes das mesmas. Atualmente, a composição molecular quantitativa de uma grande variedade de membranas biológicas tais como, as de eritrócitos, mitocôndria, fragmentos de bordo em escova, bastonetes de retina e certas membranas plasmáticas é conhecida (Rouser et al., 1968). Lípides extraídos dessas membranas podem ser utilizados para a preparação de diversos sistemas-modelo de membrana que per mitem reproduzir, de forma selecionada e simplificada, alguns dos fenômenos que ocorrem em membranas naturais 
(Gomperts, 1977). O modelo mais elementar de membrana é um filme monomolecular de lípides como o de Gorter e Grendel (1925). Fosfolípides em quantidades conhecidas extraídos de eritrócitos flutuam em uma superfície aquosa sendo confi nados entre três lados fixos e um quarto lado móvel, uma es pécie de barra flutuante, em um recipiente de Langmuir (Lang muir, 1920). Essa barra é movida no sentido de se confinar - material superficial numa área cada vez menor atê que um filme monomolecular coerente se forme na superfície da āgua. Pode-se, assim, medir a força necessária para se manter o filme superficial. Nessas monocamadas, o empacotamen to e as forças eletrostáticas superficiais de anfifílicos podem ser investigados. Todavia, o filme monomolecular se constitui apenas em um "modelo pela metade" muito embora ve nha sendo intensivamente estudado hä mais de 60 anos (Davies et al., 1963; Gaines, 1966; Adam, 1968).

Do ponto de vista estrutural, uma solução mais adequada ao problema de "modelar" uma membrana plasmática é representada pelas bicamadas planas. Pincelando uma solução de fosfolípides em solvente orgânico sôbre um oríficio de, aproximadamente, lmm produz-se um filme fosfolipïdico observāvel através de uma lupa (Mueller et al., 1962a; Muel ler et al., 1962b; Mueller et al., 1963; Muellex et al., 1964). O filme afina espontaneamente à medida que o solven te difunde para as soluções aquosas nas quais foi parcialmente submerso até que se obtém a camada bimolecular que se caracteriza por um padrão de interferência destrutiva para a luz refletida, ou seja, pela côr preta. O arranjo físico 
dessas bicamadas torna possível medir parâmetros elétricos das mesmas como : capacitância, condutividade, voltagem, po tenciais de membrana e ainda, voltagens de ruptura, a qual ocorre tipicamente em torno de $200 \mathrm{mV}$ (Haydon, 1968; Henn e Thompson, 1969). Transporte seletivo de íns ou moléculas neutras tambēm pode ser convenientemente estudado nas BIM ("black lipid membranes") com o auxílio de marcadores radio ativos. A velocidade de permeação de não-eletrólitos polares através das BLM mostrou ser apreciavelmente menor que a da água (Jain, 1972; Tien, 1974). Em flagrante contraste com as membranas biológicas, permeabilidades iônicas resultaram acentuadamente baixas (Jain, 1972), resistências elétricas extremamente altas, diferenças de potencial lineares com a corrente aplicada e seletividade entre cátions praticamente nula (Mueller et all., 1962b; Mueller et al., 1964; Mueller e Rudin, 1969; Cole, 1968). A razão para essa dispariảade de comportamento em relação às membranas biológicas parece ser a ausência de vias moleculares paralelas à barreira resistiva como os poros (canais preenchidos por água) ou os ionöforos, capazes de regularem fluxo de íons. Outro problema do modelo é o solvente orgânico alterando capacitância e espessura da bicamada. Ao se utilizar uma série homó loga de hidrocarbonetos parafínicos como solventes de lecitina, a capacitância aumenta e a espessura diminui à medida que o número de carbonos do solvente aumenta (Fettiplace et al., 1971). Com o aumento do nümero de carbonos, aumenta a retenção do solvente na bicamada com o consequente aumento da capacitância e diminuição da espessura. Haja visto que 
a bicamada plana pode ser pensada como um capacitor plano infinito cuja capacitância é função inversa da distância en tre as placas, ou seja, da espessura da bicamada e função direta da constante dielétrica do meio entre as placas (Tien, $1974)$.

O problema representado pelo solvente na bicamada foi solucionado com a formação de bicamadas planas em ausência de solvente e pela simples aposição de duas monoca madas (Montal e Mueller, 1972). Essa bicamada é idêntica à membrana celular quanto a parâmetros como espessura e capacitância mas ainda bastante divergente quanto a parâmetros como resistência e condutāncia. Permite, todavia, uma possibilidade nova e ainda bastante inexplorada : a formação de bicamadas com proteínas inseridas, o que representa um passo bastante significativo no caminho da reconstituição de características isoladas de membranas naturais em sistemas artificiais.

Lipossomos provavelmente aproximam-se mais das estruturas prébióticas primitivas que, pela primeira vez, permitiram a compartimentalização (Goldacre, 1958) . Lipossomos são compostos por múltiplas lamelas fechadas e concên tricas de fosfolipides (Luzzati e Husson, 1962; Stoeckenjus, 1962; Bangham e Horne, 1964; Bangham et al., 1965; Bangham, 1968). Podem ser formados por vários métodos. Preparações obtidas por agitação de um filme lipídico fino (Bangham et al., 1965; Kinsky, 1974), originalmente introduzidas por Bangham et al. (1965), têm sido utilizados para se medir pa râmetros de permeabilidade de vários íons e moléculas (Bang 
ham, 1968). Preparações obtidas por dispersão ultrasônica do lîpide seguida de filtração em gel têm permitido a obten Ção de populações uniformes compostas de apenas uma bicamada lipídica fechada (Huang, 1969). O mëtodo de agitação de Bangham é simples mas produz estruturas multilamelares de uma grande variedade de tamanhos. Como a maior parte do lí pide está presente na forma multilamelar, o volume sequestrado por mol de lípide (eficiência de incorporação) é rela tivamente baixo. O mētodo de sonicação seguido de filtraÇão em gel (Huang, 1969) produz vesículas uniformes e compostas de bicamadas únicas mas muito menores $-250 \mathrm{~A}^{\mathrm{O}}$ de diâa metro - que a maioria das estruturas biológicas. O método de injeção de solução etanólica do fosfolípide em solução aquosa (Batzri e Korn, 1973; Kremer et al., 1977) produz ve sículas similares em tamanho às preparações obtidas por ultrasom mas possui uma desvantagem : a presença do ālcool na preparação. Métodos mais recentes envolvendo a extrusão de lipossomos através de membranas de policarbonato (Olson et al., 1979; Szoka et al., 1980) ou a introdução de um tampão aquoso em uma solução de lípide em éter (Szoka e Papahadjopoulos, 1978; Schieren et al., 1978) produzem lipossomos de tamanho mais definido que os de Bangham et al. (1965) mas requerem equipamento especial. Métodos mais elaborados de produzir vesiculas unilamelares pequenas $\left(150-500 \mathrm{~A}^{\mathrm{O}}\right.$ de diâ metro) como a diluição de micelas constituídas por detergen te e fosfolipide por filtração em gel ou diálise (Razin, 1972; Brunner et al., 1976; Rhoden e Goldin, 1979; Zumbueh1 e Weder, 1981) ou a injeção de uma dispersão lipídica atra 
vés de um pequeno orifício de uma prensa "French press" (Ba renholz et al., 1977, 1979; Hamilton et al., 1980), apesar de evitarem a degradação que pode ocorrer durante a disper são por ultrasom (Huang, 1969) ou introduzem detergentes no sistema ou tambëm requerem equipamento especial.

Um método ideal de produzir lipossomos deveria resultar em vesículas de tamanho uniforme, seria aplicável à maioria das misturas de lípideos e incorporaria eficiente mente ions, metabólitos e moléculas de elevado pêso molecular. O diâmetro das vesỉculas deveria estar na faixa de 0,1 a 1,0 micro para se assemelhar às membranas plasmāticas e resultar em elevada eficiência de incorporação. Lipossomos predominantemente unilamelares do tamanho de microssomos (0,1-1,0 micra de diâmetro) foram obtidos por vārios métodos : injeção de solução etérea dos lípides em soluções aquosas aquecidas acima da temperatura de ebulição do éter (Deamer e Bangham, 1976; Deamer, 1978; Shieren et al., 1978), inchamento lento de um filme lipídico (Reeves e Dowben, 1969, 1970), inchamento lento de proteína contendo filme lipíaico (Darszon et al., 1980) e a remoção da fase orgânica sob pres são reduzida em microemulsões "āgua em óleo" de lípides e tampão : evaporação de fase reversa (Szoka e Papahadjopou 1os, 1978). Esses métodos permitem a incorporação de macro moléculas nos lipossomos mas apresentam tambēm desvantagens como a dificuldade de se controlar a velocidade de injeção ou de hidratação ou a exposição do material a sex encapsula do a solventes orgânicos. 
ção dos lipossomos e a associação das molēculas lipĩdicas, Tanford (1980) aponta a predominância das interações hidrofóbicas entre as cadeias hidrocarbônicas dos lipídeos sobre a repulsão eletrostática e/ou estérica entre as cabeças polares como o fator principal.

Modelos estruturais adequados para os lipossomos devem considerar interações cauda-cauda, cabeça-cabeça e cabeça-cauda. O modelo de Marcelja (Marcelja, 1974a; 1974b) leva em conta todas as forças físicas atuantes entre as moléculas que constitutem a bicamada lipossomal : a energia intramolecular da cadeia, as atrações intermoleculares de van der Waal's entre as cadeias vizinhas e ainda, interações eletrostāticas, hidrofóbicas e estēricas. A partir desse modelo, parâmetros de ordem para cada segmento carbônico da cadeia alquila podem ser calculados (Schindler e Seelig, 1975) e comparados com os parâmetros de ordem determinados por ressonância magnética nuclear de deutério em lípides deu terados seletivamente (Seelig e Seelig, 1974). As coincidências entre os parâmetros calculados e os determinados ex perimentalmente sugerem que o modelo de Marcelja é adequado para descrever as estruturas dos Iipossomos. Topologia e dinâmica de lípides em membranas foram recentemente revistas na literatura (van Deenen, 1981; Israelachvili et al., 1980; Büldt e Wohlgemuth, 1981; Seelig e Seelig, 1980).

Com base em argumentos geomētricos, a formação de lipossomos parecia requerer moléculas contendo duas cadeias alquila sendo que moléculas com apenas uma cadeia alquila associavam-se somente na forma micelar (Israelachvili 
et al., 1976). Todavia, vesĩculas estáveis constituídas por anfifỉlicos de cadeia única já foram obtidas (Hargreaves e Deamer, 1978; Okahata e Kunitake, 1980). Assim, a formação de uma bicamada estável è um fenômeno complexo ainda pouco compreendido.

Um aspecto comum a todos os fosfolípides de membrana é a existência de uma transição reversível dependente de temperatura em que as cadeias hidrocarbônicas do fosfolípide passam de um estado ordenado, cristalino para um estado mais fluỉdo e desordenado (Sturtevant, 1974; Lee, 1977a, 1977모 ). A temperatura em torno da qual essa transiÇão ocorre è a chamada temperatura de transição de fase (TC). Abaixo da Tc, os lípides encontram-se em um estado altamente ordenado, com as cadeias alquila em conformação "trans". Acima da TC, passam ao estado líquido-cristal consequente de rotações "gauche" e da formação de "kinks" e caracterizado por uma fluidez bem maior que a do estado gel (Lee, 1977â). A transição da fase gel para a líquido-cristal tem sido observada através de diversos métodos como ressonância magnética nuclear, ressonância magnética eletrônica, espectroscopia Raman, difração de raios $\mathrm{x}$, calorimetria diferencial, determinação de viscosidade, espalhamento de luz e me dição de indices de refração (Lee, 1977ạ; 1977ㅁ).

Lecitinas hidratadas sintéticas (dimiristoil e dipalmitoil-lecitina) passam por duas transições térmicas : uma pré-transição numa faixa de temperatura relativamente larga e de baixa entalpia seguida de uma transição abrupta e de entalpia bem maior (Chapman, 1975). Embora a mudança 
de estrutura associada à transição principal seja relativamente conhecida (Chapman, 1967, 1976; Luzzati, 1968a,1968b; Ladbrooke e Chapman, 1969; Sheetz e Chan, 1972; Suurkuusk

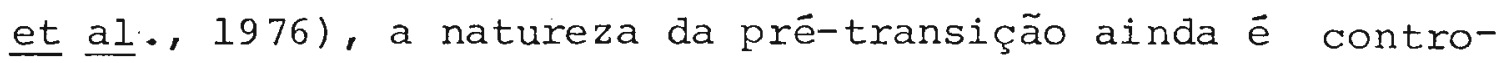
versa.

Janiak et $\underline{\text { al }}$. $(1976,1979)$ investigaram sistematicamente o comportamento de lecitinas sintēticas em função da temperatura através de difração de raios $\mathrm{x}$ e de calo rimetria diferencial com o objetivo de caracterizar as estruturas associadas à pré-transição. Propuseram que, abaixo da pré-transição, as cadeias hidrocarbônicas estariam com pletamente estendidas e inclinadas em relação ao plano da bicamada. Com o aumento da temperatura haveria uma diminui ção desse ângulo de inclinação até uma inclinação mínima oor respondente à temperatura de prē-transição, estando a bicamada distorcida por ondulações periódicas. Outros autores mostram, através de ressonância magnética nuclear de deutério ou de prótons, que a cabeça polar pode se rearranjar na pré-transição (Salsbury et al., 1971; Oldfield et al., 1971; Sheetz e Chan, 1972). Dados mais recentes, todavia, indicam que a cabeça polar não se rearranja durante a pré-transição (Gally et al., 1975). Estudos de fluorescência (Jacobson e Papahadjopoulos, 1975) mostram que a pré-transição altera significantemente o arranjo das cadeias alquila. Re centemente, Takemoto et al. (1981) obtêm pré-transição em lipossomos multilamelares mas não a obtêm em unilamelares sugerindo que a pré-transição estaria relacionada às intera ções entre as bicamadas concêntricas de cada lipossomo (mul tilamelares). 
Assim, alterações de estrutura lipossomal decorrentes de variação de temperatura estão apenas parcialmente definidas. Alterações funcionais de lipossomos por efeito de temperatura serão discutidas apōs a apresentação das propriedades funcionais dos lipossomos a dada temperatu彑 ra.

Do ponto de vista funcional, lipossomos permitem a obtenção de cinéticas de transporte de vārias substân cias, medindo-se a taxa de aparecimento de um marcador radioativo no meio externo (Bangham et $\underline{\text { al } ., ~ 1965 ; ~ P a p a h a d j o ~-~}$ poulos et al., 1971). Podem ser formados em uma solução aquosa contendo o marcador radioativo e, em seguida, centrifugados, filtrados em gel ou dializados para separação entre marcador livre e marcador incorporado.

A base de um outro método de medição de permeabilidades relativas de lipossomos a vārios solventes é o inchamento ou encolhimento lipossomal em decorrência de gra dientes osmóticos previamente estabelecidos (Bangham et al., 1967; Katchalsky e Curran, 1967; Sogor e Zull, 1975). Alterações na absorbância devidas a alterações nas propriedades de espalhamento de luz de suspensões de fosfolípides em àgua são inversamente proporcionais ao volume englobado pelos lipossomos (Rendi, 1965, 1967; Bangham et al., 1967). Através desse método, permeabilidades relativas de lipossomos constituídos por lecitina e ácido fosfotídico (96:4) pu deram ser estimadas (Bangham et $\underline{\text { al }}$. , 1967) para várias subs tâncias neutras ou iônicas. Em relação ao movimento de não eletrólitos (glicose, sacarose, eritritol, malonamida, uréia, 
propionamida, glicerol, etc.) a ordem de permeabilidades foi semelhante à de eritrócitos, o que pode ser encarado como a primeira indicação de que lipossomos de fosfolípides podiam mimetizar uma membrana biológica em um aspecto funcional importante. Entretanto, quanto ao movimento de eletrólitos, preparações de lipossomos não resultaram mimetizạ. doras tão adequadas, uma vez que se mostraram impermeantes a váxios sais ( $\mathrm{NaCl}, \mathrm{KCl}, \mathrm{NaAc}) !$ Fluxos de ${ }^{4} 2_{\mathrm{K}}^{+}$, por exemplo, são muitas ordens de magnitude inferiores aos que ocor rem através da maioria das membranas celulares (Bangham et al., 1965; Papahadjopoulos e Watkins, 1967). Alēm disso, uma das maiores limitações dos lipossomos como modelos é a impossibilidade de serem feitas medidas elétricas diretas (waggoner, 1976; Kornberg et al., 1972; Cafiso e Hubbell, 1978; Lelkes, 1979) como as que são possíveis em bicamadas planas (Tien, 1974; 1976, 1979; Jain, 1972; Jain e Wagner, 1980) - Resultam, todavia, bem adaptados para o estudo de interações entre lamelas de fosfolípides e proteínas em sis temas aquosos (Litman e Thompson, 1967) e mimetizam fenômenos celulares importantes como a adesão célula-célula e a fusão. Para citar um exemplo, recentemente foi descrito em nosso laboratório um modelo eficiente de fusão constituído por vesiculas de lecitina e albumina a pH 3,5 (Schenkman et al., 1981a, 1981ㅁ; Schenkman, 1981).

Um íon particularmente importante cuja permeação vem sendo estudada através de vários sistemas modelos de membrana é $\circ \mathrm{H}^{+}$. Gradientes de prótons ocorrendo através de membranas biológicas desempenham papel intermediārio em 
grande número de processos celulares como síntese de ATP, controle da divisão celular, manutenção de compartimentos ā cidos essenciais para atividade proteolitica de enzimas lisossomais e armazenamento de catecolaminas em vesículas de secreção (Gerson, 1978; Gillies e Deamer, 1979; Racker, 1972; Burton, 1975; Gerson e Burton, 1977; Gillies e Deamer, 1979; Mitchell, 1966; Jagendorf, 1975; Pick et al., 1974; Henning, 1975; Johnson e Scarpa, 1976; Toll e Howard, 1978).

Em organelas isoladas como mitocôndrias e cloroplastos esses gradientes são quantificāveis através de marcadores apresentando alguma propriedade mensurável variante com o pH como emissão de fluorescência ou absorção de um dado comprimento de onda (Rottenberg, 1979). Todavia, o maior problema metodológico que existe na utilização de mar cadores è a interação marcador-membrana que varia com as condições experimentais. Alëm disso, dificilmente pode-se aplicar essas técnicas a sistemas reconstituídos nos quais - volume do compartimento aquoso interno é geralmente muito menor que o volume interno típico de organelas (Watts et al. 1978).

Recentemente, alguns autores mediram permeabilidades a $\mathrm{H}^{+} / \mathrm{OH}^{-}$em vesículas unilamelares grandes de fosfo lípides (Nozaki e Tanford, 1981; Nichols et al., 1980; Nichols e Deamer, 1980) obtidas por injeção de solução de fos folípide em ēter (Deamer e Bangham, 1976) ou por remoção de detergente em soluções micelares mistas de fosfolipide e oc tilglicosídeo (Mimms et al., 1981). Chegaram, entretanto, a conclusões bastante divergentes. Nozaki e Tanford (1981) 
obtiveram permeabilidades cinco ordens de magnitude abaixo da obtida por Nichols e Deamer (1980), ou seja, permeabili dades a $\mathrm{H}^{+} / \mathrm{OH}^{-}$comparáveis às obtidas para outros cátions e ânions pequenos. Concordando com Nichols e Deamer (1980), Clement e Gould (1981) obtiveram permeabilidades elevadas a $\mathrm{H}^{+}$em vários tipos de vesículas fosfolipidicas (vesículas sonicadas de fosfatidilcolina, lipossomos multilamelares de asolectina e vesículas de asolecitina preparadas por diluição de detergente (Racker, 1973; Racker e Hinckle, 1974)). Por outro lado, Gutknecht e Walter (1981) chegaram a conclusões bastante similares às de Nozaki e Tanford (1980) à partir de estudos com bicamadas fosfolipídicas pla nas contendo decano. Uma vez que a própria ordem de grandeza da permeação de $\mathrm{H}^{+}$em bicamadas fosfolipỉdicas é ainda bastante controversa, a grande multiplicidade de mecanismos propostos na literatura para essa permeação è compreensível. Clement e Gould (1980) demonstraram uma cinética bifásica para a acidificação do compartimento aquoso interno após uma rápida queda do pH externo e interpretaram a etapa rāpida como devida a um influxo rāpido de $\mathrm{H}^{+}$ eletricamente não compensado e a etapa lenta como devida a um influxo de $\mathrm{H}^{+}$eletricamente compensado por saida de um cātion, supostamente o $\mathrm{K}^{+}$. Nichols et al. (1980), com base na elevada permeabilidade de bicamadas fosfolipídicas à āgua (Bangham et al., 1967; Hanai e Haydon, 1966; Cass e Finkelstein, 1967) e na presença de ãgua na bicamada (Schâ tzberg, 1965; Black et al., 1948; Bonner e Choi, 1975; Men ger et $\underline{\text { al }} \cdot$, 1978), propuseram transferência de $\mathrm{H}^{+} / \mathrm{OH}^{-}$ao 
longo de sēries de moléculas de āgua ligadas por pontes de hidrogênio atravēs de rearranjo dessas pontes. Prótons ou hidroxilas ou ambos interagiriam com aglomerados dessas moléculas ligadas de água na bicamada lipídica de forma a serem transferidas atravēs da bicamada por rearranjos de pontes de hidrogênio, analogamente ao transporte de $\mathrm{H}^{+} / \mathrm{OH}^{-}$em água e no gêlo. Nozaki e Tanford (1981) sugerem que a permeabilidade aparente medida através de efluxo de $\mathrm{H}^{+}$em vesi culas unilamelares grandes de fosfolípides seria a soma das contribuições do movimento de $\mathrm{H}^{+}$e da espécie não carregada ( $\mathrm{HCl}$ ou $\mathrm{HNO}_{3}$ ) em equilíbrio com o ânion da solução. A contribuição dominante seria a devida à espécie não carregada e o coeficiente de permeabilidade ao $\mathrm{H}^{+}$per se não seria maior que o usualmente obtido para outros cátions pequenos. Assim, o transporte resultante de prótons se daria principalmente por moléculas neutras de ácido (e.g., HCl) através da membrana e não, por difusão de $\mathrm{H}^{+}$per se. Todavia, outros autores (clement e Gould, 1981), utilizando ácidos de ânions impermeantes como $\mathrm{OH}_{2} \mathrm{SO}_{4}$, mostraram que alterações do $\mathrm{pH}$ intravesicular totalmente análogas às decorrentes de alteração do pH externo com ácidos de ânions permeantes (HCl, por exemplo) eram obtidas demonstrando que a permeação de prōtons não poderia ser atribuída principalmente a fluxos eletroneutros de $\mathrm{HCl}$. Assim, em meio a toda essa controver sia em torno da permeação de $\mathrm{H}^{+}$, sistemas sintéticos artifí ciais como o constituído por moléculas de DODAC (Cloreto de dioctadecildimetilamonio), por exemplo, seriam particularmente promissores, visto que permitiriam estudar implica- 
Ções de carga superficial e de estrutura química sobre a permeação.

Efeitos de temperatura sobre as propriedades de barreira de lipossomos vêm sendo verificados principalmente atravēs de determinações de permeação de substâncias neutras ou iônicas. Em torno da Tc, as características de barreira das membranas lipĩdicas são profundamente alteradas (Ladbrooke e Chapman, 1969; Vaugham e Keough, 1974 ; Steim et al.., 1969; Martonosi, 1974; Verkleij et al., 1974). Estudos com lecitinas saturadas sintéticas mostraram que bi camadas de dimiristoilfosfatidilcolina são excelentes barreiras tanto acima quanto abaixo da transição de fase tornando-se, entretanto, altamente permeantes a íons em torno da Tc (Haest et al., 1972; Blok et al., 1976). Um máximo de permeabilidade ao $\mathrm{Na}^{+}$foi observado por Papahadjapoulos, et al. (1973) no ponto médio da transição de fase. Van Dijck et $\underline{\text { al }}$. (1975) observaram um máximo de vazamento de $\mathrm{K}^{+}$em $1 \underline{i}$ possomos de dimiristoilfosfatidilcolina coincidente com o único do pico de absorção de calor correspondente à transição de fase registrado por calorimetria diferencial. Blok et al. (1976) mostram um drástico aumento da velocidade de permeação de água e de glicose em torno da Tc. Todos esses autores interpretam as alterações de permeabilidade como de correntes da coexistência de duas fases durante a transição, - que levaria à formação de poros estatísticos ou de regióes de desordem nos limites entre os domínios sólidos e líquidos por onde a permeação seria facilitada.

O fato de se procurar mimetizar funções de mem 
brana em sistemas artificiais conduziu não apenas a uma melhor compreensão dessas funções como tambēm a sistemas novos que se prestaram a estudos em várias outras áreas como fotoquímica, transdução de energia e catālise de reações químicas. Vesículas formadas a partir de detergentes sintê ticos são passiveis de serem investigadas sob vārios aspectos. Bicamadas fechadas foram obtidas por Gebicki e Hicks (1973, 1976) por agitação de filmes finos de ācido oleico e linoleico em tampões aquosos; resultaram, todavia, instāveis a pH's fora da faixa 6-8, não se concentraram por centrifugação e não retiveram substratos. Hargreaves e Deamer (1978) reportaram a formação de vesĩculas a partir de anfifilicos de cadeia única com 8 a 18 carbonos que se mostraram estáveis em uma faixa ampla de pH's, comportaram-se como osmômetros ideais e encapsularam solutos. Haletos de dialquildimetilamonio (Kunitake et al., 1977; Kunitake e okahata, 1977ạ; Deguchi e Mino, 1978; Kunitake e Okahata, $1977 \underline{b} ;$ Kunitake e Sakamoto, 1978; Nagamura et al., 1978; Ka jiyama et al., 1979; Henglein et al.., 1978; Czarniecki, 1979; Cuccovia et al., 1979), dialquilfosfato de sōdio (Mortara et al., 1978), sulfonato, carboxilato (Kunitake e Okahata, 1978) e ainda detergentes zwitteriônicos (Kunitake e Yamada, 1978) tambëm formam estruturas vesiculares.

A formação de vesículas e não, de estruturas lamelares, parece depender tanto da natureza do detergente quanto do comprimento da cadeia alquila. Brometos de didodecildialquilamonio, didodecil e dioctadecilsulfonatos, decil e didodecilfosfatos formam vesículas ao passo que seus 
homólogos de cadeia mais longa formam estruturas lamelares (Kunitake et al., 1977; Kunitake e okahata, 1978).

o método mais comumente utilizado para a forma ção de vesículas de detergente consiste na dispersão ultrasônica do mesmo (Kunitake et al., 1977; Kunitake e Okahata,

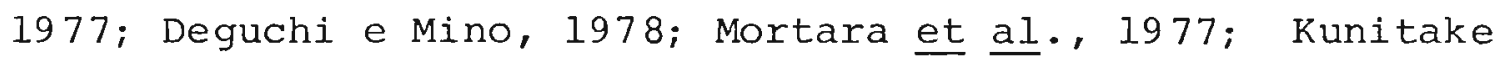
e Okahata, 1978; Okahata e Kunitake, 1979; Kunitake et al., 1979; Czarniecki e Breslow, 1979; Sudhölter et al., 1980 ; Kunitake e Okahata, 1980; Okahata e Kunitake, 1980; Murahami et al., 1980; Baumgartner e Fuhrhop, 1980; Regen et al.,

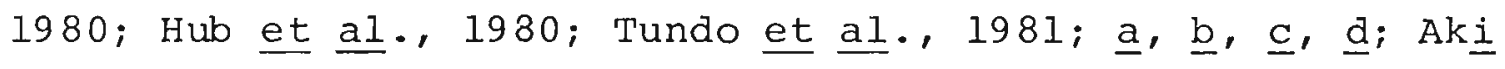
moto et al., 1981; O'Brien et al., 1981; Bader et al.,1981; Regen et al., 1981; Kunitake et al., 1980a, b; Nagamura et al., 1981). Assim, em decorrência do método de formação, a maior parte das vesículas obtidas são vesículas pequenas (250-300 $\mathrm{A}^{\circ}$ de diâmetro). Curiosamente, ainda não foram tes tados outros métodos disponíveis que resultassem na formação de vesículas grandes de detergente. Além disso, talvez em decorrência da inexistência desse tipo de sistema-modelo (vesículas grandes de detergente), a caracterização do sistema modelo existente (vesículas pequenas) em termos de pro priedades funcionais de membrana como transporte de ions e substâncias neutras, incorporação de vārios substratos, manutenção de gradientes eletroquímicos de vārias substâncias e outras ou em termos de propriedades fisicas como transição de fase, forma, dimensões, homogeneidade ou heterogenei dade da população, estabilidade frente a pH e a sais e outros, ainda é completamente deficiente. As caracterizações 
de vesículas de detergente existentes na literatura são extremamente pobres quando comparadas às existentes para vesí culas de fosfolipideos. Basta mencionar que a maioria dos trabalhos de caracterização de vesículas de detergente apre senta apenas uma micrografia eletrônica dos mesmos (Kunitake et al., 1977; Kunitake e Okahata, 1977; Deguchi e Mino, 1978; Okahata e Kunitake, 1979; Kunitake et al., 1979; Sudhölter et al., 1980; Okahata e Kunitake, 1980; Murakami et al., 1980; Baumgartner e Fuhrhop, 1980; Regen et al., 1980; Hub et al., 1980; Akimoto et al., 1980; O'Brien et al., 1981; Kunitake et $\underline{\text { al. }}$, 1980a, b $)$ sendo que uma minoria inclui tam bēm dados de resposta osmótica (Gebicki e Hicks, 1976), de incorporação de substrato (Gebicki e Hicks, 1976; Mortara et

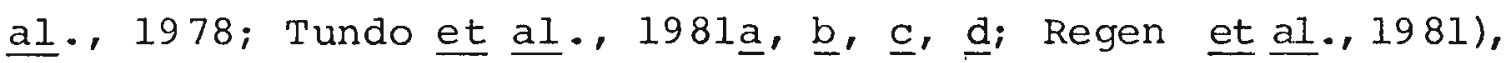
de calorimetria diferencial (Kunitake e Okahata, 1980) e de filtração em gel (Mortara et al., 1978; Tundo et al., 1981 $\underline{a}_{\text {}}$ $\underline{b}, \underline{c}, \underline{d})$.

o sistema-modelo constituído por vesículas pequenas de detergente que, aparentemente, é o sistema mais investigado e melhor caracterizado é o sistema composto pelo cloreto de dioctadecildimetilamônio (DODAC) (Fendler,1980). Essas vesículas obtidas por dispersão ultrasônica apresenta riam as seguintes propriedades : 1) seriam maiores que as vesículas de fosfatidilcolina obtidas por ultrasom e teriam $300 \mathrm{~A}^{\mathrm{O}}$ de diâmetro (Deguchi e Mino, 1978; Hermmann e Fendler, $1979)$; 2) apresentariam uma prë-transição a $30^{\circ} \mathrm{C}$ e uma tran sição a $36^{\circ} \mathrm{C}$ (Kano et $\underline{\text { al.. }}$ 1979); 3) seriam osmóticamente a tivas mas instáveis em presença de $\mathrm{KCl}$ a partir de 0,1M 
(Kano et al., 1979); 4) reteriam aminoácidos zwitteriônicos em seu interior com um mínimo de vazamento (Tranet al.,1978); 5) seriam estáveis em ampla faixa de pH's $(2,0-12,0)$ (Fendler, 1980). Partindo dessas características, vesículas de DODAC obtidas por ultrasom seriam mimetizadores de membranas relativamente adequados. Todavia, a caracterização detalhada das propriedades funcionais e dinâmicas do sistema, ou seja, a determinação de permeabilidades do sistema a várias substâncias neutras ou iônicas seria ainda de importân cia fundamental para se poder decidir sobre a validade do modelo como mimetizador de membrana.

Desde 1978, nosso grupo vem se preocupando com vesículas de DODAC, principalmente sob o ponto de vista catalítico (Cuccovia et al., 1979, 1982). Várias incongruências com a literatura vêm, desde então, sendo observadas. Politi, por exemplo, verificou pronunciada instabilidade des sas vesículas frente a $\mathrm{pH}^{\prime} \mathrm{s}$ básicos (dados não publicados). Cuccovia, observou precipitação das mesmas em faixas de con centração de $\mathrm{KCl}$ muito inferiores à reportada por Fendler $(0,1 M)$. Finalmente, neste trabalho, mostramos que vesículas de DODAC obtidas por ultrasom são osmóticamente não res ponsivas a gradientes de sacarose e que a presença de sal em concentrações tão baixas quanto 10-15 mM é crítica para a estabilidade do sistema.

Este trabalho, que tinha inicialmente o objeti vo de estudar transporte e permeação de substâncias neutras ou iônicas em vesículas de DODAC obtidas por ultrasom, terminou por demonstrar a inadequação dessas últimas para tal 
tipo de estudo e por propor um novo sistema-modelo no qual propriedades funcionais podem ser convenientemente estudadas : o sistema constituído por vesículas grandes de DODAC. Essas vesículas possuem $0,51 \mu$ de diâmetro externo médio, são capazes de incorporar $9,7 \pm 1,31 / \mathrm{mol}$, comportam-se como osmô metros em vārias condições e possuem uma transição de fase gel para Iíquido-cristal extremamente nítida. Em contraste com o sistema constituído por vesículas sonicadas, vesículas grandes de DODAC são propostas como um modelo sintētico adequado de membrana. Adicionalmente, extendendo-se o méto do de obtenção de vesículas grandes de DoDAC por injeção de solução clorofórmica desse detergente em āgua, foram obtidas vesiculas grandes de dicetilfosfato de $\mathrm{Na}^{+}$. Dessa forma, abrem-se perspectivas de estudos de transporte de vārios substratos em sistemas sintēticos adequados (aqueles a presentando eficiências elevadas de incorporação) e tornase possivel aplicar métodos disponíveis para fosfolípidesem sistemas modelo constituídos por anfifílicos sintéticos. 
MATERIAL E METODOS

A purificação e anālise (Cuccovia et al., 1979) do Herquat 2HT-75 (Herga Indústrias Químicas do Brasil) resultou em uma mistura de sais de amônio quaternārio com a se guinte composição com relação ao comprimento das cadeias alquila : 85응-Cl8, 15 $\mathrm{n}-\mathrm{Cl} 6$ e traços de n-Cl4. Assim, vamos nos referir a essa mistura como DODAC (cloreto de diocta decildimetilamonio) dado o elevado percentual deste componen te na mesma.

Sephadex G-25 (fine) foi proveniente da Sigma (St. Louis, Mo.).

$$
\left({ }^{14}\right. \text { C)-sacarose (Schwarz-Mann, Orangeburg, N.Y., }
$$
atividade específica de $480 \mathrm{mC} / \mathrm{mM}$ ) teve sua pureza radioquímica controlada através de cromatografias em papel Whatmann no 1 utilizando-se n-butanol/etanol/água (52 : 32 : 16) como fase móvel. $R_{E} S$ obtidos corresponderam ao valor fornecido pela Schwarz-Mann : 0,19 .

Todos os outros reagentes utilizados possuiam grau analitico de pureza. Agua deionizada, destilada duas vezes em vidro foi usada em todos os experimentos.

Concentrações de DODAC foram determinados por microtitulações de $\mathrm{Cl}^{-}$de acordo com o processo descrito por Schales e Schales (1949). 
1. PREPARAÇÃo DE VESICULAS PEQUENAS DE DODAC.

Vesículas pequenas de DODAC foram preparadas por sonicação, a temperaturas entre $60-80^{\circ} \mathrm{C}$, de $60 \mathrm{mg}$ de DODAC em $10 \mathrm{ml}$ de solução aquosa usando-se a sonda de um Cell Disrupter Virsonic - Model 150 operado a 90W nominais durante 10 minutos. A dispersão assim obtida foi centrifugada min.; $10000 \mathrm{~g} ; 22^{\circ} \mathrm{C}$ ) para se precipitar partículas de titânio liberadas pela sonda durante a sonicação. O sobrenadante cor responderá à preparação referida como vesĩculas sonicadas de DODAC.

2. PREPARAÇÃO DE IIPOSSOMOS GRANDES DE DODAC POR VAPORIZAÇÃO $\mathrm{DE} \mathrm{CHCl}_{3} \cdot$

O método de vaporização de éter descrito por Deamer e Bangham (1976) para obtenção de vesículas unilamela res grandes de fosfolipideos foi adaptado para o DODAC. 1,0 ml de uma solução 0,02M de DODAC em clorofórmio foi injetado a uma velocidade aproximada de $0,2 \mathrm{ml} / \mathrm{min}$. em $4,0 \mathrm{ml}$ de uma so I ução aquosa termostatizada a $70,0 \pm 0,5^{\circ} \mathrm{C}$ e borbulhada com argônio para se facilitar a vaporização do clorofórmio. A montagem experimental é mostrada na Figura l. Alíquotas (lml) da dispersão assim obtida foram filtradas através de uma coluna de Sephadex G-25 (1,8 X 14,0 cm) previamente saturada com essa mesma dispersão de DODAC. Apenas recuperações de DODAC superiores a 90\% foram consideradas. Frações eluídas juntamente com o volume vazio dessas colunas serão referidas como 
lipossomos grandes de DODAC. A anālise quantitativa de clo rofórmio nos lipossomos grandes de DODAC (Snell e Snell, 1937) revelou porcentagens de $\mathrm{CHCl}_{3}$ inferiores a $0,5 \mathrm{~mol} \div(100 \mathrm{X}$ no de moles de $\mathrm{CHCl}_{3} /$ (n) de moles de $\mathrm{CHCl}_{3}+$ no de moles de DODAC ) ) .

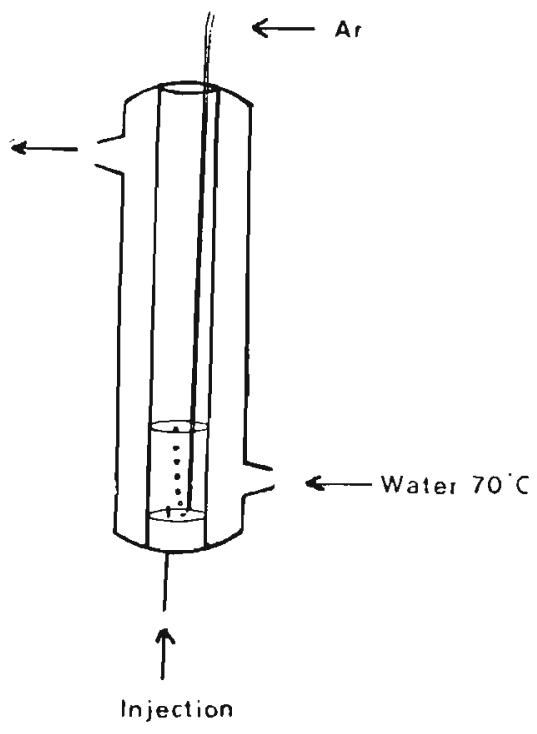

FIGURA I - Montagem experimental para preparação de lipossomos grandes de DODAC. A injeção da solução clo rofórmica é feita através de uma agulha hipodérmi ca fina. A solução aquosa é mantida aquecida e gitada durante e logo após a injeção.

3. MICROSCOPIA ELETRONICA DE LIPOSSOMOS GRANDES DE DODAC.

Volumes iguais de molibdato de amônio 2 응 ou ace tato de uranila $1 \%$ e lipossomos grandes de DODAC foram colocados sobre telas de cobre recobertas com um filme de parlodio. Com auxílio de uma lupa e de um papel de filtro, 30 se gundos após a mistura dos lipossomos com o corante eletrôni- 
co, o excesso de Iíquido sobre a tela foi retirado. Uma vez evaporada toda a água, a tela foi observada ao microscópio eletrônico (Zeiss - EM 952, operado a $60 \mathrm{kV}$ ) em diversos au mentos e fotografada.

4. DETERMINAÇÕES DE VOLUME DO COMPARTIMENTO AQUOSO INTERNO (V) •

Dispersões de DODAC (vesiculas sonicadas ou li possomos grandes) foram preparadas em āgua contendo $\left({ }^{14} \mathrm{C}\right)$-sa carose. Alíquotas dessas preparações $\left(V_{A} m l\right.$ de uma dispersão contendo $n$ milimoles de DODAC) foram filtradas atravēs de uma coluna de Sephadex G-25 (1,8 x 14,0 cm). A partir dos perfis de eluição (ver Fig. llA em "Resultados", para um e xemplo) pôde ser calculada uma porcentagem de incorporação (응 inc.) igual a

$$
\therefore \text { inc. }=\frac{\mathrm{CPM}(\mathrm{Vo})}{\mathrm{CPM}(\mathrm{Vi})} \times 100
$$

onde CPM (Vo) é a radioatividade eluída em torno do volume vazio Vo é CPM (Vi) é a radioatividade eluỉda em torno do volume interno Vi da coluna. Assim, se lo0ml de dispersão incorporam \% inc. então $\mathrm{V}_{\mathrm{A}} \mathrm{ml}$ irão incorporar $\frac{\mathrm{V}_{\mathrm{A}} \mathrm{X} \text { \% inc. }}{100}$

em n milimoles de DODAC. Portanto, o volume incorporado por mol de DODAC serā :

$$
\mathrm{V}=\frac{\mathrm{V}_{\mathrm{A}} \mathrm{X} \% \text { inc. }}{100} \times \frac{1}{\mathrm{n}}
$$

Introduzindo (1) em (2), temos:

$$
\mathrm{V}=\frac{\mathrm{V}_{\mathrm{A}}}{\mathrm{n}} \times \frac{\mathrm{CPM}(\mathrm{VO})}{\mathrm{CPM}(\mathrm{Vi})}
$$


Como $\mathrm{n} / \mathrm{V}_{\mathrm{A}}$ é a concentração de DODAC na amostra colocada no topo da coluna, o volume do compartimento aquoso interno $V$, em $1 / \mathrm{mol}$, pode ser tomado como :

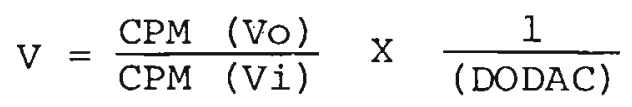

onde (DODAC) è a concentração de DODAC na amostra colocada no topo da coluna (em M).

Controles de adsorção externa da $\left({ }^{14} \mathrm{C}\right)$-sacarose à bicamada de DODAC foram feitos adicionando-se $\left({ }^{14} \mathrm{C}\right)$-sa carose a vesículas de DODAC já formadas e procedendo-se então à determinação de (DODAC) e de o inc. para o cálculo de $\mathrm{V}$ conforme explicitado acima.

5. DETERMINAÇÕES DE RADIOATIVIDADE EM AMOSTRAS AQUOSAS.

Amostras contendo marcadores radioativos $(0,1$ a $0,5 \mathrm{ml}$ ) foram misturadas com $5 \mathrm{ml}$ de líquido de cintilação constituido por 2,5-difeniloxazol (4g), 2,2'-p-fenilembis (5-feniloxazol) $(0,1 \mathrm{~g})$, tolueno (1 1) e Triton $x-100(0,51)$, determinando-se a radioatividade das amostras em um espectrocintilômetro Beckman Ls-250.

6. DETERMINAÇÕES DE PROPRIEDADES OSMOTICAS.

Dispersões de DODAC foram adicionadas a soluções aquosas de $\mathrm{KCl}$ ou de sacarose lou soluções de $\mathrm{KCl}$ ou de sacarose foram adicionadas a dispersões de DODAC) em cubeta de quartzo de $1 \mathrm{ml}$. Alterações de absorbância decorren 
tes de mudanças no espalhamento da dispersão foram registra dos em função do tempo utilizando-se um espectrofotômetro Cary-14 com o comprimento de onda fixo em $400 \mathrm{~nm}$ (para a dis persão obtida por injeção de solução clorofórmica de DODAC em água) ou em 280nm (para a dispersão obtida por sonicação). Os registros foram iniciados rotineiramente entre 610 segundos após a mistura (efetuada com agitador manual). A partir desses registros, foram calculados parâmetros como : 1) velocidade inicial de encolhimento $\left(\mathrm{V}\right.$ \%) $=\frac{I}{A o} \frac{\Delta \mathrm{A}}{\Delta t} \mathrm{X}$ 100 ; 2) recíproco da alteração total de absorbância $\left(\frac{1}{\Delta \mathrm{A}}\right)=$ $\left.\frac{1}{A f-A O} ; 3\right)$ extensão total de encolhimento $(S)=\left(\frac{1}{A O}-\frac{1}{A f}\right) x$ Ao $\mathrm{X} 100$ onde $\frac{\Delta \mathrm{A}}{\Delta t}$ representa o coeficiente angular inicial da reta tangente à curva absorbância versus tempo; Ao, a ab sorbância inicial; Af, a absorbância final.

Valores médios para esses parâmetros foram obtidos a partir de, pelo menos, duas cinéticas independentes e barras de êrro (desvio quadrātico médio) foram calculadas para cada valor médio.

A reversibilidade do efeito de alteração da ab sorbância com o tempo decorrente de gradientes osmóticos im postos aos lipossomos de DODAC foi testada. Aliquotas de lipossomos encolhidos com vârias concentrações de $\mathrm{KCl}$ foram misturadas com āgua e rapidamente homogeneizadas em cubeta de quartzo de $1 \mathrm{ml}$. Alterações de absorbância a $400 \mathrm{~nm}$ com o tempo foram então registrados em espectrofotômetro Cary-14. Tomando-se Ao como absorbância inicial dos lipossomos imediatamente após serem submetidos ao encolhimento, Af como 
absorbância final dos lipossomos encolhidos, A'o como absor bância inicial dos lipossomos encolhidos imediatamente após serem misturados com āgua e A'f como absorbância final dos lipossomos após a reversão do encolhimento, podemos conside rar que a diluição dos lipossomos encolhidos é igual a

$$
\text { DILUIÇÃO }=\frac{A f}{A^{\prime} O}
$$

O critērio utilizado para se averiguar a rever sibilidade do encolhimento foi comparar a absorbância final dos lipossomos encolhidos ( $A^{\prime} f$ ) corrigida para a diluição com a absorbância inicial dos lipossomos imediatamente após serem submetidos ao encolhimento (AO).

7. DETERMINAÇÕES DE TRANSIÇÃO DE FASE.

Absorbâncias (derivadas do espalhamento) de ve siculas sonicadas ou lipossomos grandes de DODAC foram registradas em função da temperatura em um espectrofotômetro cary-14 equipado com um porta cubetas termostatizável (acoplado a um banho circulante Haake E-12). A velocidade de aquecimento ou de resfriamento esteve, geralmente, entre 1$2^{\circ} \mathrm{C} /$ min.. Temperaturas foram medidas dentro da cubeta atra vēs de um termopar cobre-constantan conectado a um milivoltímetro. A resposta desse sistema medidor de temperatura é linear entre $0-100^{\circ} \mathrm{C}$ com um erro relativo inferior a $0,01 \%$.

8. EFEITOS DA TEMPERATURA SOBRE $v$ 응 $\mathrm{S}$.

$0,2 \mathrm{ml}$ de 1 ipossomos grandes de DODAC 4,96mM fo 
ram adicionados a $0,8 \mathrm{ml}$ de $\mathrm{KCl} 0,0304 \mathrm{M}$ em cubeta de quartzo de 1,0ml. Alterações de absorbância a $400 \mathrm{~nm}$ com o tempo fou ram então registradas em espectrofotômetro Cary-14 a várias temperaturas. A partir desses registros foram calculados $\mathrm{v}$ \% e S. Tanto os lipossomos quanto a solução de $\mathrm{KCl}$ foram pré-incubados à temperatura desejada antes de serem mistura dos para a obtenção dos registros de absorbância em função do tempo. A temperatura dentro da cubeta foi medida com o termopar cobre-constantan ao longo de cada registro de $a b-$ sorbância com o tempo apresentando variações sempre inferio res a $0,5^{\circ} \mathrm{C} . \mathrm{v} \%$ (velocidade inicial de encolhimento) foi tomada como correspondente à temperatura medida com o termopar imediatamente após a mistura dos lipossomos com a solução de $\mathrm{KCl}$. Já o parâmetro S (extensão total de encolhimento) foi tomado como correspondente à média das temperatụ ras medidas ao longo do registro de alteração da absorbância com o tempo.

9. DETERMINAÇÕES DE PERMEABILIDADES RELATIVAS.

$0,5 \mathrm{ml}$ de lipossomos grandes de DODAC preparados em $\mathrm{KCl} 19,5 \mathrm{mM}$ foram adicionados a $0,5 \mathrm{ml}$ de soluções 19,5 mM de $\mathrm{NaCl}$ ou KCl ou HCl ou sacarose. Alterações de absorbância com o tempo apōs uma rápida homogeinização da mistura foram, então, registradas em um espectrofotômetro Cary-14. 
10. DETERMINAÇð̃ES DE PERMEAÇÃO DE PROTONS.

Dois métodos foram utilizados, ambos empregando marcadores do compartimento aquoso intralipossomal que mudassem uma propriedade mensurável de acordo com $\circ \mathrm{pH}: 1$ ) mudança de fluorescência da 2 aminopiridina (2 AP) (Aldṛich, Milwaukee, USA); 2) mudança de cor de mistura de corantes indicadores de $\mathrm{pH}$ : azul de bromotimol $(\mathrm{AB})$ e verde de bromocresol (VB) (E. Merck, Darmstadt). Soluções $10^{-4} \mathrm{M}$ de $2 \mathrm{AP}$ em cubetas de fluorescência com tampa tiveram seus pH's ajustados para valores dentro da faixa de 2-12. Foram borbu lhadas ininterruptamente $\operatorname{com} \mathrm{N}_{2}$ e mantidas em atmosfera des se gás para se evitar quedas de pH decorrentes de solubilização de $\mathrm{CO}_{2}$ do ar. Espectros de excitação e de emissão de fluorescência dessas soluções de 2 AP foram obtidos em um fluorimetro Perkin-Elmer $\mathrm{MPF}-4$ a cada $\mathrm{pH}$ (Fig. 2).

A dependência da emissão máxima da fluorescência da 2 AP com o pH está na Fig. 3. Dessa Figura, um pk aparente de 6,85 pôde ser calculado, em excelente acordo com - valor de 6,86 reportado na literatura (Weistuch e Testa, 1968; Babiak e Testa, 1973). Observa-se uma queda de cerca de 50\% na intensidade de fluorescência relativa ao se passar de $\mathrm{pH}^{\prime}$ s inferiores para $\mathrm{pH}$ 's superiores ao valor do $\mathrm{pK}$ aparente (Ver Fig. 3). 


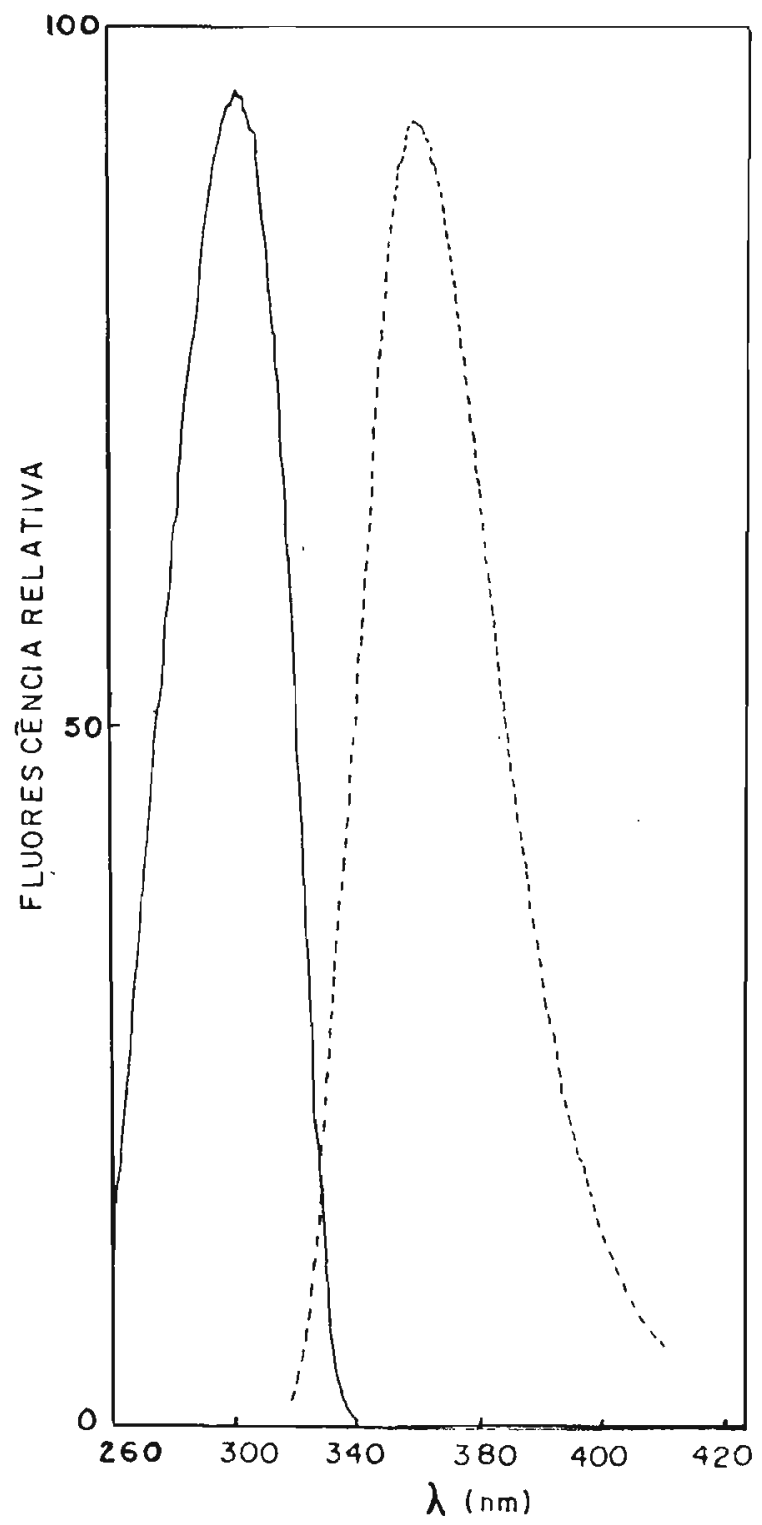
$\begin{aligned} \text { FIGURA } 2 \text { - Espectros da emissão }(---) & \text { e de excitação }\left(-\frac{}{\text { (a) }}\right) \\ & \text { da } 2 \text { aminopiridina }\left(10^{-4} \mathrm{M}\right) \text { em água a pH } 5,7 \text { (a- }\end{aligned}$ justado com $\mathrm{HCl}$ ) com comprimento de onda de exci tação e de emissão fixos em, respectivamente, $30 \overline{0}$ e $362 \mathrm{~nm}$. Modo "ratio". Fendas : $2 \mathrm{~nm}$, emissão ; $4 \mathrm{~nm}$, excitação. Sensibilidade $10 / 8$. 


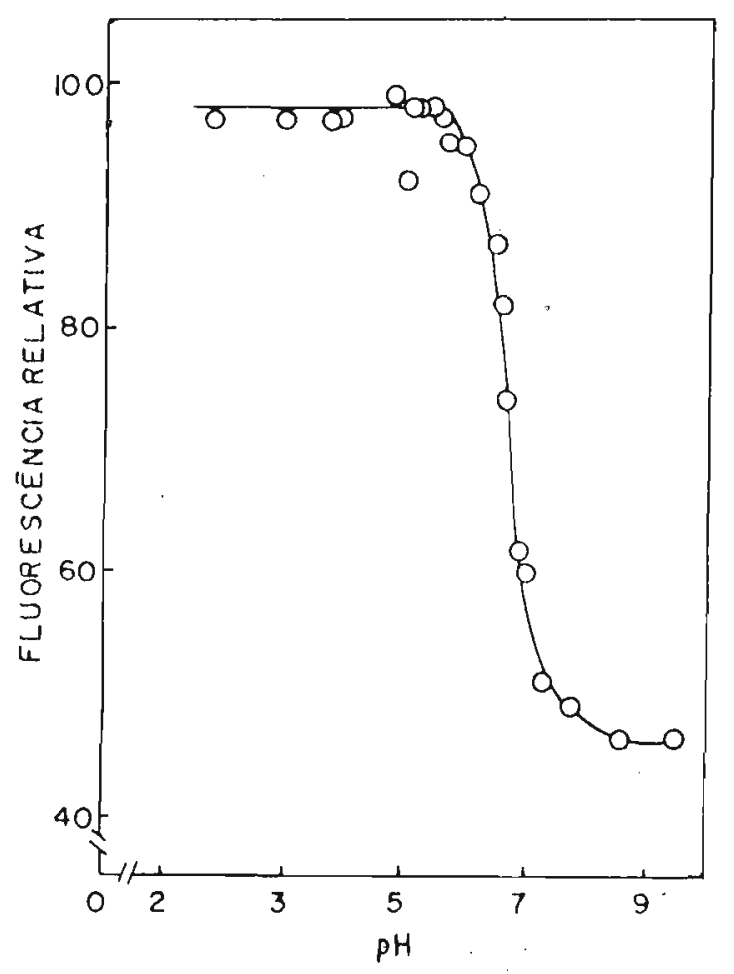

FIGURA 3 - Efeito do pH sobre a intensidade de fluorescência relativa da 2 aminopiridina $10^{-4} \mathrm{M}$. Comprimentos de onda de emissão e de excitação variáveis com o pH e selecionadds de forma a se obter intensidade máxima de fluorescência relativa.

A forma protonada da 2 AP possui frequências de emissão e de excitação diferentes da forma neutra. Ao se pasar de valores de $\mathrm{pH}$ inferiores ao do $\mathrm{pK}$ aparente para va lores de $\mathrm{pH}$ superiores ao do $\mathrm{pK}$ aparente, $\lambda$ excitação passa de 303 para $299 \mathrm{~nm}$ e $\lambda$ emissão passa de 362 para $353 \mathrm{~nm}$. Ver Figura 4 . 


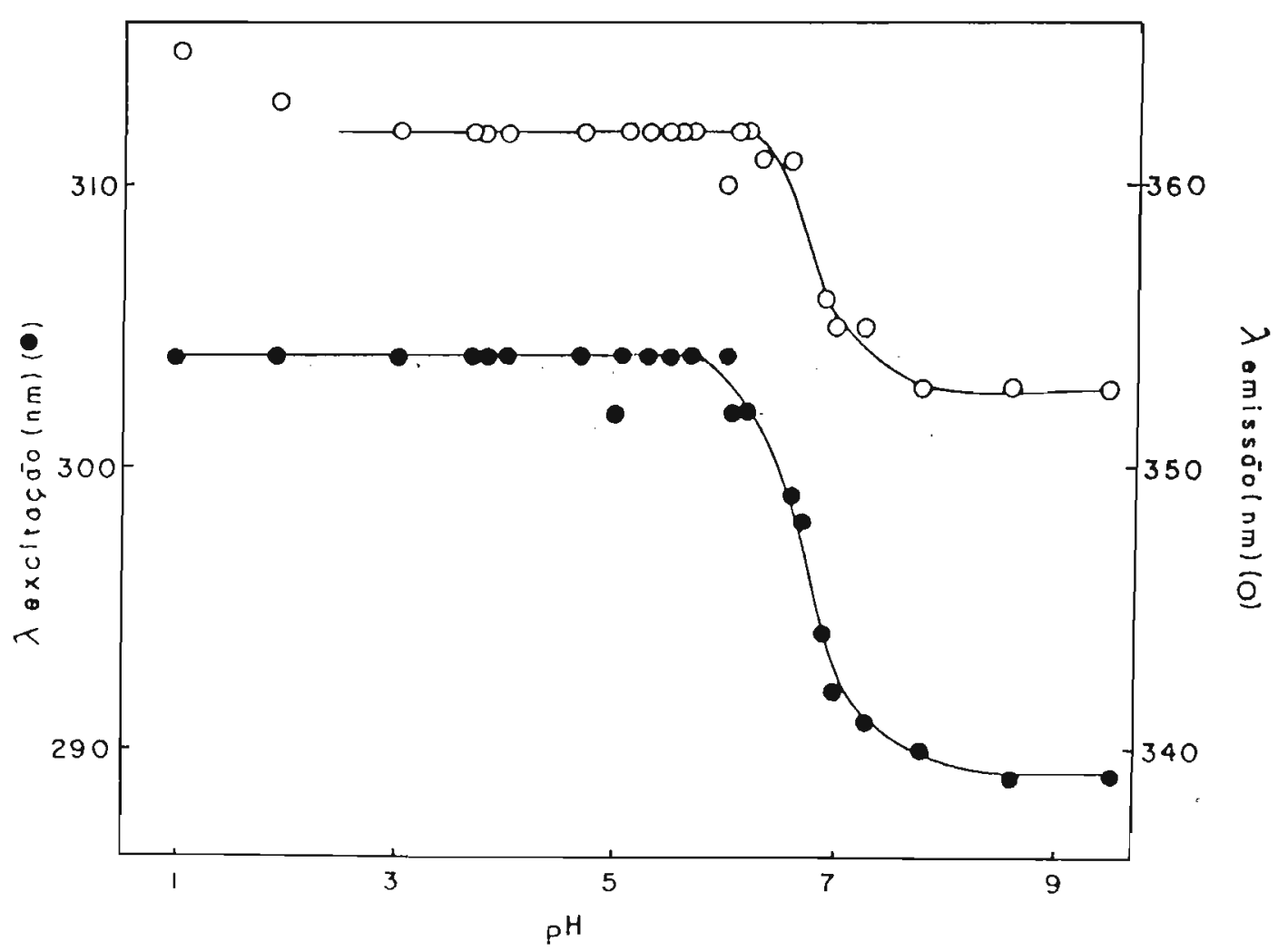

FIGURA 4 - Efeito do pH sobre os espectros de emissão e de excitação de fluorescência relativa da 2 aminopi ridina $10^{-4} \mathrm{M}$. $\lambda_{\text {exc }}$ e $\lambda_{\text {em }}$ : comprimentos de onda de excitação e de emissão correspondentes aos má ximos de intensidade de fluorescência relativa.

Vesículas sonicadas ou lipossomos grandes de DODAC foram preparados em solução de $\mathrm{HCl} 10^{-2} \mathrm{M}$ e de 2 AP, $10^{-2} \mathrm{M}$ e eluidas em Sephadex G-25 $(1,8 \times 15,0 \mathrm{~cm})$ com $\mathrm{HCl}$ $10^{-2} \mathrm{M}$. Para minimizar efeitos de espalhamento pela vesículas que poderiam interferir com as medidas de fluorescência, alíquotas de $0,5 \mathrm{ml}$ de cada fração coletada contendo vesículas foram levadas a $5 \mathrm{ml}$ com $\mathrm{HCl} 10^{-2} \mathrm{M}$ obtendo-se concentra ções finais de DODAC na cubeta entre 10 e $100 \mu \mathrm{M}, 4 \mathrm{ml}$ dessas frações diluídas contendo vesículas foram colocadas em cube 
tas de fluorescência, adicionadas de pequenas alíquotas de $\mathrm{NaOH}$ concentrado e rapidamente homogeinizadas para registro de alterações de fluorescência com o tempo em um fluorímetro Perkin-Elmer MPF-4 (excitação em $300 \mathrm{~nm}$ e emissão em 362 nm) . Porcentagens de incorporação de 2 AP foram determinadas pela relação entre a intensidade de fluorescência total coletada nas frações vesiculares e a intensidade de fluores cência total coletada em torno do volume interno da coluna.

Espectros de absorção de uma mistura de corantes indicadores de $\mathrm{pH}(\mathrm{AB} 0,1 \mathrm{mg} / \mathrm{ml}$ e $\mathrm{VB} 0,1 \mathrm{mg} / \mathrm{ml})$ apresentam dois máximos : um, a $410 \mathrm{~nm}$ (amarelo) e outro, a $610 \mathrm{~nm}$ (azul) sendo que o máximo do amarelo diminui e o do azul cresce com o aumento do $\mathrm{pH}$ (Fig. 5). O pK aparente do VB é 7,0 enquanto que o jok aparente do $\Lambda \dot{E} \bar{e} 4,7$ (Merck Index). Absorbâncias a $610 \mathrm{~nm}$ ou a $410 \mathrm{~nm}$ da mistura de corantes em tampão fosfato em função do $\mathrm{pH}$ são mostradas na Figura 6 .

Lipossomos grandes de DODAC contendo esses corantes indicadores de $\mathrm{pH}(\mathrm{AB} 0,1 \mathrm{mg} / \mathrm{ml}$ e $\mathrm{VB} 0,1 \mathrm{mg} / \mathrm{ml})$ foram obtidos injetando-se a solução clorofórmica usual de DODAC em $4 \mathrm{ml}$ da solução aquosa de corantes. Usando-se como branco uma cubeta de vidro contendo lipossomos grandes de DODAC preparados em água e como amostra, uma outra cubeta de vidro contendo lipossomos grandes de DODAC, de mesma concen tração, preparados em solução da mistura de corantes, monitorourse alterações de absorbância em espectrofotômetro Beckman-25 $\left(23^{\circ} \mathrm{C}\right)$ ao longo do tempo decorrentes da adição de ácido ou base a ambas as cubetas. O pH inicial dos 1ipossomos contendo a mistura de corantes lido em $\mathrm{pH}$ metro foi 


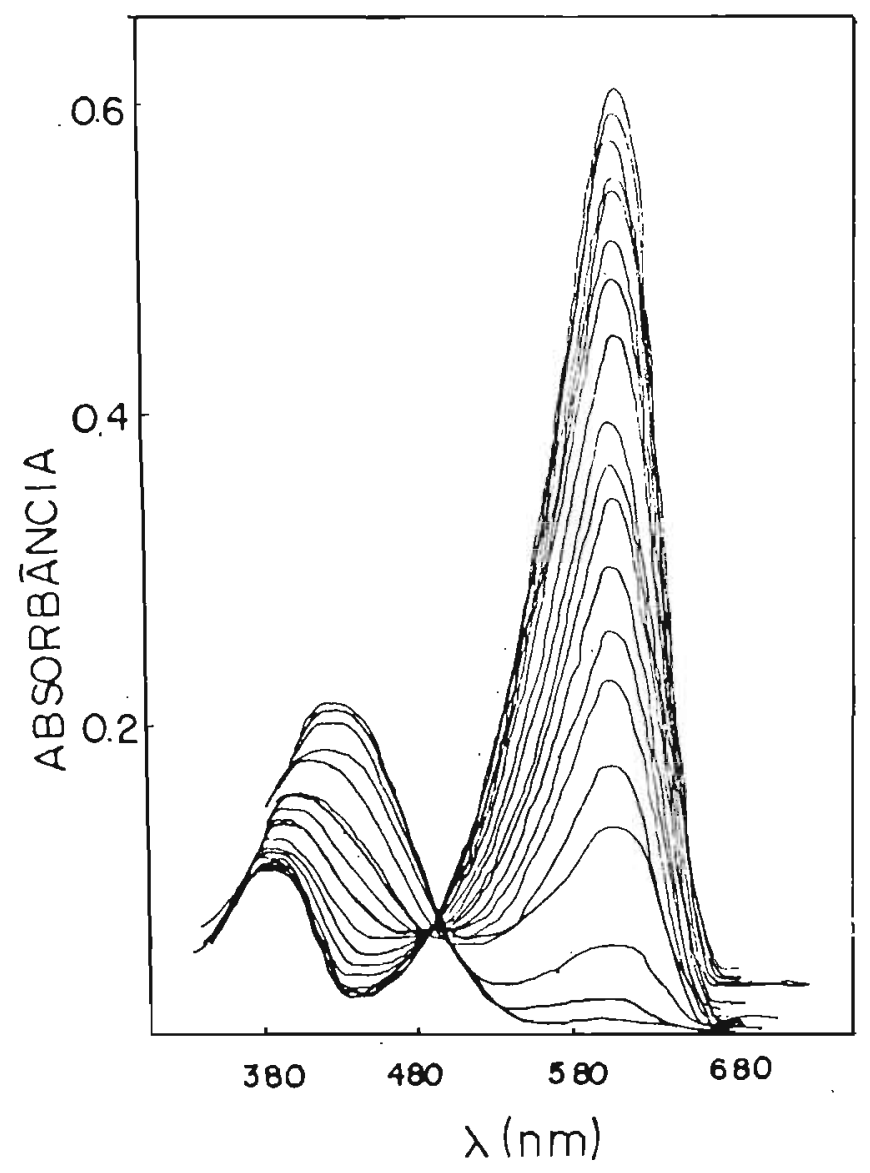

FIGURA 5 - Espectros de absorção de uma mistura de azul de bromotimol e verde de bromocresol, $0,1 \mathrm{mg} / \mathrm{ml}$ de cada corante, em tampão fosfato $10 \mathrm{~mm}$, em função do comprimento de onda. Diferentes espectros cor respondem a diferentes $\mathrm{pH}$ 's. 


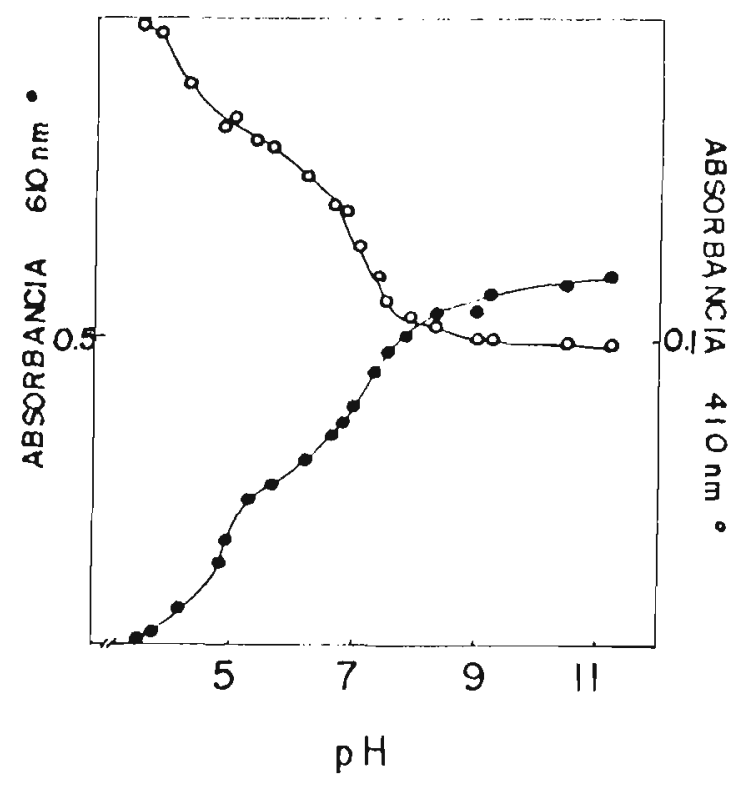

FIGURA 6 - Absorbâncias a 610 e a $410 \mathrm{~nm}$ (correspondentes aos comprimentos de onda onde a absorbância era máxima, na Fig. 5) da mesma mistura de corantes da Fig. 5 em função do pH.

igual a 4,5 (devido à dissociação dos grupos sulfônicos).

11. PREPARAÇÃO DE LIPOSSOMOS GRANDES DE DICETILFOSFATO DE $\mathrm{Na}^{+}(\mathrm{DCP})$.

1,0ml de uma solução 0,002M de DCP em clorofórmio mantida a temperaturas entre $30-40^{\circ} \mathrm{C}$ por um jato de ar quente (para solubilização do DCP no clorofórmio) foi injetạ da a uma velocidade aproximada de $0,2 \mathrm{ml} / \mathrm{min}$. em $4,0 \mathrm{ml}$ de uma solução aquosa ajustada a pH 8,2 com TRIS (trishidroximetilaminometano) $2 \mathrm{M}$ termostatizada a $70,0 \pm 0,5^{\circ} \mathrm{C}$ e borbulhada 
com argônio para se facilitar a vaporização do clorofórmio. Alíquotas ( $1 \mathrm{ml}$ ) da dispersão assim obtida foram filtradas a través de uma coluna de Sephadex G- 25 (1,8 x 14, cm) previamente saturada com essa mesma dispersão de DCP. Conteúdo de DCP em amostras ou em frações eluídas da coluna foi analisą do como fosfato inorgânico pelo método de Bottchen et al (1961). 
RESULTADOS

1. CARACTERIZAÇÃO FISICA.

Dispersões de DODAC, obtidas por vaporização de $\mathrm{CHCl}_{3}$, eluiram junto com o volume vazio ao serem filtradas em Sephadex G-25 (Fig. 7â). A absorbância (400nm) das frações que continham cloreto aumenta linearmente com (DODAC) $(0-1,5 \mathrm{mM})$ (Fig. 7b $)$. A absorptividade aparente (derivado do espalhamento) foi $300 \mathrm{M}^{-1} \mathrm{~cm}^{-1}$.

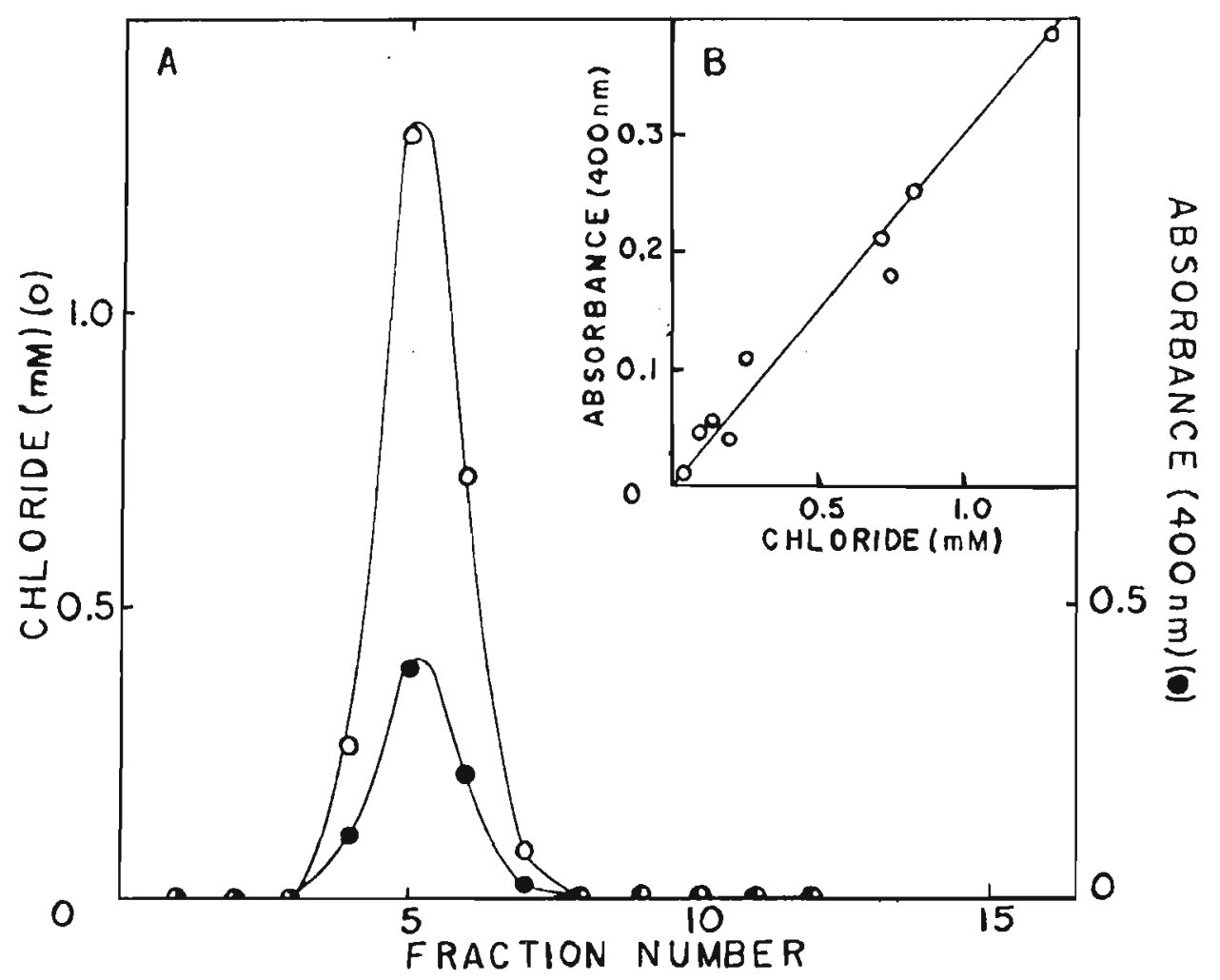

FIGURA 7 - Perfis de eluição de lipossomos grandes de DODAC $6 \mathrm{mM}$ em colluna de Sephadex G-25 (1,8 x $14,0 \mathrm{~cm})$; frações coletadas de $2,2 \mathrm{ml}$. (A) Absorbância a $400 \mathrm{~nm}$ de lipossomos grandes de DODAC em função da concentração de DODAC (B). 
As frações eluídas junto com o volume vazio da coluna de Sephadex G-25 (Fig. 7á) foram examinadas ao mi croscópio eletrônico tanto por coloração negativa quanto po sitiva revelando estruturas vesiculares fechadas com um diâa metro externo médio de $0,5 \mu$ (Fig. 8) e uma distribuição de diâmetros na faixa de 0,2 - 1,0 (Fig. 9).

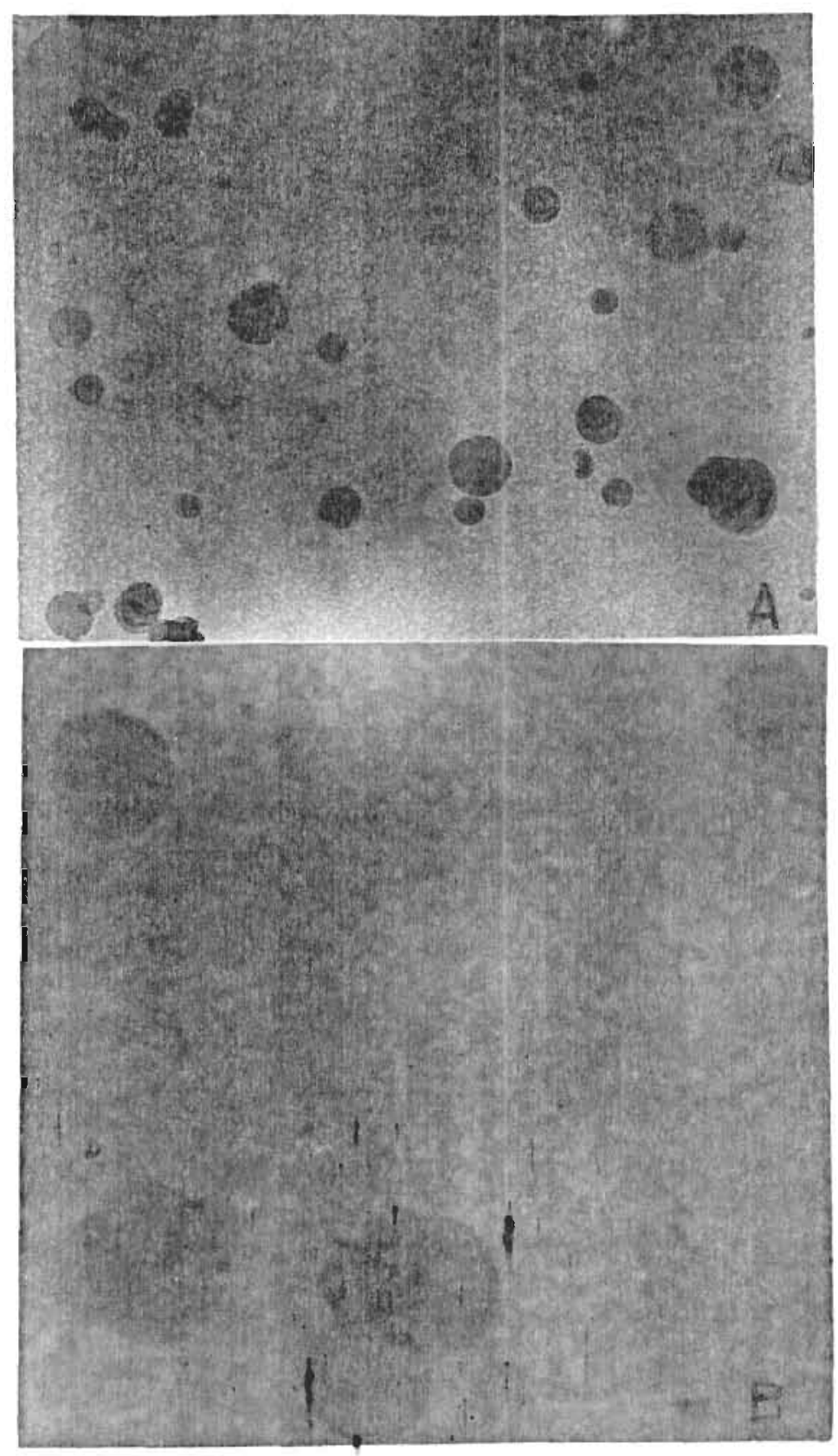

FIGURA 8 - Micrografias eletrônicas de lipossomos grandes de DODAC corados positivamente com molibdato de amônio 2\%. Aumentos de $7800 \mathrm{x}$ (A); $28500 \mathrm{X}$ (B). 


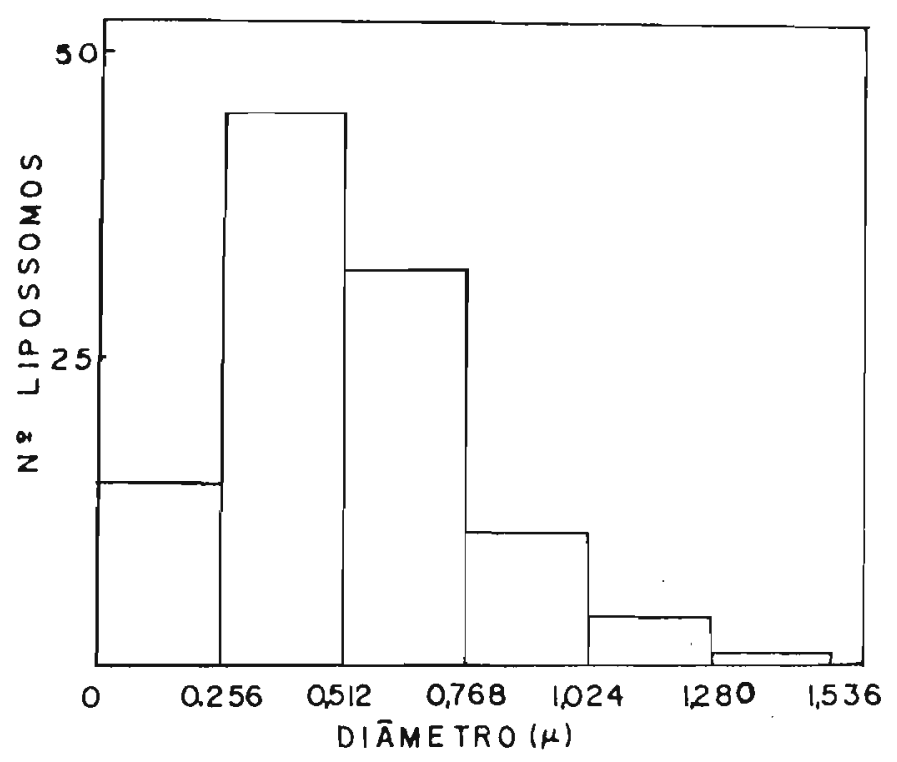

FIGURA 9 - Distribuição de uma população de lipossomos gran des de DODAC (108 lipossomos) segundo faixas dē diâmetro. Diâmetros foram medidos em micrografia eletrônica de lipossomos corados positivamente com molibdato de amônio $2 \%$ sob um aumento de $7800 \mathrm{x}$.

As temperaturas de transição de fase gel para a líquido-cristal foram determinadas para as vesiculas soni cadas de DODAC e para os lipossomos grandes de DODAC medindo-se absorbância em função da temperatura. Os pontos médios da transição de fase dos lipossomos grandes de DODAC corresponderam às temperaturas (TC) de $38,6^{\circ} \mathrm{C}$ para o aqueci mento e $34,8^{\circ} \mathrm{C}$ para o resfriamento. Para as vesículas soni cadas de DODAC, essas temperaturas foram, respectivamente, 37,5 e $34,4^{\circ} \mathrm{C}$. A faixa de temperaturas na qual houve a tran sição foi mais larga para as vesiculas sonicadas do que para os lipossomos grandes de DODAC (Fig. 10 e Tab. I). 


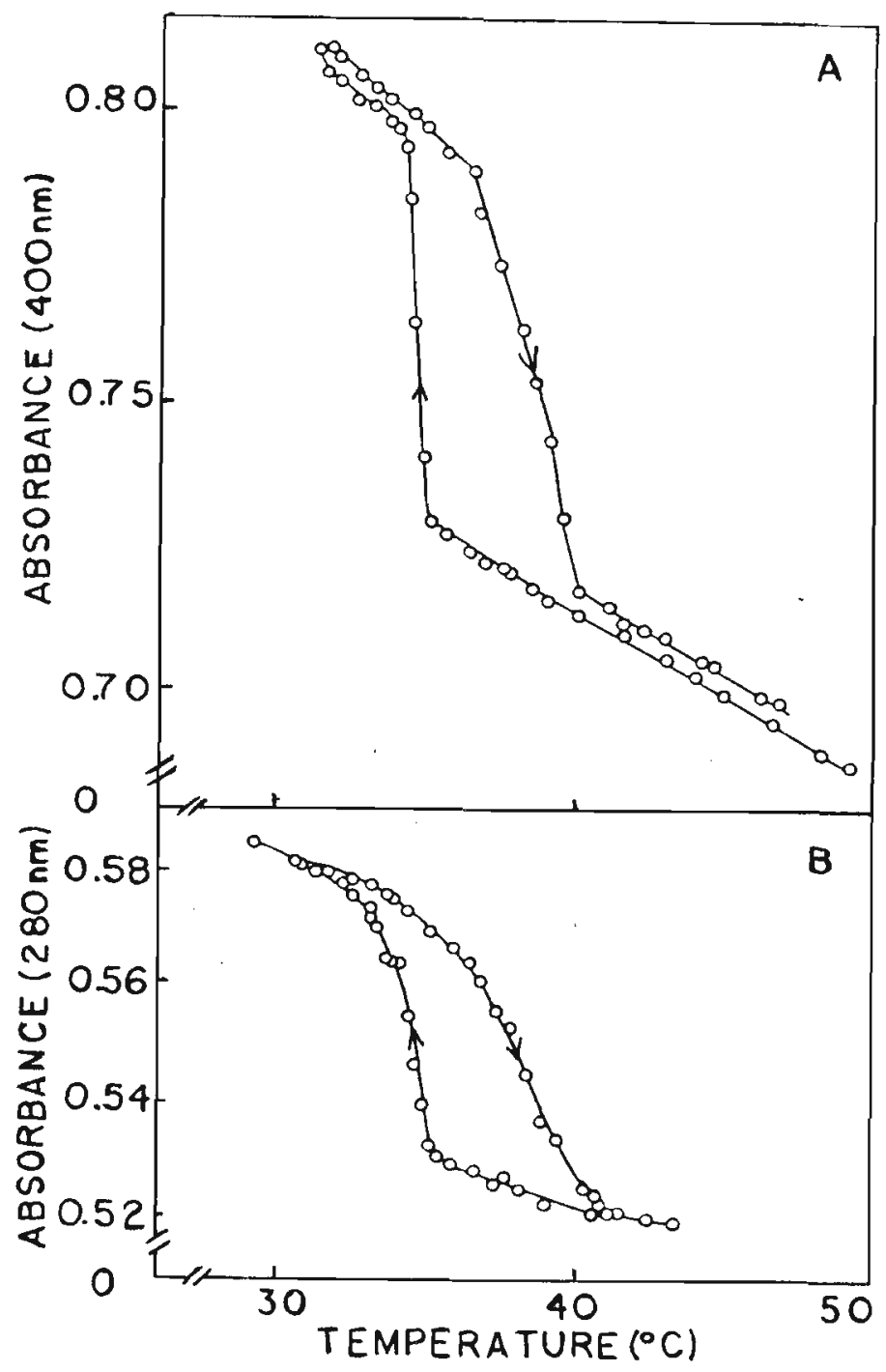

FIGURA 10 - Absorbância de dispersões de DODAC $(4,96 \mathrm{mM})$ em função da temperatura. Flechas indicam o sentido da variação de temperatura. $\operatorname{Em}(\mathrm{A}), \mathrm{Ii-}$ possomos grandes de DODAC. Em (B), vesículas sonicadas de DODAC.

2. CARACTERIZAÇÃo FUNCIONAL.

2.1. Impermeabilidade à sacarose, incorporação e adsorção de sacarose.

Volume do compartimento aquoso interno por mol 
INJETADAS

TABELA I - Temperaturas de transição de dispersões de DODAC obtidas por sonicação ou por injeção de solução clorofórmica de DODAC em água. 
de DODAC ( $\mathrm{V}$ em 1/mol) (vide "Material e Métodos) de vesículas sonicadas de DODAC foi determinado utilizando-se $\left({ }^{14} \mathrm{C}\right)$ sacarose como marcador hidrosolüvel do compartimento aquoso intravesicular. O valor médio obtido para o volume interno aparente $\underline{V}$ ( 4 experimentos) foi $0,33 \pm 0,201 / \mathrm{mol}$ (Fig.llA $)$. A retenção de $\left({ }^{14} \mathrm{C}\right)$-sacarose pelas vesículas sonicadas de DODAC foi-verificada pela obtenção de um único pico de radioatividade, coincidente com o pico de $\mathrm{Cl}^{-}$, em torno do volume vazio, ao longo de um período de atē 24 horas (Fig. $I I B, C)$

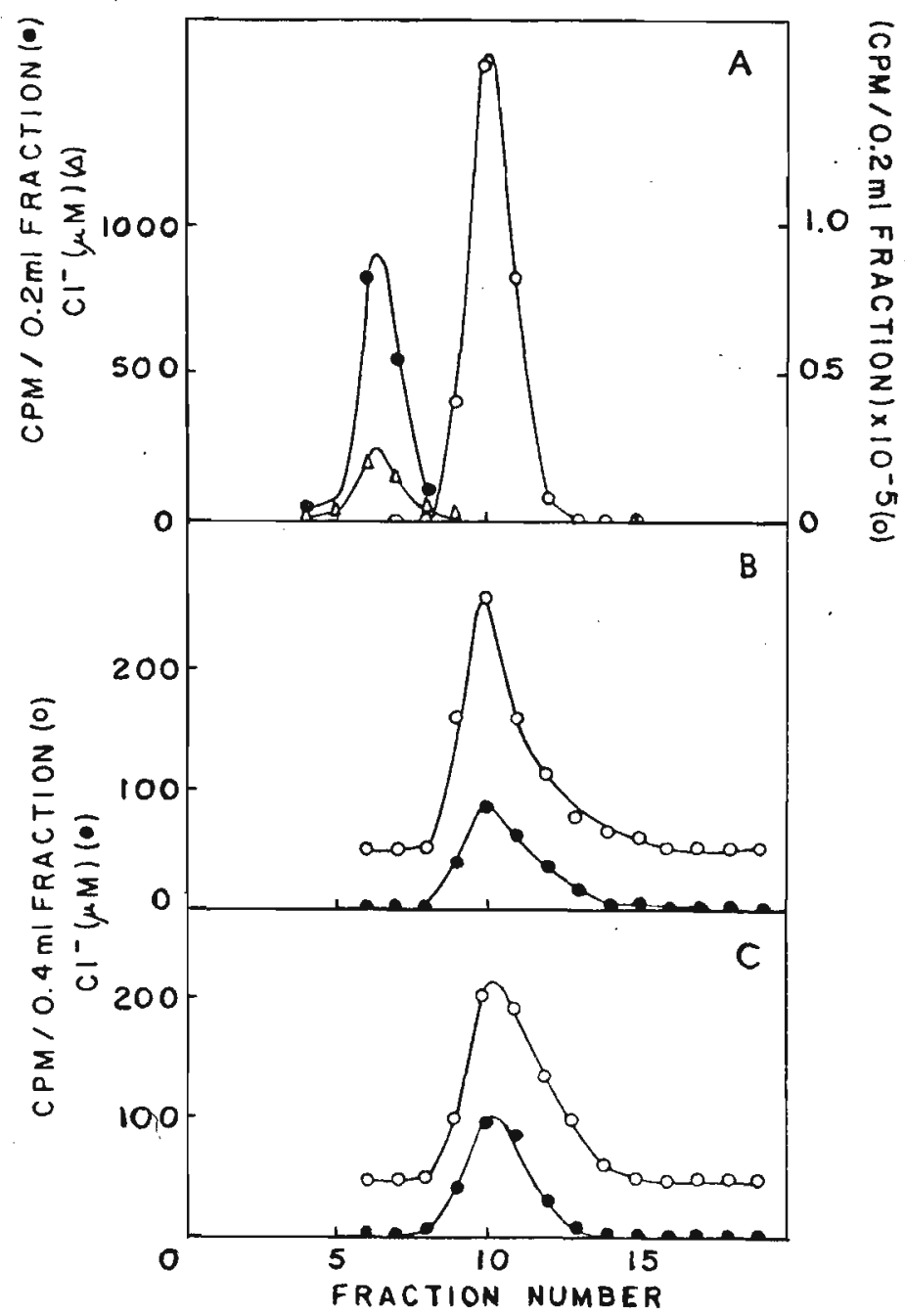

FIGURA 11 - perfil de eluição através de Sephadex G-25 (1,8 $\mathrm{X} 14,0 \mathrm{~cm})$ de $2 \mathrm{ml}$ de vesiiculas sonicadas de DODAC (10mM) preparadas em āgua contendo $(14 \mathrm{C})$-sacaro se. Frações coletadas de $2,2 \mathrm{ml}$ (A). Perfis de eluição através de Sephadex G-25 $(0,9 \times 21,0 \mathrm{~cm})$ de alíquotas de $0,2 \mathrm{ml}$ da fração 6 em (A), 2 horas (B) e 24 horas (C) após inĩcio da eluição de vesículas sonicadas de DODAC em (A). Fraçóes coletadas de $0,48 \mathrm{ml}$, em (B) e (C). 
Quando $\left({ }^{14} \mathrm{C}\right)$-sacarose foi adicionada a vesículas sonicadas de DODAC preparadas apenas em ãgua, o valor médio calculado para $\mathrm{V}$ foi $0,20 \pm 0,081 / \mathrm{mol}(\mathrm{n}=6)$ sendo que $\mathrm{V}$ manteve-se constante ao longo do tempo (Fig. $12 \mathrm{~A}, \mathrm{~B}, \mathrm{C}$ ). Já no instante zero, que correspondia a um controle de adsorção de $\left({ }^{14} \mathrm{C}\right)$ sacarose à bicamada, o valor de $V$ foi igual aos obtidos ulteriormente ( 2 e 24 horas).

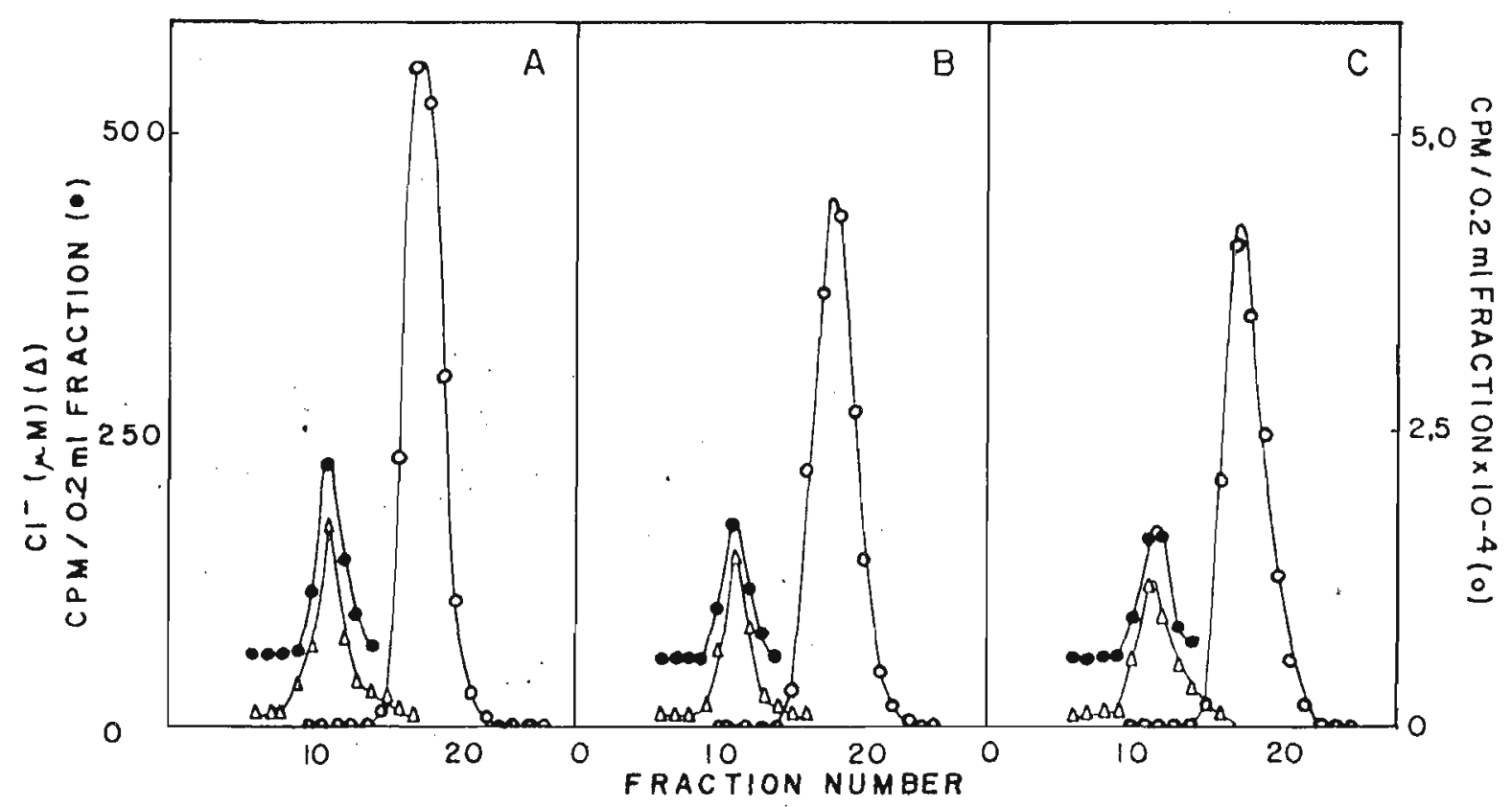

FIGURA 12 - Filtrações através de Sephadex G-25 (0,9 X 21,0cm) de $0,2 \mathrm{ml}$ de vesículas sonicadas de DODAC $(12,4 \mathrm{mil})$, preparadas em āgua, $0 \mathrm{~h}(\mathrm{~A}), 1 \mathrm{~h}(\mathrm{~B})$ e $24 \mathrm{~h}$ (C) após a adição de $\left({ }^{14} \mathrm{C}\right)$-sacarose. Frações coletadas de $0,48 \mathrm{ml}$.

Para lipossomos grandes de DODAC, V foi $9,66 \pm$ $1,301 / \mathrm{mol}(\mathrm{n}=3)$. Análogamente, aos resultados obtidos para as vesículas sonicadas de DODAC, não se detectou vazamento de $\left({ }^{14} \mathrm{C}\right)$-sacarose incorporada ou preenchimento dos $1 \underline{i}$ possomos com a mesma ao longo do tempo. Experimentos em câ 
mara de diálise de equilíbrio demonstraram que a velocidade de vazamento de $\left({ }^{14} \mathrm{C}\right)$-sacarose incorporada a lipossomos grandes de DODAC é desprezível em relação à velocidade com que é atingido o equilíbrio no sistema (Fig. 13A). A adição de $\left({ }^{14} \mathrm{C}\right)$-sacarose a lipossomos grandes de DODAC prepara dos em āgua, seguida de filtrações em gel em vārios instantes após a adição, resultou na obtenção de valores pratí camente constantes de $\mathrm{V}$ e iguais a $0,6 \pm 0,31 / \mathrm{mol} \quad(\mathrm{n}=4)$ (Fig. 13B) .

A Tabela II resume dados de $V$ para vesículas sonicadas e lipossomos grandes de DODAC calculados adicionando-se $\left({ }^{14} \mathrm{C}\right)$-sacarose antes ou depois da formação das dispersões. O. compartimento aquoso interno dos lipossomos gran des é cerca de 30 vezes maior que o das vesículas sonicadas. A adsorção, praticamente desprezível em relação à incorpora ção no caso dos lipossomos grandes, resulta da mesma ordem de grandeza que a incorporação nas vesículas sonicadas.

\subsection{Permeabilidades relativas ao $\mathrm{KCl}$.}

Bicamadas constituídas por fosfolípides naturais são pouco permeãveis a íons e altamente permeáveis à água (Bangham et al., 1976). Assim, com a finalidade de se comparar o comportamento dos lipossomos grandes de DODAC com o comportamento dos lipossomos de lecitina testou-se o efeito osmótico de alguns solutos iônicos e não-iônicos. o espalhamento de luz pelos lipossomos é dependente do diâmetro médio da dispersão (Van Holde, 1975). Esse diâmetro é 


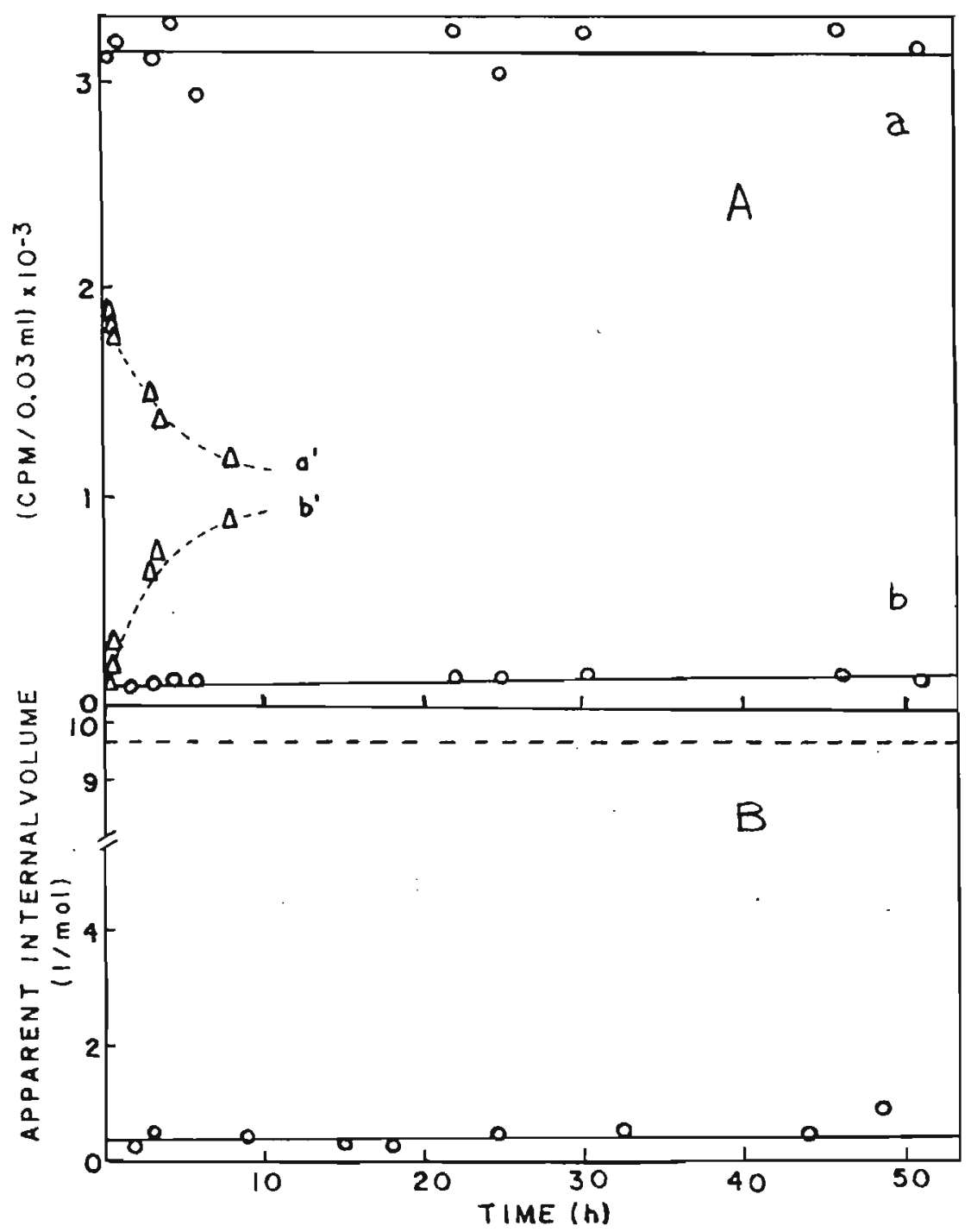

FIGURA 13 - Radioatividade em diferentes instantes nos dois lados de uma câmara de diálise de equilíbrio $(-)$ para lipossomos grandes de DODAC contendo $(14 \mathrm{C})-$ sacarose em um lado (a) e água no outro (b). Con

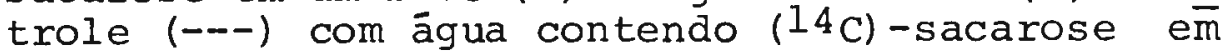
um lado ( $\mathrm{a}^{\prime}$ ) e àgua no outro (b') (A). Volumes internos aparentes ( $V$ ) em diferentes instantes calculados a partir de filtrações através de Sephadex $\mathrm{G}-25(1,8 \times 14,0 \mathrm{~cm})$ de lipossomos grandes de DODAC $9 \mathrm{mM}$ não-marcados, após adição de $(14 \mathrm{C})$ sacarose (-). Volume interno aparente médio para lipossomos grandes de DODAC preparados em ãgua contendo $\left(14_{C}\right)$-sacarose $(--)(B)$. 


\begin{tabular}{|c|c|c|c|c|c|c|c|}
\hline PREPARAÇÃO & $\begin{array}{c}v_{A} \\
(m I)\end{array}$ & $\begin{array}{c}\mathrm{C} \\
(\mathrm{mM})\end{array}$ & $\begin{array}{c}n \\
(\operatorname{mol} 1)\end{array}$ & 8. inc. & $\begin{array}{l}v_{i} \\
(1)\end{array}$ & $\begin{array}{c}v \\
(1 / \mathrm{mol})\end{array}$ & $\begin{array}{c}\bar{v} \\
(1 / \operatorname{mol})\end{array}$ \\
\hline Sonicação & 4 & 10 & 40 & 0.55 & 22 & 0.55 & $0.33 \pm .20$ \\
\hline em & 2 & 10 & 20 & 0.44 & 8.8 & 0.44 & $(n=4)$ \\
\hline \multirow{2}{*}{ (āguatsac.*) } & 2 & 11.9 & 23.9 & 0.148 & 3.0 & 0.23 & \\
\hline & 2 & 11.9 & 23.8 & 0.237 & 4.7 & 0.20 & \\
\hline Sonicação & $4(0)$ & 10 & 40 & 0.37 & 14.8 & 0.37 & $0.20 \pm .08$ \\
\hline em ägua e & $.2(0)$ & 12.4 & 2.5 & 0.195 & .39 & 0.16 & $(n=6)$ \\
\hline \multirow[t]{4}{*}{ adição sac*. } & $.2(1)$ & 12.4 & 2.5 & 0.234 & .468 & 0.19 & \\
\hline & $.2(34)$ & 12.4 & 2.5 & 0.201 & .402 & 0.16 & \\
\hline & $2(0)$ & 10 & 20 & 0.22 & 4.4 & 0.22 & \\
\hline & $2(6)$ & 10 & 20 & 0.19 & 2.8 & 0.19 & \\
\hline Injeção em, & 1 & 6.6 & 6.6 & 6.83 & 68.3 & 10.35 & $9.66 \pm 1.3$ \\
\hline \multirow[t]{2}{*}{$\left(a ́ g u a+s a c^{*}.\right)$} & 1 & 7.4 & 7.4 & 7.73 & 77.3 & 10.45 & $(n=3)$ \\
\hline & 1 & 6.0 & 6.0 & 4.91 & 491 & 8.18 & \\
\hline Injeção em & $I(0)$ & 5.0 & 5.0 & .033 & .33 & .07 & $0.64 \pm .30$ \\
\hline água e adı & $.5(2)$ & 5.0 & 2.5 & .17 & .85 & .343 & $(n=1)$ \\
\hline \multirow[t]{12}{*}{ ção sac*. } & $.5(15)$ & 5.0 & 2.5 & .26 & 1.30 & .524 & \\
\hline & $.5(18)$ & 5.0 & 2.5 & .22 & 1.10 & .444 & \\
\hline & $.5(44)$ & 5.0 & 2.5 & .34 & 1.70 & .685 & \\
\hline & $.5(169)$ & .5 .0 & 2.5 & .30 & 1.50 & .605 & \\
\hline & $I(0)$ & 9.4 & 9.4 & .50 & 5.00 & .532 & \\
\hline & $.5(2)$ & 9.4 & 4.7 & .81 & 4.05 & .862 & \\
\hline & $.5(3)$ & 9.4 & 4.7 & .47 & 2.35 & .500 & \\
\hline & $.5(9)$ & 9.4 & 4.7 & .51 & 2.55 & .543 & \\
\hline & $.5(24)$ & 9.4 & 4.7 & .63 & 3.15 & .670 & \\
\hline & $.5(33)$ & 9.4 & 4.7 & .72 & 3.60 & .766 & \\
\hline & $.5(48)$ & 9.4 & 4.7 & 1.10 & 5.50 & 1.170 & \\
\hline & $.5(74)$ & 9.4 & 4.7 & 1.12 & 5.60 & 1.191 & \\
\hline
\end{tabular}

OBS. : Entre parenteses,

encontram-se os intervalos de tempo (hrs) decorridosentre a adição de sacarose marcada e o início da cromatografia.

TABELA II - Volumes internos aparentes (V) calculados para vesiculas sonicadas e lipossomos grandes de DODAC.

$v_{A}$ : volume de amostra colocado no topo da coluna (ml);

$C$ : concentração de DODAC na amostra colocada no topo da co luna (mM):

$n$ : ne de moles de DODAC colocados no toro da coluna (iroles:

inc.: relaçāo entre total das cpm coletadas em torno do volume vazio e cpm coletadas em torno do volume internorxoor:

vi : volume incorporado pelas dispersões no volume de amostra colocado no topo da coluna $(\mathrm{il})$;

$\mathrm{V}: \frac{\mathrm{v}}{\mathrm{n}} \mathrm{i}$

$\vec{v}: \frac{\bar{v}_{1}+v_{2}+\cdots+v_{n}}{n}=$ valor médio do vol ume interno aparente. 
reduzido (ou aumentado) de acordo com o gradiente osmótico imposto através da membrana lipossomal. Portanto, o efeito osmótico dos solutos foi avaliado medindo-se a absorbância derivada do espalhamento em função do tempo após a imposição do gradiente osmōtico. Para soluções de solutos de índices de refração similares como a de $\mathrm{NaCl}$ e a de $\mathrm{KCl}$, foram obtidas curvas coincidentes de absorbância a $400 \mathrm{~nm}$ em função do tempo. Jā no caso dos gradientes osmóticos gerados com soluções de sacarose misturadas aos lipossomos, as curvas de absorbância em função do tempo ocorreram dentro de uma faixa de absorbâncias inferior às faixas das curvas correspondentes ao $\mathrm{KCl}$ e ao $\mathrm{NaCl}$, mas apresentaram forma e dimensões comparãveis às dessas ūltimas (Fig. 14). Como a absorbância varia diretamente com o espalhamento e como o espalhamento aumenta com a diferença de índice de refração entre a partícula e solução (Van Holde, 1975), o fato de se ter obtido uma faixa de absorbâncias por adição de soluções de sacarose menor que as faixas correspondentes às soluções de NaCl e de KCl significaria que a diferença de índice de refração entre as particulas (n) e a solução de sacarose $\left(n_{s}\right)$ seria menor que a diferença de índice entre as partícu las $(n)$ e a solução de $\mathrm{kCl}\left(\mathrm{n}_{\mathrm{k}}\right): \mathrm{n}^{-n_{\mathrm{s}}}<\mathrm{n}-\mathrm{n}_{\mathrm{k}^{\prime}}$ ou seja, $\mathrm{n}_{\mathrm{s}}>\mathrm{n}_{\mathrm{k}}$. De fato, é sabido que $\mathrm{n}_{\mathrm{s}}>\mathrm{n}_{\mathrm{k}}$, o que torna os re sultados obtidos (Fig. 14) perfeitamente compreensíveis e permite supor que o efeito osmótico induzido pela sacarose não difere do efeito osmótico induzido pelo $\mathrm{KCl}$ ou $\mathrm{NaCl}$. Por outro lado, soluções isoosmolares de $\mathrm{HCl}$ pro- 
moveram alterações de absorbância com o tempo nítidamente diferentes das anteriores (Fig. 14). HCl resultou menos efetivo que o $\mathrm{NaCl}, \mathrm{KCl}$ ou sacarose para induzir efeito osmó tico, uma vez que $1 / \Delta A$, um parâmetro que reflete $\circ$ volume lipossomal final apōs o encolhimento, resultou maior que

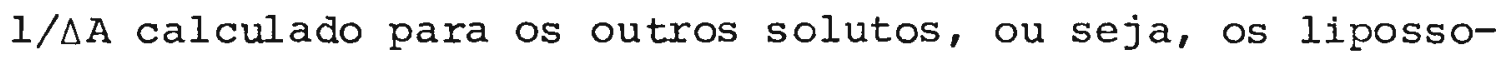
mos encolheram menos devido aos gradientes osmōticos de HCl do que devido aos gradientes osmöticos dos outros três solu u tos testados (Tabela III).

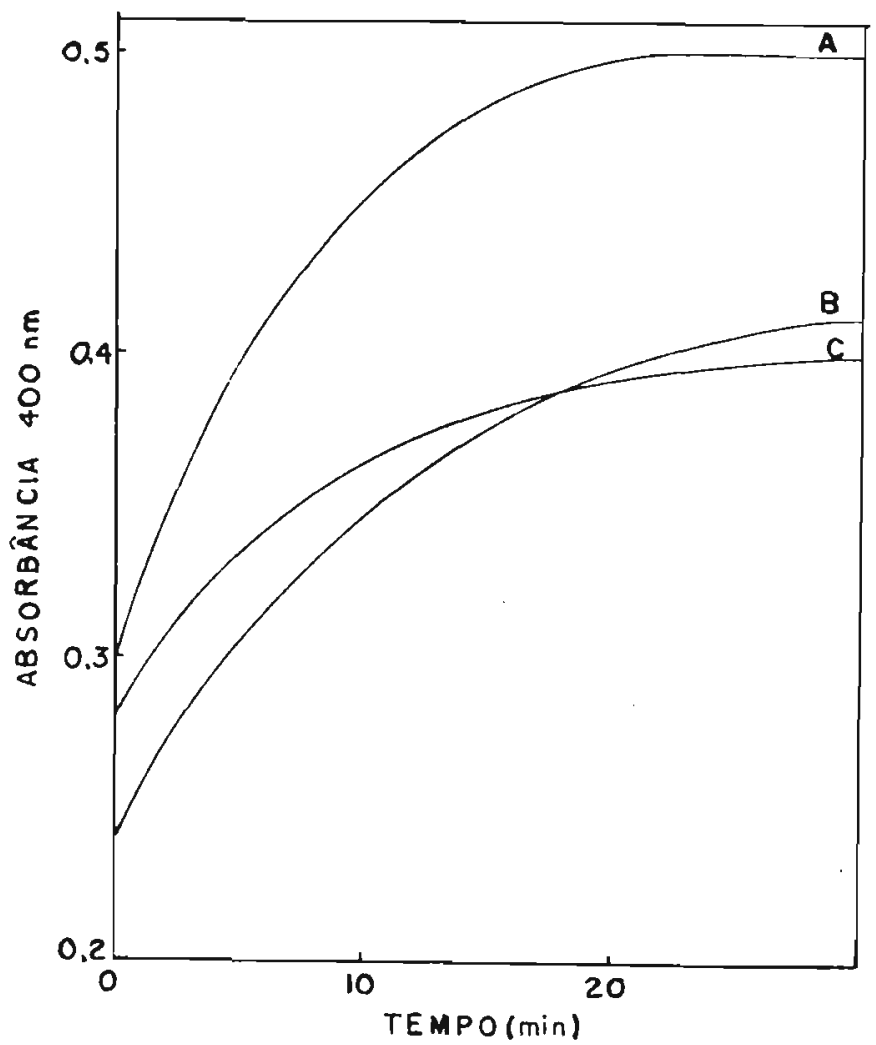

FIGURA 14 - Efeito comparado da adição de $0,5 \mathrm{ml}$ de soluções de $\mathrm{NaCl}(\mathrm{A}), \mathrm{KCl}(\mathrm{A}), \mathrm{HCl}$ (C) e sacarose (B) de mesma osmolaridade (200 miliosmóis) sobre a absorbância de lipossomos grandes de $\operatorname{DODAC}(3,0 \mathrm{mM}$; $0,5 \mathrm{ml})$ previamente preparados em água. 


\begin{tabular}{|c|c|c|c|c|c|c|c|c|c|}
\hline SALUTO & $\begin{array}{l}\mathrm{C} \\
(\mathrm{M})\end{array}$ & $\begin{array}{l}\Delta \mathrm{C} \\
(\mathrm{M})\end{array}$ & $\begin{array}{l}1 / \Delta \mathrm{C} \\
\left(\mathrm{M}^{-1}\right)\end{array}$ & $\mathrm{A}_{0}$ & $A_{f}$ & $1 / \Delta A$ & $\overline{1 / \Delta \mathrm{A}}$ & $\begin{array}{c}\circ v \\
\left(5^{-1}\right)\end{array}$ & $\begin{array}{c}\bar{v}^{\circ} \\
\left(5^{-1}\right)\end{array}$ \\
\hline \multirow[t]{4}{*}{ KCL } & 0.100 & 0.050 & 20.0 & .300 & .497 & 5.1 & $5.4+0.3$ & .150 & $.15+.02$ \\
\hline & & & & .305 & .486 & 5.5 & & .140 & \\
\hline & & & & .295 & .484 & 5.3 & & .170 & \\
\hline & & & & .300 & .473 & 5.8 & & .130 & \\
\hline \multirow[t]{4}{*}{$\mathrm{NaCl}$} & 0.103 & 0.051 & 19.5 & .295 & .480 & 5.4 & $5.6+0.1$ & .170 & $.15 \pm .06$ \\
\hline & & & & .295 & .473 & 5.6 & & .140 & \\
\hline & & & & .308 & .479 & 5.8 & & .120 & \\
\hline & & & & .298 & .478 & 5.6 & & .170 & \\
\hline \multirow[t]{5}{*}{$\mathrm{HCl}$} & 0.099 & 0.050 & 20.0 & .282 & .391 & 9.2 & $9.1 \pm 1.5$ & .064 & $.064 \pm .005$ \\
\hline & & & & .296 & .398 & 9.8 & & .057 & \\
\hline & & & & .296 & .398 & 9.8 & & .063 & \\
\hline & & & & .293 & .390 & 10.3 & & .065 & \\
\hline & & & & .280 & .435 & 6.5 & & .067 & \\
\hline \multirow[t]{3}{*}{$\begin{array}{l}\text { SACARO- } \\
\text { SE }\end{array}$} & 0.200 & 0.100 & 10.0 & .280 & .414 & 7.5 & $7.1 \pm 0.3$ & .110 & $.11 \pm .01$ \\
\hline & & & & .246 & .390 & 6.9 & & .100 & \\
\hline & & & & .256 & .399 & 7.0 & & .120 & \\
\hline
\end{tabular}

TABELA III - Parâmetros osmomētricos calculados para cinétị cas de encolhimento de lipossomos grandes de DODAC em soluções isoosmolares de vārios solutos. 
A Fig. 15 sumariza um experimento no qual lipossomos grandes de DODAC foram preparados em $\mathrm{KCl} \quad 19,5 \mathrm{mM}$ sendo então adicionados de soluções isotônicas de alguns so lutos ( $\mathrm{NaCl}, \mathrm{KCl}, \mathrm{HCl}$ e sacarose). Dessa forma, a penetra ção de soluto e o consequente inchamento lipossomal poderiam ser detectados como alterações de absorbância comotem po; a velocidade de penetração do soluto sendo proporcional à taxa de alteração de absorbância com o tempo. Como a absorbância a $400 \mathrm{~nm}$ resultou constante com o tempo para o $\mathrm{NaCl}_{\text {, }}$ - $\mathrm{KCl}$ e a sacarose deduz-se que $\mathrm{NaCl}$ e sacarose são tão impermeantes quanto $\circ \mathrm{KCl}$. Já $\circ \mathrm{KCl}$ induziu um ligeiro inchamento lipossomal, o que confirma que este soluto é ligeiramente mais permeante que o $\mathrm{KCl}$ (vide supra).

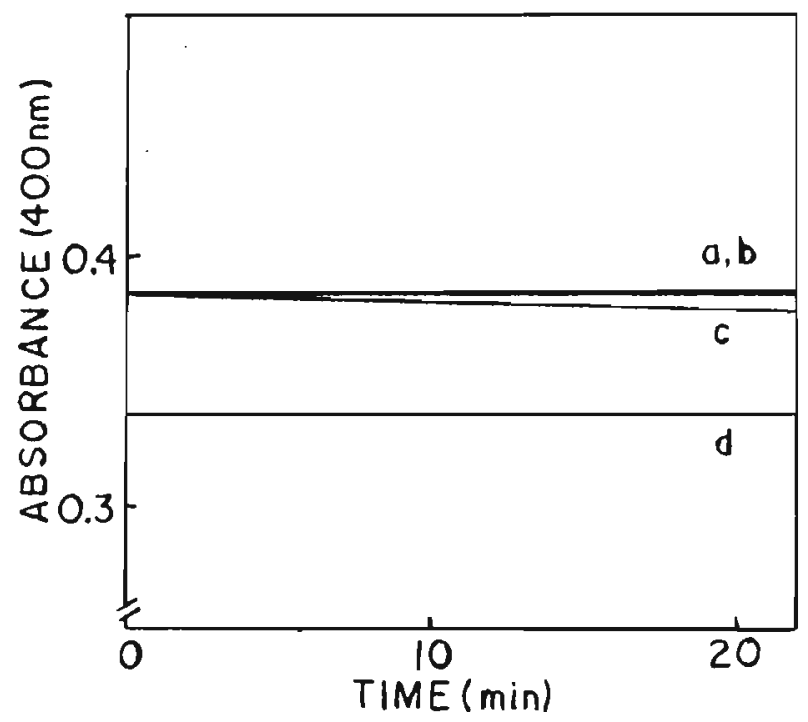

FIGURA 15 - Alterações de absorbância $(400 \mathrm{~nm})$ dependentes do tempo para $0,5 \mathrm{ml}$ de lipossomos grandes de DODAC $1,7 \mathrm{mM}$ preparados em $\mathrm{KCl} 19,5 \mathrm{mM}$ e adiciona dos de $0,5 \mathrm{ml}$ de $\mathrm{NaCl} 19,5 \mathrm{mM} \mathrm{(a);} 19,5 \mathrm{mM} \mathrm{KCl} \mathrm{(b);}$ $19,5 \mathrm{mM} \mathrm{HCl}$ (c); $39 \mathrm{mM}$ sacarose (d). 


\subsection{Propriedades osmóticas.}

A instabilidade de vesículas sonicadas de DODAC frente a sais é um fenômeno que pode ser observado a olho nū como formação de grumos após mistura de volumes iguais da dispersão sonicada em āgua e de solução de sal. Concentração final de sal da ordem de $20 \mathrm{mM}$ já é suficiente para induzir o fenômeno. Assim, sais como o $\mathrm{NaCl}$ e $\circ \mathrm{KCl}$ não seriam convenientes como solutos geradores de efeito os mótico em vesículas sonicadas de DODAC. Na Fig. 16, apresentammse alterações de absorbância com o tempo induzidas em lipossomos grandes de DODAC (Fig. 16A) ou em vesículas sonicadas de DODAC (Fig. 16B) por dois solutos diferentes: $\mathrm{KCl}$ e sacarose. O uso de KCl como soluto gerador de efeito

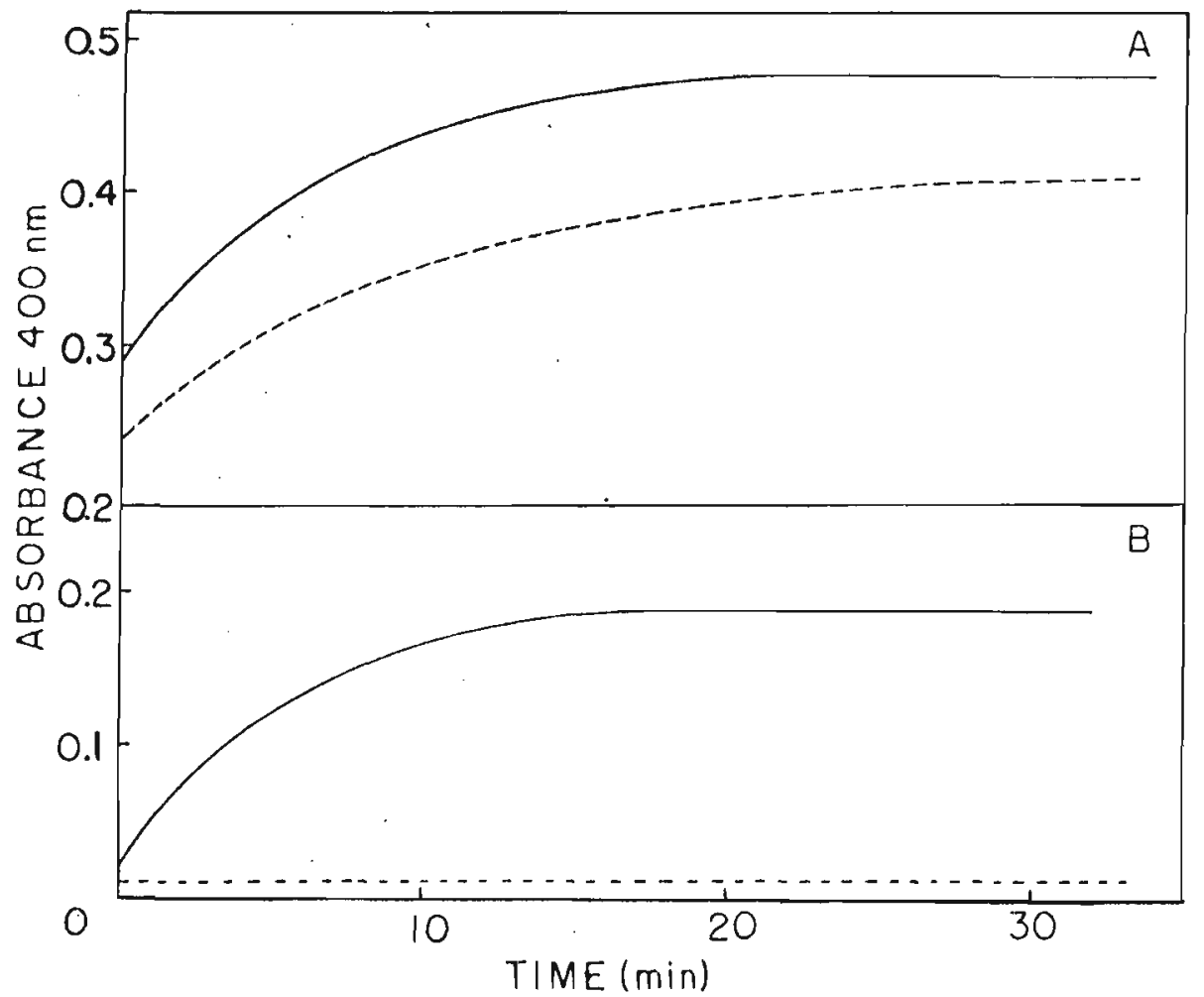

FIGURA 16 - Alterações de absorbância com o tempo após adição de $0,25 \mathrm{ml}$ de vesículas sonicadas $10 \mathrm{mM}$ de DODAC a 2,0 ml de $\mathrm{KCl} 0,1 \mathrm{M}(-)$ ou sacarose 0,17 $\mathrm{M}(--)(\mathrm{A}) ; 0,5 \mathrm{ml}$ de $\mathrm{KCl} 0,1 \mathrm{M}(-)$ ou sacarose $0,2 \mathrm{M}(---)$ a $0,5 \mathrm{ml}$ de lipossomos grandes de DODAC $3,0 \mathrm{mM}$ (B). 
osmótico pode conduzir a interpretações errôneas das altera ções de absorbância com o tempo, principalmente, no caso das vesículas sonicadas. Quando $\mathrm{KCl}$ é usado como soluto, obtém-se dependência linear de $v$ q com $\Delta \mathrm{C}_{\mathrm{KCl}}$ ou de $1 / \Delta \mathrm{A}$ com $1 / \Delta \mathrm{C}_{\mathrm{KCl}}$ apenas para os lipossomos grandes de DODAC (Fig. 17 $\mathrm{A}, \mathrm{B})$ e na faixa de $0-50 \mathrm{mM} \mathrm{KCl} \mathrm{(Fig.} \mathrm{17C,D).} \mathrm{Isso} \mathrm{mostra} \mathrm{que}$ no caso dos lipossomos grandes de DODAC, $\mathrm{KCl}$ pode ser utili zado crmo gerador de efeito osmôtico.

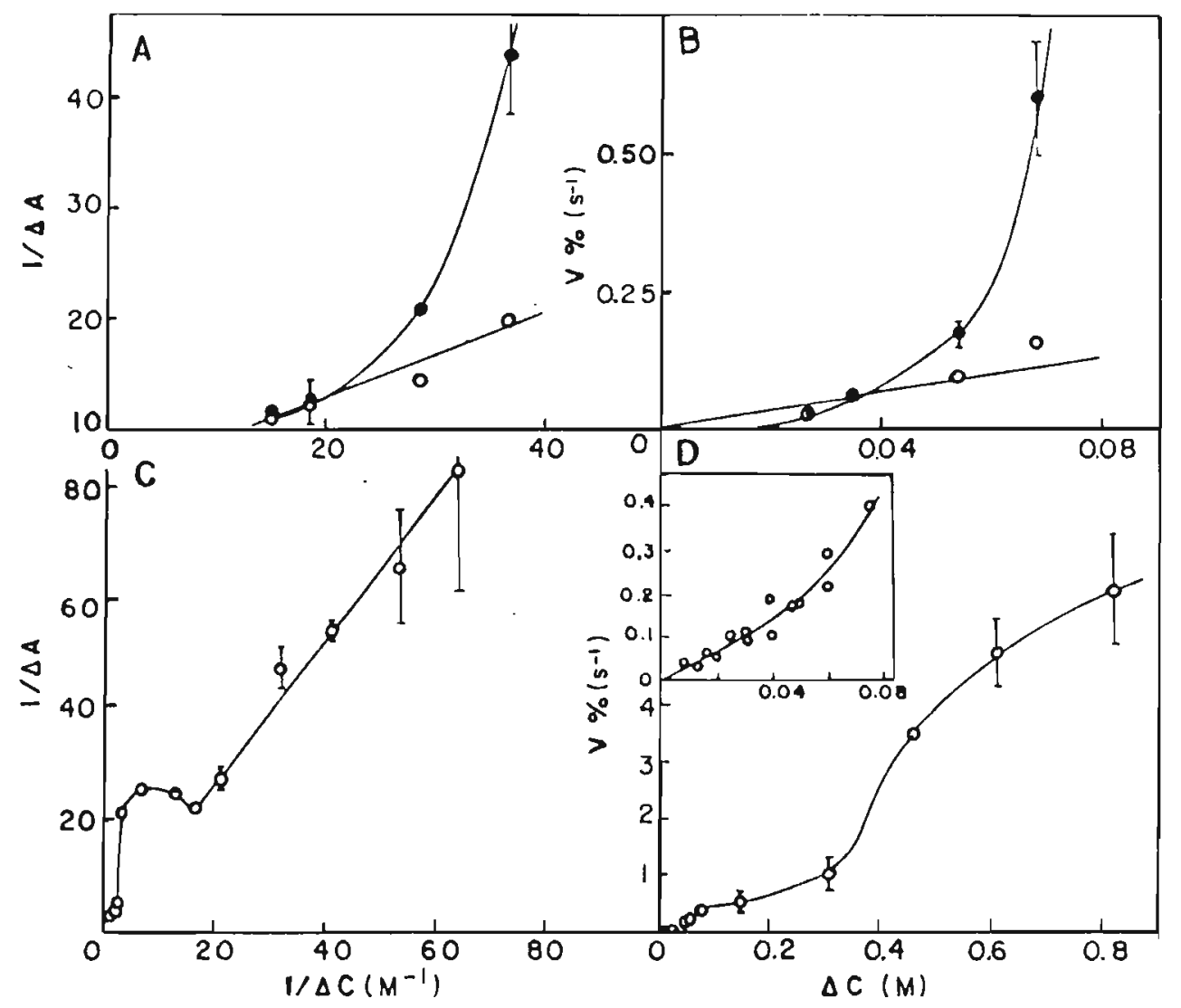

FIGURA 17 - Testes de comportamento de osmômetro em relação ao $\mathrm{KCl}$ para lipossomos grandes de DODAC (o) e vesiculas sonicadas de DODAC (•) a $400 \mathrm{~nm}$. 0,1ml de vesiculas sonicadas de DODAC $4,96 \mathrm{mM}$ ou lipos somos grandes de DODAC 4,96m preparados em água foram adicionados a $0,9 \mathrm{ml}$ de soluções de $\mathrm{KCl}:(\mathrm{A})$ e $(\mathrm{B}) ; 0,2 \mathrm{ml}$ de lipossomos grandes de DODAC $3 \mathrm{mM}$ preparados em água foram adicionacios a $0,8 \mathrm{ml}$ de soluções de $\mathrm{KCl}$ : (C) e (D). A inserção em (D) contém um gráfico amplificado de $\mathrm{V}$ o contra $\Delta \mathrm{C}$ para a menor faixa de concentra ções de KCl utilizada. 
A intensidade de radiação espalhada deve cres cer com o inverso da quarta potência do comprimento de onda $\lambda$ (Van Hold, p. 142, 1975). O espalhamento por sonicadas sonicadas de DODAC caí com $\lambda^{4}$ e, portanto, a absorbância de rivada do espalhamento deve $\operatorname{cair} \operatorname{com} \lambda^{4}$ (Fig. 18); mediçōes de absorbância de vesículas sonicadas de DODAC sendo mais sensíveis a $280 \mathrm{~nm}$ que a $400 \mathrm{~nm}$.

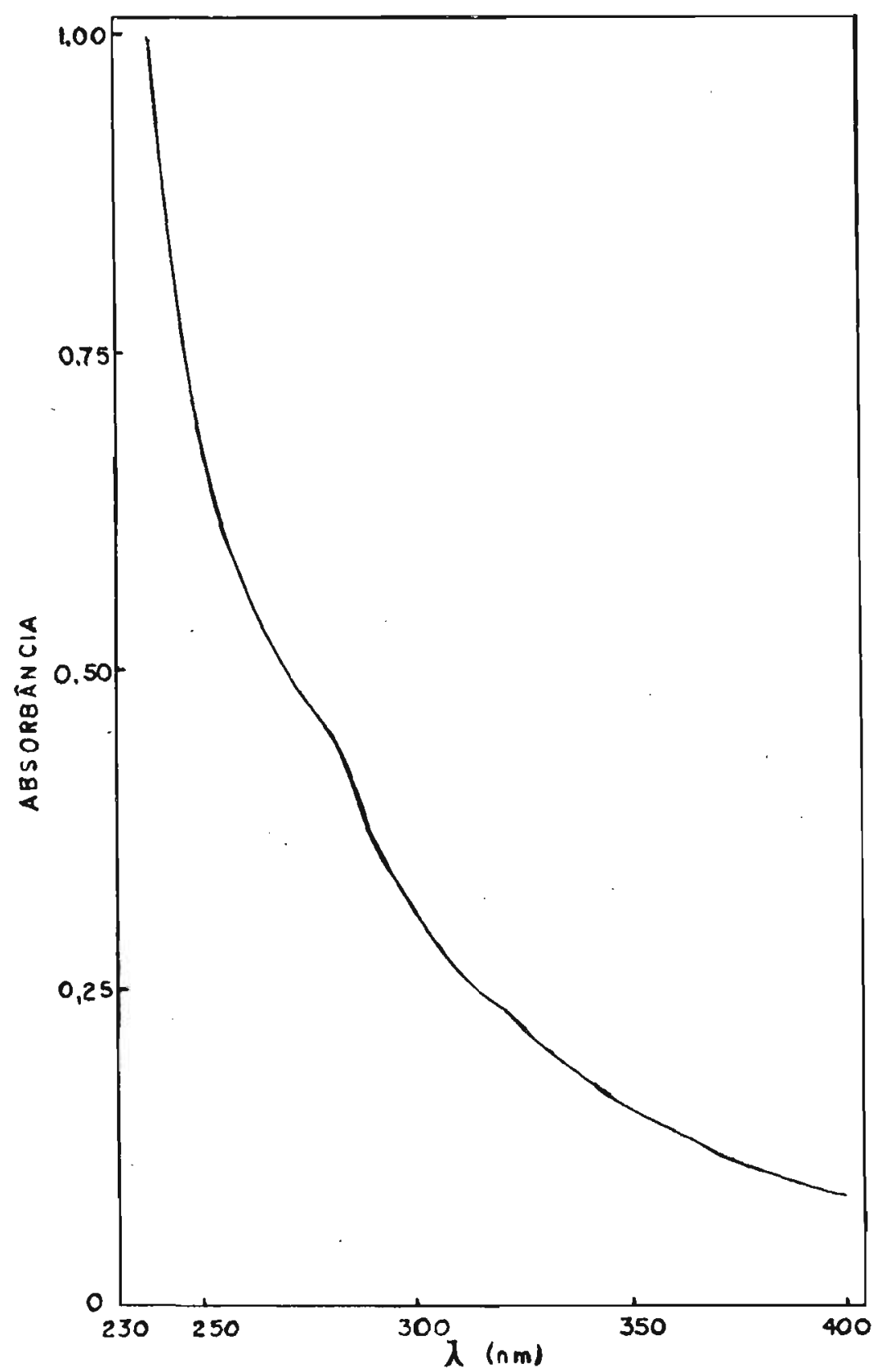

FIGURA 18 - Absorbância de vesículas sonicadas de DODAC 5mM em função do comprimento de onda. 
Para se confirmar o comportamento das vesículas sonicadas de DODAC a $400 \mathrm{~nm}$ (Fig. 18), alterações de absorbância com o tempo induzidas por $\mathrm{KCl}$ foram obtidas a 280 nm (Fig. 19) . o resultado foi análogo ao observado a $400 \mathrm{~nm}$.

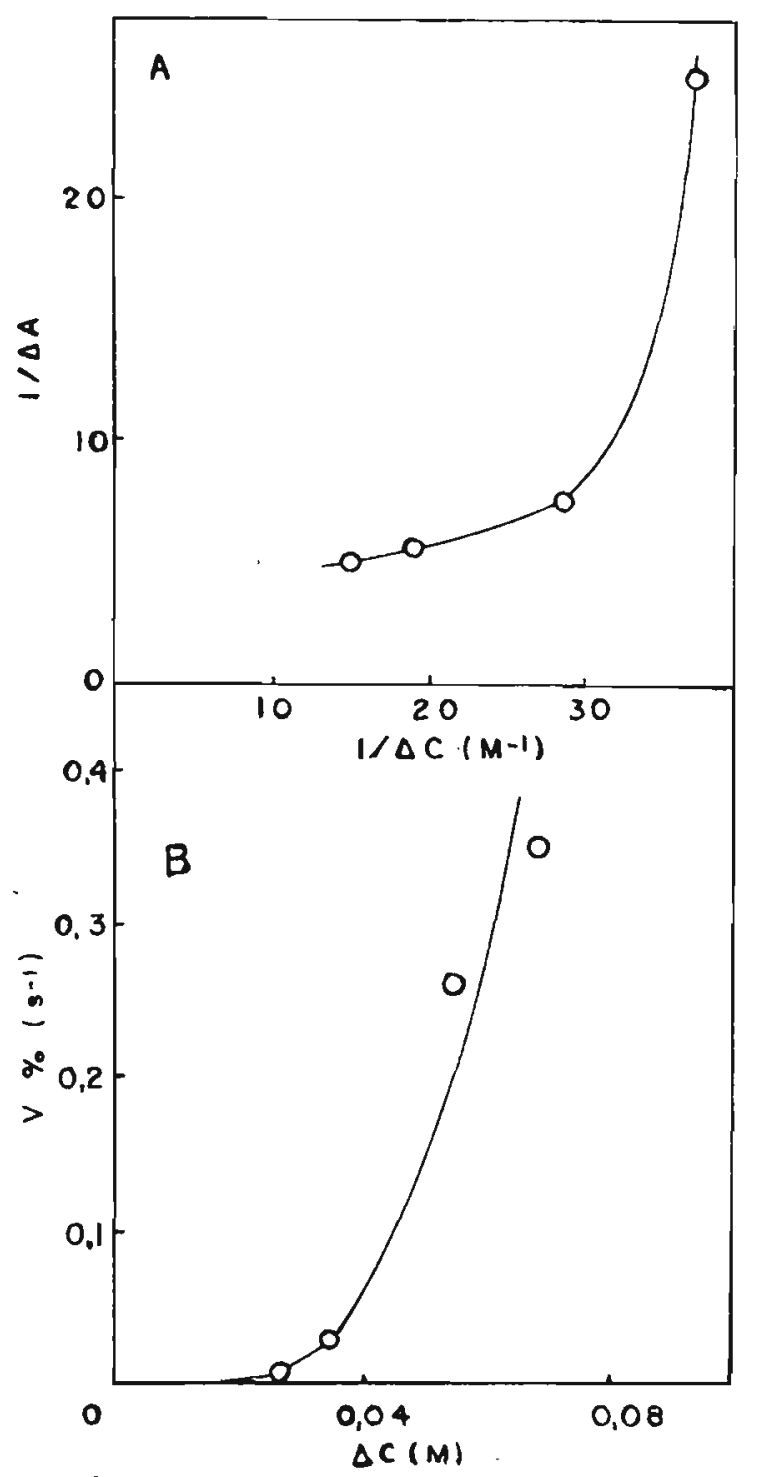

FIGURA 19 - Testes de comportamento de osmômetro em relação ao $\mathrm{KCl}$ para vesículas sonicadas de DODAC $4,96 \mathrm{mM}$ a $280 \mathrm{~nm}$. $0,1 \mathrm{ml}$ de vesículas sonicadas de DODAC foram adicionadas a $0,9 \mathrm{ml}$ de solução de $\mathrm{KCl}$.

Usando-se sacarose como soluto impermeante, não se detectou alteração de absorbância com o tempo em vesículas sonicadas de DODAC (vide Fig. 16B). Lipossomos grandes de DODAC, submetidos a gradientes osmöticos de sacarose, compor taram-se de forma a se obter linearidade para $v$ o versus gradientes de 
concentração de sacarose e para $1 / \Delta A$ contra o recíproco do gradiente de concentração de sacarose, dentro da faixa de concentrações de sacarose utilizada (Fig. 20A e B).

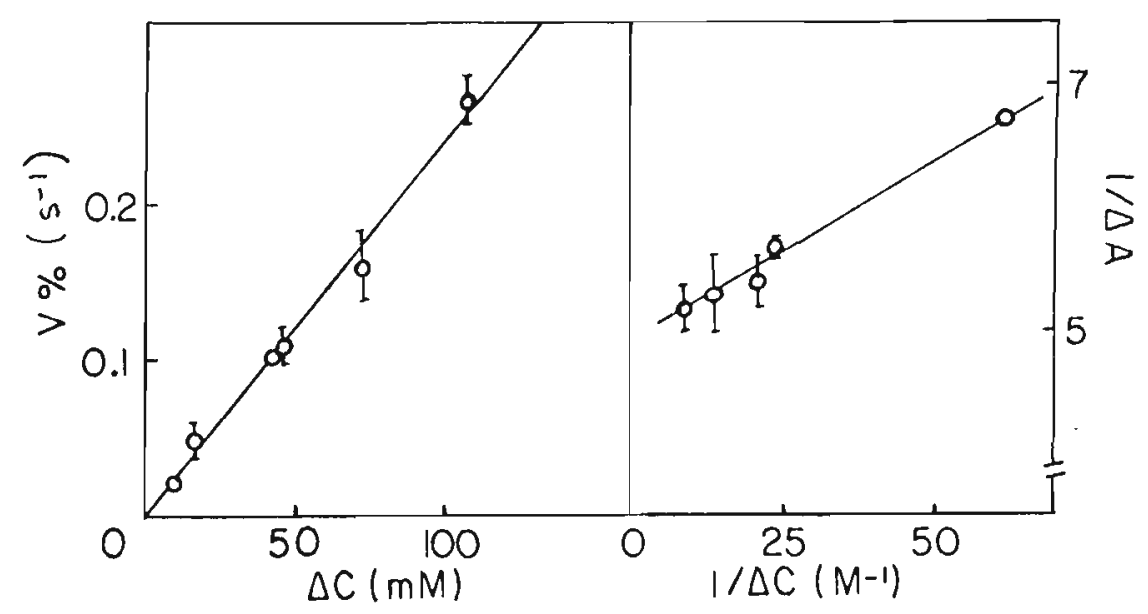

FIGURA 20 - Testes de comportamento de osmômetro de liposso mos grandes de DODAC em relação à sacarose à $400 \mathrm{~nm}$. $0,1 \mathrm{ml}$ de 1 ipossomos grandes de DODAC 2,1 $\mathrm{mM}$ foram adicionados a $0,9 \mathrm{ml}$ de solução de sacá rose.

Usando $\mathrm{HCl}$ como soluto gerador de efeito osmó tico, conforme o esperado para um soluto permeante, não se obteve linearidade das curvas (Fig. 2 IA e B). Assim, tanto solutos que induzem processos de agregação como o KCl quanto solutos que são permeantes são inadequados do ponto de vista de se obter comportamento análogo ao de um osmômetro.

Na Fig. 22, verifica-se o efeito da temperatura sôbre parâmetros $\mathrm{v}$ q e $\mathrm{S}$ obtidos com lipossomos grandes de DODAC submetidos a um gradiente osmótico de $\mathrm{KCl}$ situado dentro da faixa em que ocorre comportamento de osmômetro (vide Fig. 17C e D). V o cresceu com a temperatura em toda 


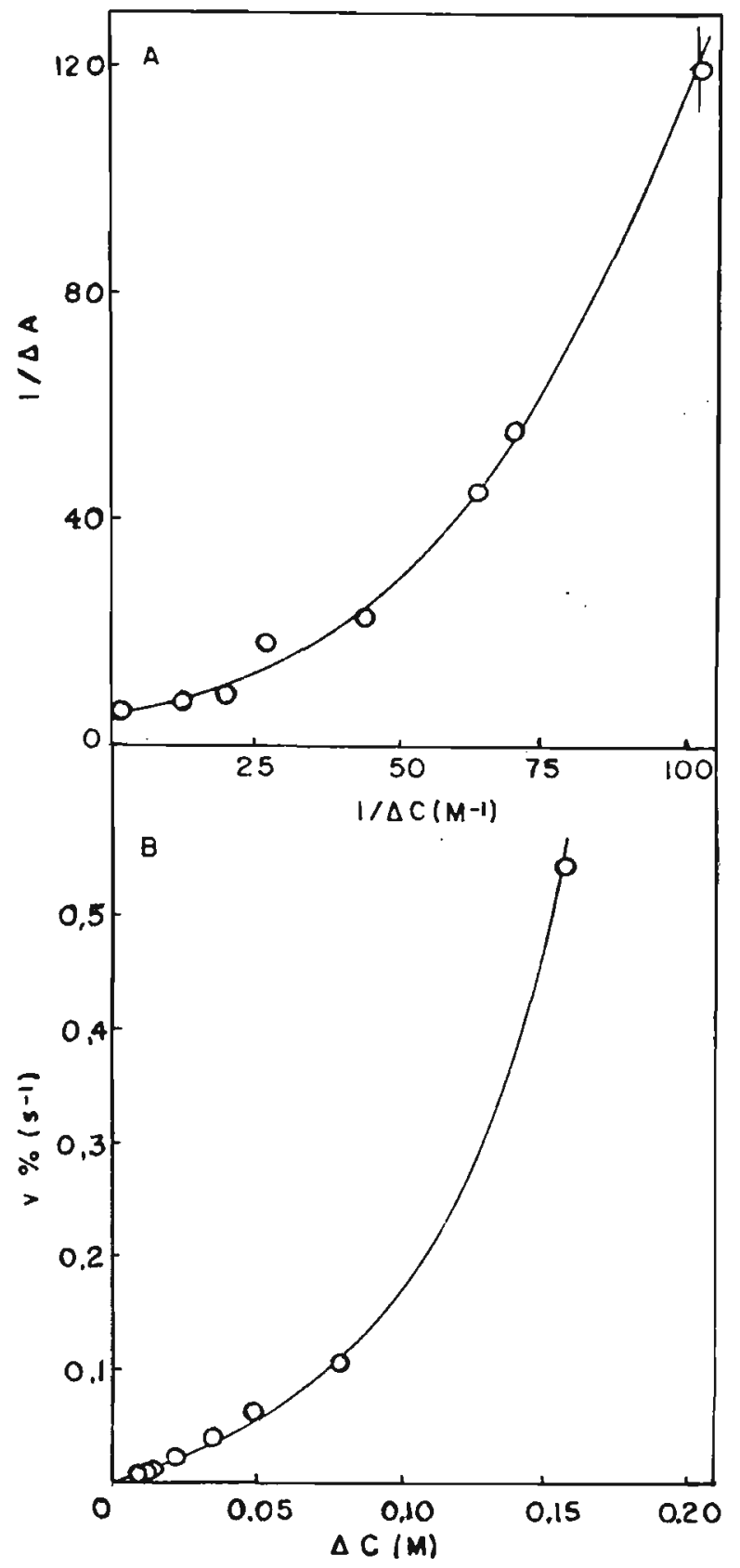

FIGURA 21 - Testes de comportamento de osmômetro de liposso mos grandes de DODAC em relação ao $\mathrm{HCl}$ a $400 \mathrm{~nm}$. $0,5 \mathrm{ml}$ de solução de $\mathrm{HCl}$ foi adicionado a 0,5 $\mathrm{ml}$ de lipossomos grandes de DODAC 3,0mM. 
faixa de temperaturas utilizada apresentando um aumento abrupto para temperaturas mais próximas da $\mathrm{T}_{\mathrm{C}} \cdot \mathrm{S}$ manteve-se praticamente constante para as temperaturas mais baixas, pạ ra, a seguir, decrescer, atingir um minnimo na $T_{C} e$ crescer imediatamente após a $\mathrm{T}_{\mathrm{C}}$ (Fig. $22 \mathrm{~A}$ e B).

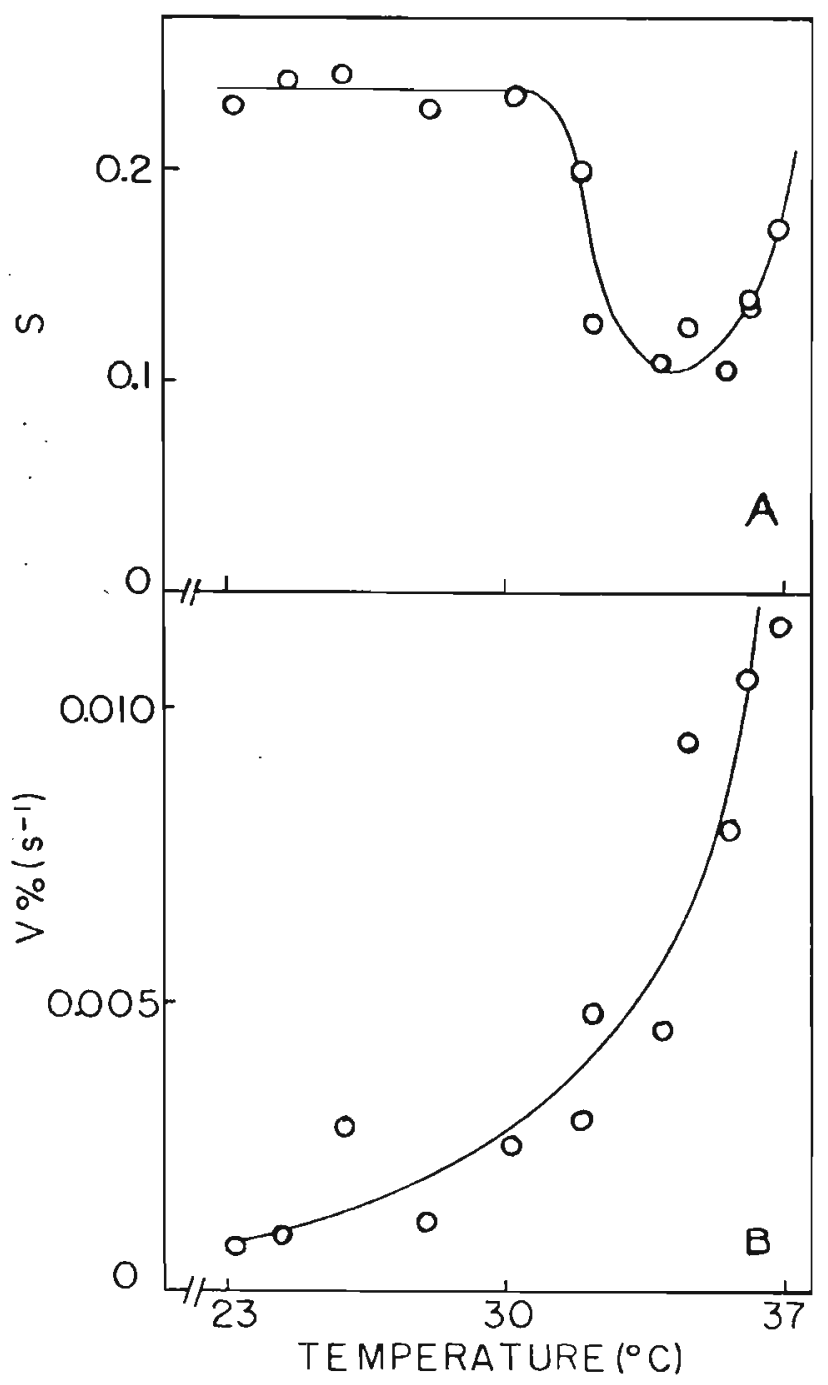

FIGURA 22 - Efeito da temperatura sôbre a extensão total de encolhimento (A) e sôbre a velocidade inicial de encolhimento (B) - 0,2ml de lipossomos grandes de DODAC 4,96mM foram adicionados a $0,8 \mathrm{ml}$ de $\mathrm{KCl}$ $30,4 \mathrm{mM}$. 
A reversibilidade do encolhimento lipossomal induzido pelo $\mathrm{KCl}$ foi testada obtendo-se reversão desse encolhimento em todos os casos (Fig. 23 e 24; Tabela IV). Na Fig. 23, lipossomos grandes de DODAC foram preparados em KCl $10 \mathrm{mM}$ e encolhidos em gradientes osmóticos de 9 e $18 \mathrm{mM}$ de $\mathrm{KCl}\left(\Delta \mathrm{C}_{\mathrm{KCl}}=9\right.$ e $\left.18 \mathrm{mM}\right)$; a reversão do gradiente sendo fei ta por diluição em água de alíquotas dos lipossomos encolhi dos. Como a isotonicidade do meio extralipossomal em relação ao interior lipossomal foi restabelecida, o valor final da absorbância após reversão do encolhimento $(0,330$ e 0,244) resultou idêntica, dentro do erro experimental, ao valor da absorbância inicial ao se induzir o encolhimento corrigida para a diluição $(0,318$ e 0,230) (Tabela IV) . Lipossomos gran des de DODAC foram preparados em água e encolhidos com gradi entes osmóticos de 40 e $50 \mathrm{mM}$ de $\mathrm{KCl}\left(\Delta \mathrm{C}_{\mathrm{KCl}}=40\right.$ e $\left.50 \mathrm{mM}\right)$; a reversão parcial do gradiente sendo feita por diluição em água de alíquotas desses lipossomos encolhidos e restando ain da gradientes de $\mathrm{KCl}$ de 16 e $8 \mathrm{mM}$ após essa diluição (Fig.24). Dessa forma, como o meio extralipossomal ainda estava hipertônico em relação ao interior dos lipossomos, não seria possí vel esperar uma reversão completa do encolhimento. Valores de absorbância ao final da reversão do encolhimento ( $A^{\prime} f$ ) fo. ram sensívelmente superiores aos valores de absorbância ao se iniciar o encolhimento $\left(A_{0}\right)$ corrigidos para a diluição ( A $_{0} /$ diluição) (Tabela IV). 


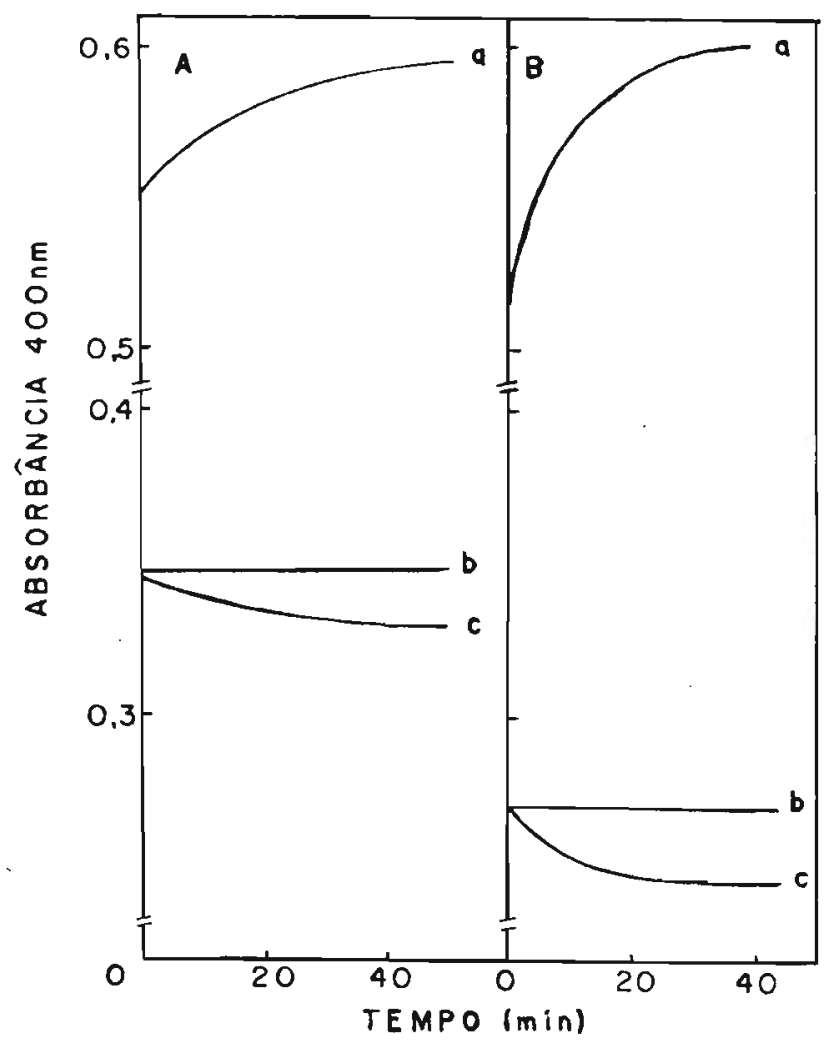

FIGURA 23 - Testes de reversibilidade de efeito osmótico em lipossomos grandes de DODAC preparados em $\mathrm{KCl}$ $10 \mathrm{mM}$. $\operatorname{Em}(\mathrm{A}),(\mathrm{a}) 0,3 \mathrm{ml}$ de lipossomos $1,5 \mathrm{mM}$ fo ram adicionados de $0,1 \mathrm{ml}$ de $\mathrm{KCl} 0,1 \mathrm{M} ;$ (b) $0,5 \mathrm{ml}$ de lipossomos encolhidos em (a) foram adicionados de $0,5 \mathrm{ml}$ de $\mathrm{KCl} 19 \mathrm{mM}$; (c) $0,5 \mathrm{ml}$ de lipossomos encolhidos em (a) foram adicionados de 0,5 $\mathrm{ml}$ de āgua. Em (B); (a) 0,8ml de lipossomos 1,5 $\mathrm{mM}$ foram adicionados de $0,2 \mathrm{ml}$ de $\mathrm{KCl} 0,1 \mathrm{M} ;$ (b) $0,5 \mathrm{ml}$ dos lipossomos encolhidos em (a) foram adicionados de $1,0 \mathrm{ml}$ de $\mathrm{KCl} 28 \mathrm{mM}$; (c) $0,5 \mathrm{ml}$ dos lipossomos encolhidos em (a) foram adicionados de $1,0 \mathrm{ml}$ de ägua. 


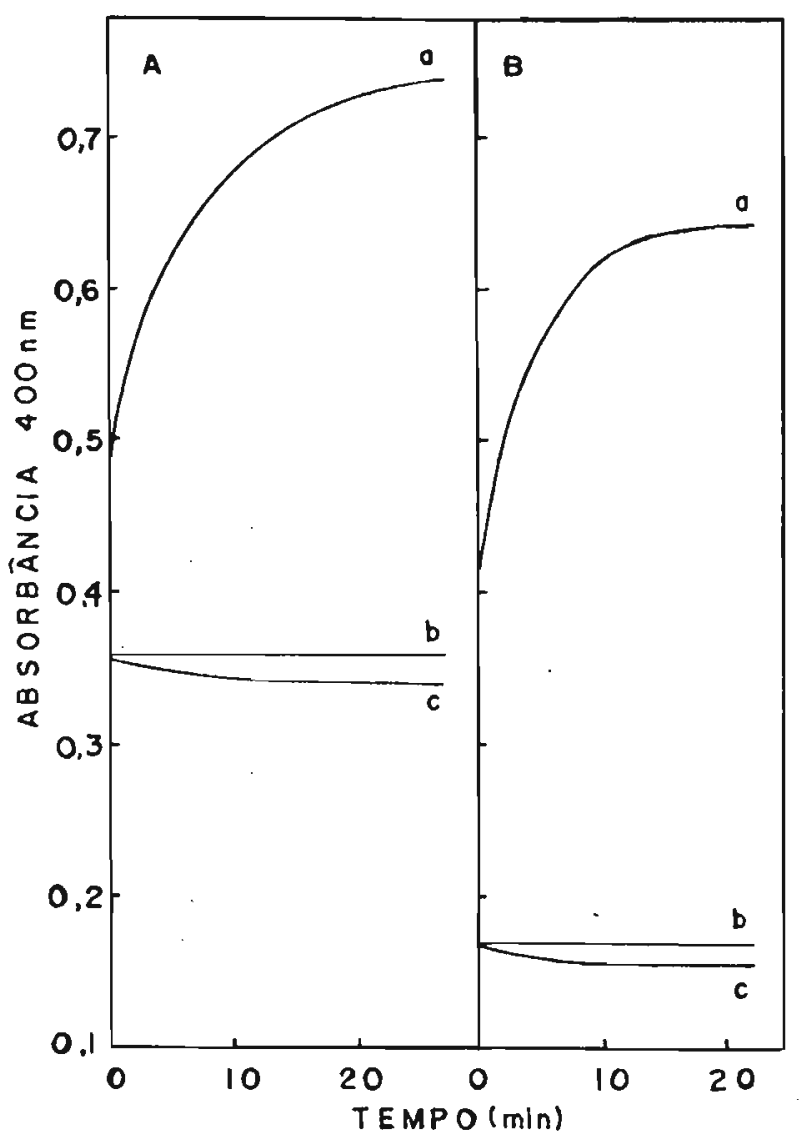

FIGURA 24 - Testes de reversibilidade de efeito osmōtico em lipossomos grandes de DODAC preparados em água. $\mathrm{Em}$ (A), (a) $0,6 \mathrm{ml}$ de lipossomos $2 \mathrm{mM}$ foram adicionados de $0,4 \mathrm{ml}$ de $\mathrm{KCl} 100 \mathrm{mM}$; (b) $0,4 \mathrm{ml}$ de $1 \mathrm{i}$ possomos encolhidos em (a) foram adicionados de $0,6 \mathrm{ml}$ de $\mathrm{KCl} 0,04 \mathrm{M}$; (c) $0,4 \mathrm{ml}$ de lipossomos encolhidos em (a) foram adicionados de $0,6 \mathrm{ml}$ de ăgua. Em (B), (a) $0,5 \mathrm{ml}$ de lipossomos $2 \mathrm{mM}$ adicionados de $0,5 \mathrm{ml} \mathrm{KCl} 10,0 \mathrm{mM}$; (b) $0,5 \mathrm{ml}$ liposso mos encolhidos em (a) adicionados de $2 \mathrm{ml} \mathrm{KCl} 5 \overline{0}$ $\mathrm{mM} ;$ (c) 0,4ml lipossomos encolhidos em (a) mais $2 \mathrm{ml}$ de àgua. 


\begin{tabular}{ccccccc}
\hline $\begin{array}{c}\Delta \mathrm{C}_{\mathrm{KCl}} \\
(\mathrm{mM})\end{array}$ & $\mathrm{A}_{\mathrm{O}}$ & $\mathrm{A}_{f}$ & $\mathrm{~A}^{\prime} \mathrm{A}_{\mathrm{f}}$ & $\begin{array}{c}\text { Diluição } \\
(\mathrm{X})\end{array}$ & $A_{\mathrm{O}}$ Diluição \\
\hline 9 & 0.550 & 0.598 & 0.346 & 0.330 & 1,73 & .318 \\
18 & 0.515 & 0.604 & 0.270 & 0.244 & 2,24 & .230 \\
40 & 0.490 & 0.745 & 0.360 & 0.340 & 2,07 & .237 \\
50 & 0.418 & 0.642 & 0.163 & 0.158 & 3,94 & .106 \\
\hline
\end{tabular}

TABELA IV - Avaliação da reversibilidade do fenômeno de encolhimento de lipossomos grandes de DODAC subme tidos aos gradientes osmóticos de $\mathrm{KCl}\left(\Delta \mathrm{C}_{\mathrm{KCl}}\right)$ indicados. 
Supondo que a reversibilidade do encolhimento é um critério adequado para se testar estabilidade dos 1ipossomos grandes de DODAC em soluções de $\mathrm{KCl}$, em concentrações de $\mathrm{kCl}$ em que os lipossomos fôssem instāveis, não ocorreria reversão. A Fig. 25 mostra testes de reversibilidade em lipossomos previamente encolhidos em soluções de $\mathrm{KCl}$ de concentrações crescentes. Em todos os casos, a diluição dos lipossomos encolhidos resultou em decréscimo da absorbância com o tempo, mesmo nos casos em que houve floculação a olho nú dos mesmos por adição de $\mathrm{KCl}$ ( $\mathrm{c}$ e d). Todavia, em $\underline{c}$ e $\underline{\text { d, }}$ - perfil das cinéticas é constituído por duas fases : uma inicial, rápida e outra posterior, bem mais lenta.

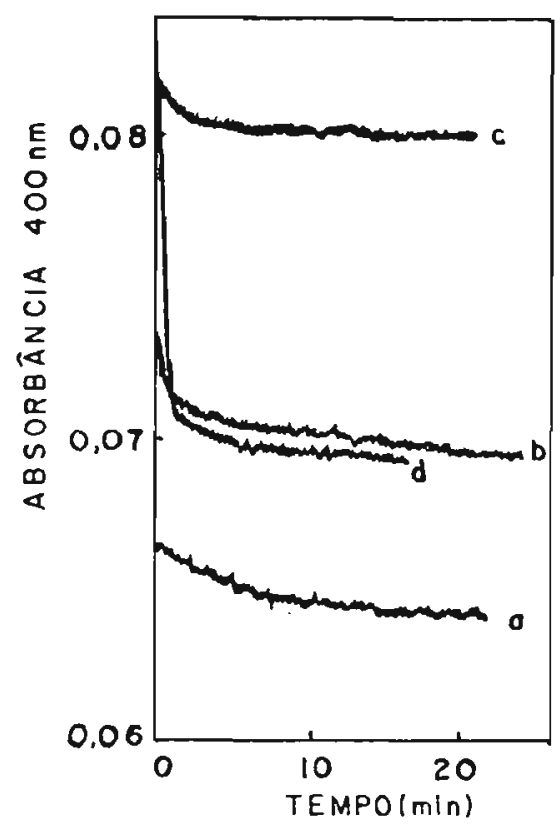

FIGURA 25 - Reversibilidade do aumento de absorbância com o tempo decorrente da adição de soluções de $\mathrm{KCl}$ a lipossomos grandes de DODAC preparados em água. Alíquota de ( $1 \mathrm{ml}$ lipossomos 1,4mM DODAC mais 1 $\mathrm{ml}$ sol ução $a, b, c$, ou $d$ de $\mathrm{KCl}$ ) foi adicionada de $2 \mathrm{ml}$ de água. a,b,c ou d referem-se à concentração da solução de KCl utilizada para promover o encolhimento; $a: 39 \mathrm{mM} ; b: 75,4 \mathrm{mM} ; \quad c$ : $97, \mathrm{mM} ; \mathrm{d}$ : $166 \mathrm{mM}$. 
2.4. Permeação de $\mathrm{H}^{+}$e/Ou $\mathrm{OH}^{-}$.

2.4.1. Mudança de fluorescência de 2 aminopiridina.

A Tabela V sumariza condições necessārias para se obter incorporação de 2 AP em vesículas sonicadas de DODAC ou em Iipossmos grandes de DODAC. Essas condições são : 1) saturação prévia da coluna com DODAC; 2) preparação das dispersões de DODAC a pH's inferiores ao pK da 2 AP (nesses $\mathrm{pH}^{\prime} \mathrm{s}, \mathrm{a} 2 \mathrm{AP}$ encontra-se protonada e, portanto, po sitivamente carregada).

2 AP foi incorporada a vesículas sonicadas de DODAC e a lipossomos grandes de DODAC, como mostra a Fig. 26A e B. V das dispersões calculado por essas $\%$ inc. de 2 AP e pela concentração de DODAC das dispersões re sultou igual a $0,061 / \mathrm{mol}$ para as vesículas sonicadas e 1,6 1/mol para os lipossomos grandes de DODAC. O volume inter no desses últimos foi, portanto, cerca de 30 vezes maior que aquele calculado para a dispersão sonicada. Assim, a relação dos volumes internos è confiāvel, já que mesmo utilizando uma sonda que é pouco incorporada (2 AP), a rela ção de volumes internos é idêntica àquela calculada com a sacarose (vide supra).

Para se controlar adsorção de 2 AP, lipos somos grandes de DODAC foram preparados em $\mathrm{HCl} 10^{-2} \mathrm{M}$ (2ml), adicionados de $2 \mathrm{AP}$ em $\mathrm{HCl} 10^{-2} \mathrm{M}(2 \mathrm{ml})$ e 10 minutos após essa adição foi feita uma separação entre 2 AP livre e incorporada (e/ou adsorvida) por filtração em Sephadex G-25 (Fig. 27). O volume interno calculado com esses dados foi 


\begin{tabular}{|c|c|c|c|}
\hline EXPERIMENTO & RECUPERAÇÃO & $\mathrm{Cl}^{-}$ & $\begin{array}{c}\text { INCORPORAÇÃO } \\
2 \mathrm{AP}\end{array}$ \\
\hline $\begin{array}{l}\text { Injeção ou sonicação de } \\
\text { DODAC em tampão borato } \\
\text { pH } 9,18 \text { com } 2 \text { AP } 10^{-3} \\
\text { Filtração em Sephadex } \\
\text { G-25 não-saturada com } \\
\text { DODAC }\end{array}$ & NÃO & & NÃO \\
\hline $\begin{array}{l}\text { Injeção ou sonicação de } \\
\text { DodAC em tampão borato } \\
\text { pH } 9,18 \text { com } 2 \text { AP } 10^{-3} \mathrm{M} \text {. } \\
\text { Filtração em Sephadex } \\
\text { G-25 saturada com DODAC }\end{array}$ & SIM * & & NÃO \\
\hline $\begin{array}{l}\text { Injeção ou sonicação de } \\
\text { DODAC em HCl } 10^{-2} \mathrm{M} \text { com } \\
2 \text { AP } 10^{-2} \mathrm{M} \text {. Filtração } \\
\text { em Sephadex G-25 satura } \\
\text { da com DODAC }\end{array}$ & $\operatorname{SIM} *$ & & SIM \\
\hline
\end{tabular}

* Recuperação de $\mathrm{Cl}^{-}$maior que $80 \%$.

TABELA V - Estabelecimento de condições para obtenção de vesículas sonieadas ou lipossomos grandes de DODAC com 2 AP incorporada. 


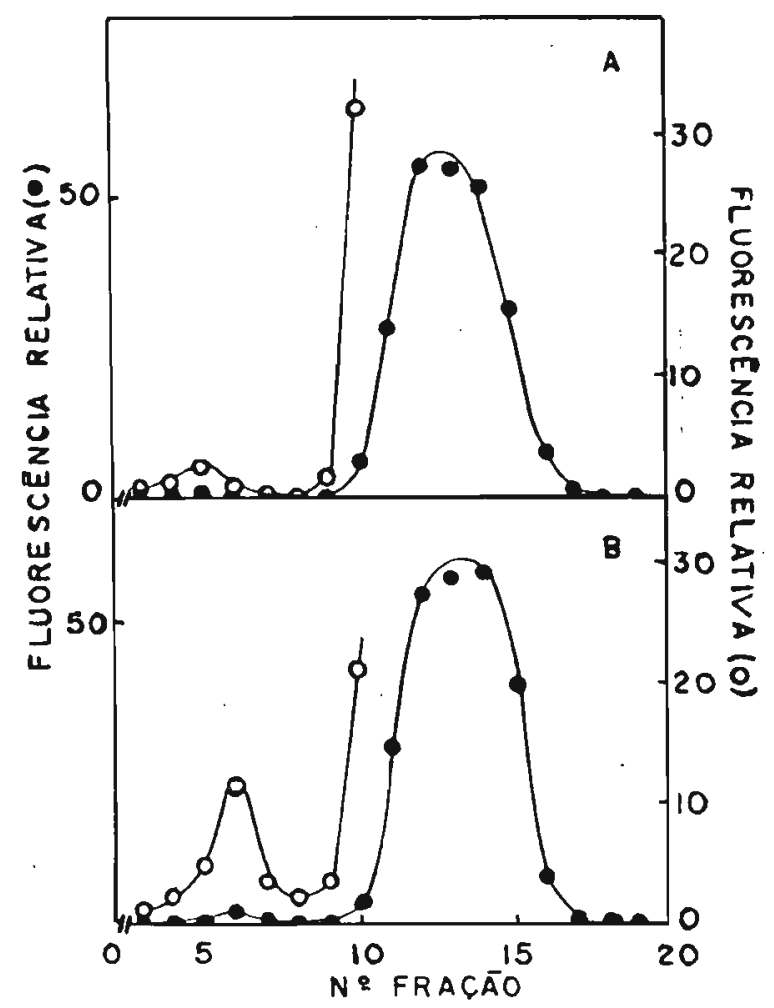

FIGURA 26 - Perfis de eluição de dispersões de DODAC preparados em $\mathrm{HCl} 10^{-2} \mathrm{M}$ e $2 \mathrm{AP} 10^{-2} \mathrm{M}$ através de $\mathrm{Se}-$
phadex $\mathrm{G}-25(1,8 \mathrm{X} 15,0 \mathrm{~cm})$ usando-se $\mathrm{HCl} 10^{-2} \mathrm{M}$ como eluente. Frações el uídas da coluna foram diluídas $10 \mathrm{X}$. (A) Eluição de $1 \mathrm{ml}$ de vesículas sonicadas de DODAC $10 \mathrm{mM}$. Leituras de fluores cência relativa nas sensibilidades de $10 / 0$ (o) e 1/0 (•). Volume interno aparente de $0,061 / \mathrm{mol}$. (B) Eluição de lipossomos grandes de DODAC $6 \mathrm{mM}$ nas sensibilidades de $30 / 8$ (o) e $0,9 / 8$ (०). Vo lume interno aparente de $1,61 / \mathrm{mol}$.

$0,012 \mathrm{l} / \mathrm{mol}$, um valor praticamente desprezível em relação ao anteriormente obtido (Fig. 26B) de $1,61 / \mathrm{mol}$.

4 horas após o início da filtração dos lipossomos grandes de DODAC na coluna de Sephadex (vide Fig.26B), adicionou-se $0,2 \mathrm{ml}$ de $\mathrm{NaOH}(0,5 \mathrm{~N})$ a $4 \mathrm{ml}$ de $(0,5 \mathrm{ml}$ tubo $6+$ $4,5 \mathrm{ml} \mathrm{HCl} 10^{-2} \mathrm{M}$ ) obtendo-se uma queda imediata de fluorescência de, aproximadamente $70 \%$ do valor inicial seguida de 


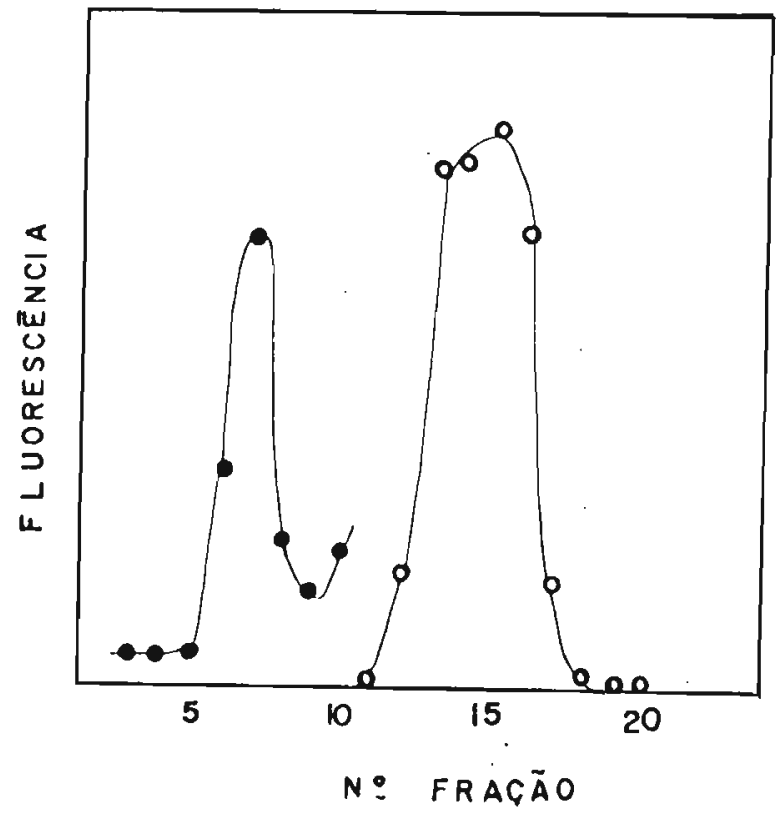

FIGURA 27 - Perfil de eluição de 2 AP através de Sephadex G-25 $(1,8 \times 15,0 \mathrm{~cm})$. $1 \mathrm{ml}$ de lipossomos grandes de DODAC $6 \mathrm{mM}$ preparados em $\mathrm{HCl} 10^{-2} \mathrm{M}$ foram adicionados de 2 AP $10^{-2} \mathrm{M}$ e cromatografados em $\mathrm{Se}-$ phadex G-25 para separação entre 2 AP adsorvida e/ou incorporada e 2 AP livre. Fluorescência lida nas sensibilidades de $100 / 0$ (e) e $1 / 0$ (o).

uma queda lenta de 15\%. Após atingido um nível estacionārio, a adição de $0,2 \mathrm{ml}$ de $\mathrm{HCl}$ IN levou ao valor da fluorescência atingido após a queda rápida e correspondente ao iní cio da queda lenta (Fig. 28A e B).

48 horas apōs início da filtração dos liposso mos grandes de DODAC na coluna, a repetição do teste de adi ção de $\mathrm{NaOH}$ resultou em uma queda imediata de fluorescência de $60 \%$ seguida de outra queda lenta de $1,24 \%$ do valor inicial antes de se alterar o $\mathrm{pH}$ externo (Fig. 29). 


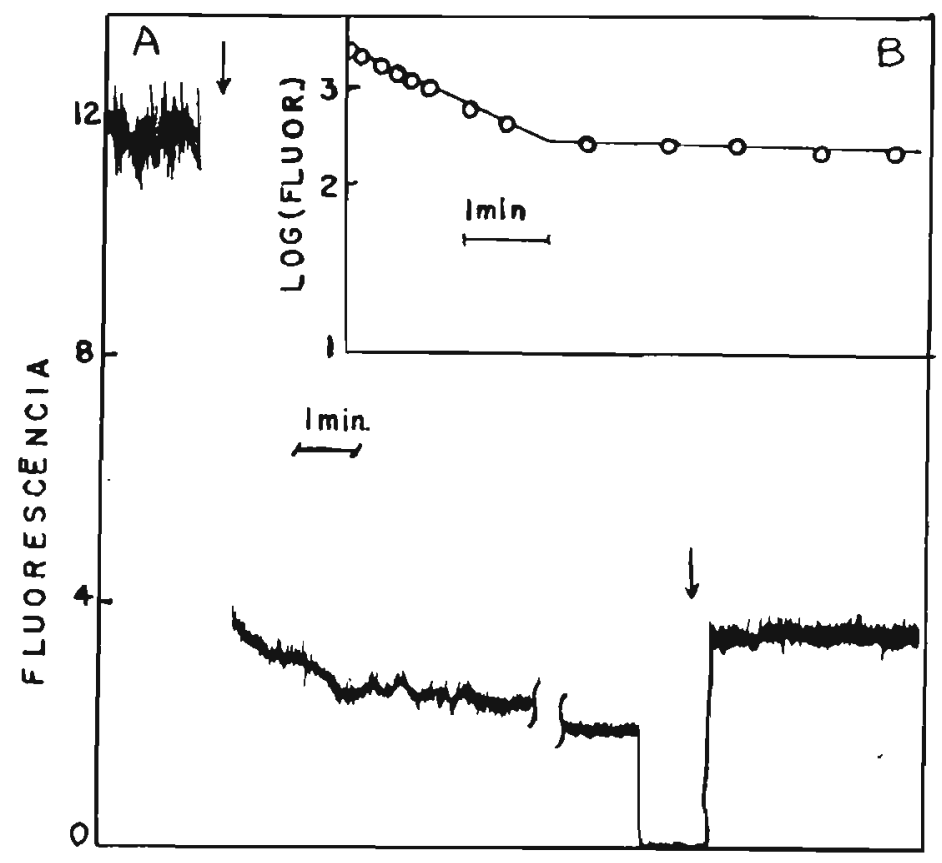

FIGURA 28 - Transiente de fluorescência de 2 AP incorporada a lipossomos grandes de DODAC após alteração de $\mathrm{pH}$ do meio extralipossomal. $\mathrm{Em}(\mathrm{A}), 0,2 \mathrm{ml} \mathrm{NaOH}$ $0,5 \mathrm{~N}$ foram adicionados a $4,0 \mathrm{ml}$ da fração 6 diluída $10 \mathrm{X}$ em $\mathrm{HCl} 10^{-2} \mathrm{M}$ e 4 horas após eluição dos lipossomos em Sephadex. Modo "energy". Sen sibilidade 30/9. A segunda seta indica a adi = ção de $0,2 \mathrm{ml}$ de $\mathrm{HCl} 1 \mathrm{~N}$. Em (B), o logarítmo da fluorescência foi plotado contra otempo para a cinética obtida em (A).

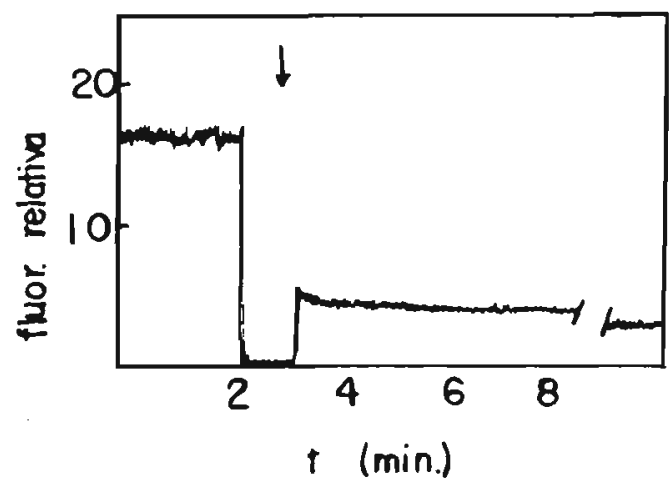

FIGURA 29 - Transiente de fluorescência de 2 AP incorporada a lipossomos grandes de DODAC após alteração de $\mathrm{pH}$ do meio extralipossomal 48 horas após eluição dos lipossomos em Sephadex. $0,2 \mathrm{ml} \mathrm{NaOH} 0,5 \mathrm{~N}$ foram adicionados a $4 \mathrm{ml}$ da fração 6 diluída $10 \mathrm{x}$ (Fig. 26A) . Sensibilidade de $30 / 8$. 


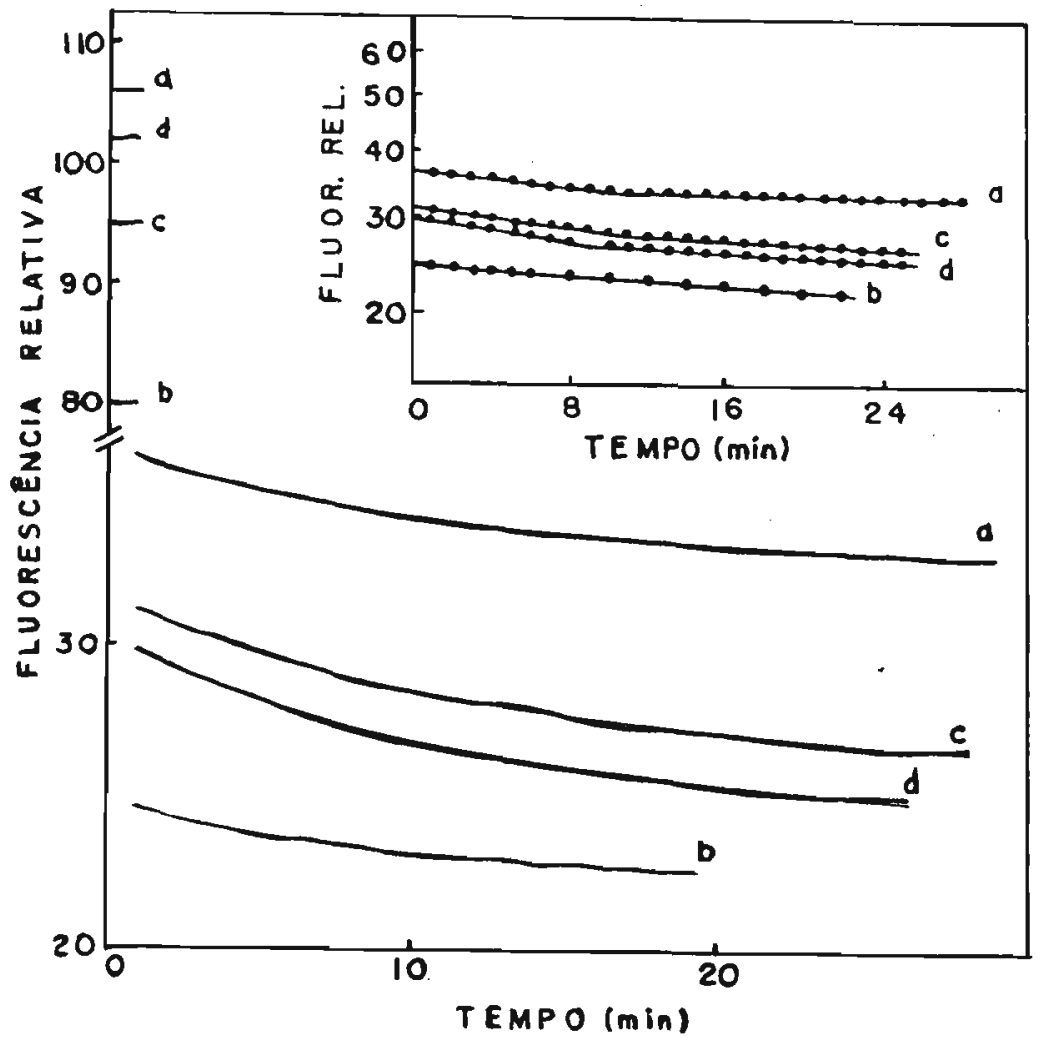

FIGURA 30 - (A) Transientes de fluorescência de 2 AP incorporada a lipossomos grandes de DODAC correspondentes à imposição de um gradiente de $\mathrm{pH}$ de 2,2 unidades ( $\mathrm{pH}$ inicial $=5,8 ; \mathrm{pH}$ final 8,0$)$. Li possomos grandes de DODAC foram preparados em $\underline{u}$ ma mistura de água e $2 \mathrm{AP} 10^{-2} \mathrm{M}$ ajustado a $\mathrm{pH}$ 5,8 . O injetado obtido nessa mistura foi filtrado em Sephadex G-25 (eluição com água tambẻm ajustada a pH 5,8) obtendo-se um pico de fluores cência e de DODAC junto à fração 4 . Essa fração 4 foi diluída tomando-se $0,2 \mathrm{ml}$ e adicionando-se $2,0 \mathrm{ml}$ de āgua $\mathrm{pH} 5,8$ (essa fração 4 diluída será chamada de FD). Diferentes alíquotas de FD foram novamente diluídas e submetidas a um mesmo gradiente de $\mathrm{pH}$ de 2,2 unidades pela adição de $0,005 \mathrm{ml}$ de $\mathrm{NaOH} 0,20 \mathrm{M}$. (a) $0,1 \mathrm{ml}$ de $\mathrm{FD}+1,9 \mathrm{ml}$ $\mathrm{H}_{2} \mathrm{O} \mathrm{pH} \mathrm{5,8;} \mathrm{(b)} 0,2 \mathrm{ml}$ de $\mathrm{FD}+2,0 \mathrm{ml} \mathrm{H}_{2} \mathrm{O} \mathrm{pH}$ 5,8; (c) $0,3 \mathrm{ml}$ de $\mathrm{FD}+1,7 \mathrm{ml}$ de $\mathrm{H}_{2} \mathrm{O} \mathrm{pH} 5,8 ;$ (d) $0,4 \mathrm{ml}$ de $\mathrm{FD}+1,6 \mathrm{ml}$ de $\mathrm{H}_{2} \mathrm{O} \mathrm{pH}$ 5,8. Sensibilidades do fluorimetro em que foram obtidos os transientes de fluorescência foram : (a) $100 / 5$; (b) $30 / 10$; (c) $30 / 7$; (d) $30 / 4$. Concentrações finais de DODAC na cubeta, em $\mathrm{mM}$, foram : (a) 0,06 ; (b) 0,10 ; (c) 0,16 ; (d) 0,22 . (B) Logarítmo da fluorescência contra temo para as mesmas cinéticas (a), (b), (c) e (d) obtidas em (A). 


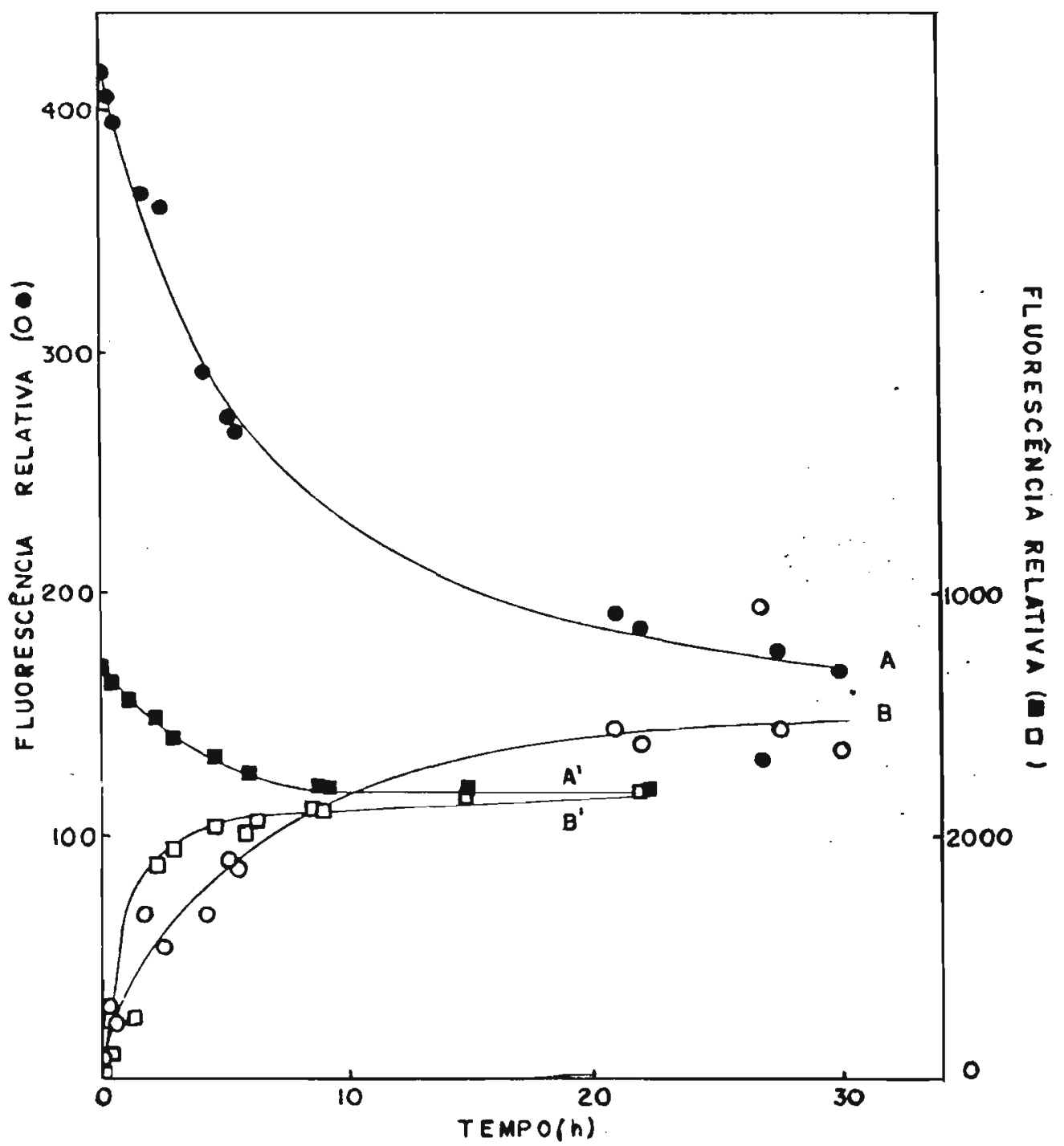

FIGURA 31 - Permeação de 2 AP atravēs de lipossomos grandes de DODAC $0,33 \mathrm{mM}$ em câmara de diâlise de equilíbrio. Frações 4 e 5 eluídas em Sephadex G-25 a $\mathrm{pH} 5,8$ foram levadas a $10 \mathrm{ml}$ e colocadas no lado A de uma câmara de diálise de equilíbrio contra $10 \mathrm{ml}$ de $\mathrm{H}_{2} \mathrm{O}$ a $\mathrm{pH} 5,8$ no lado B. Para controle, $1 \mathrm{ml}$ de $2 \mathrm{AP} 10^{-2} \mathrm{M}$ a pH 5,8 foi levada a $10 \mathrm{ml} \mathrm{em}$ $\mathrm{H}_{2} \mathrm{O} \mathrm{pH} 5,8$ e colocada no lado $\mathrm{A}^{\prime}$ contra $10 \mathrm{ml}$ de $\mathrm{H}_{2}^{2} \mathrm{O}$ a $\mathrm{pH} 5,8$ no lado $\mathrm{B}^{\prime}$. 
Para se verificar se a cinética de fluorescên cia obtida dependia da concentração de DODAC ao se estabele cer um dado gradiente de $\mathrm{pH}$ atravēs das paredes lipossomais foram feitos testes de adição de $\mathrm{NaOH} 0,25 \mathrm{~N} 4$ horas apōs separação entre 2 AP livre e 2 AP incorporada a vãrias concentrações de DODAC, (Fig. $30 \mathrm{~A}, \mathrm{~B})$. Novamente foram obtidas cinéticas bifásicas que independeram da concentração de DODAC. Repetindo os mesmos testes a várias concentrações de DODAC 48 horas após a separação entre a 2 AP livre e a 2 AP incorporada não mais foram obtidas cinēticas de fluorescências mostrando a reprodutibilidade do fenômeno anteriormente ilustrado pelas Figs. 27A ( 4 horas) e 28 (48 horas).

Na Fig. 31 mostramos resultados obtidos em câa mara de diālise de equilíbrio ilustrando a permeação da 2 AP incorporada a lipossomos grandes de DODAC ao longo do tempo.

2.4.1. Mudança da absorbância de uma mistura de corantes indicadores de $\mathrm{pH}$.

A mudança temporal da absorbância (610nm) observada após adição de ācido ou base a lipossomos de DODAC contendo uma mistura de corantes indicadores de $\mathrm{pH}$ estão na Fig. 32 .

A reprodutibilidade do fenômeno foi testada com outra amostra de 1ipossomos $10 \mathrm{mM}$ DODAC nas mesmas con dições, (Fig. 33). Analogamente às cinēticas de fluorescên 


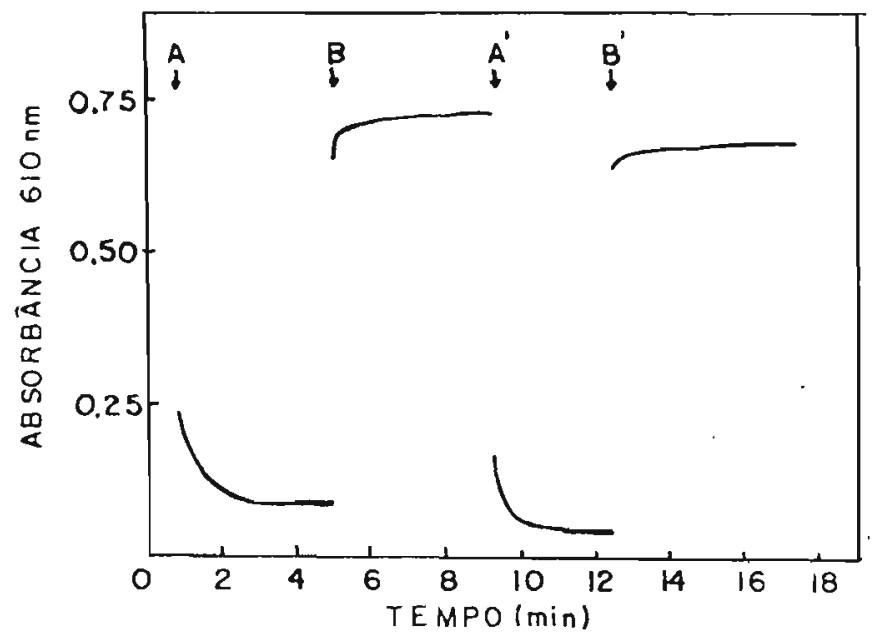

FIGURA 32 - Transientes de absorbância de uma mistura de tintas indicadoras de $\mathrm{pH}$ incorporadas a liposso mos grandes de DODAC $10 \mathrm{mM}$ após altera ção do $\mathrm{pH}$ extralipossomal. (A) e (A') : adição de $0,01 \mathrm{ml}$ de $\mathrm{HCl} 0,95 \mathrm{M}$; (B) e (B') : adição de $0,01 \mathrm{ml}$ de $\mathrm{NaOH} 0,466 \mathrm{M}$. Adições de ácido ou base a $0,7 \mathrm{ml}$ de lipossomos grandes de DODAC foram fei tas simultaneamente na cubeta de referência $\overline{\mathrm{e}}$ na cubeta da amostra.

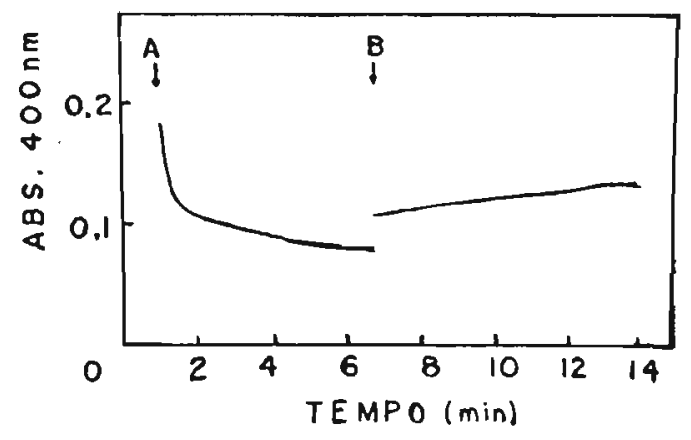

FIGURA 33 - Transientes de absorbância a $610 \mathrm{~nm}$ após a adição de $0,005 \mathrm{ml}$ de $\mathrm{HCl} 0,95 \mathrm{M}$ (A) ou $0,005 \mathrm{ml}$ de $\mathrm{NaOH} 0,466 \mathrm{M}$ (B) a lml de lipossomos grandes de DODAC $10 \mathrm{mM}$ contendo tintas $(\mathrm{AB}+\mathrm{VB})$ indicado ras de $\mathrm{pH}$. 
cia da $2 \mathrm{AP}$, as cinéticas obtidas com a mistura de corantes indicadores de pH também resultaram bifásicas (Fig. 34).

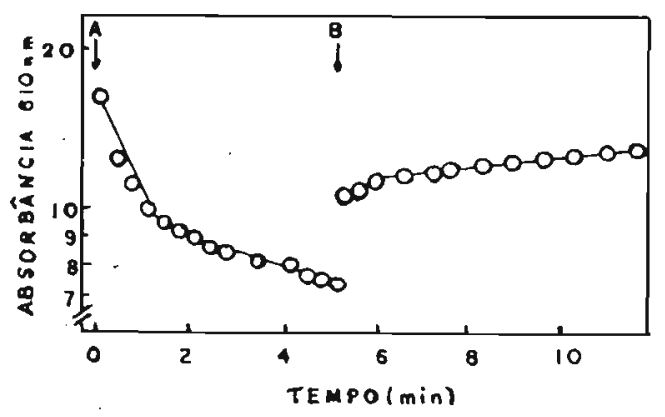

FIGURA 34 - Logarítmo da absorbância a $610 \mathrm{~nm}$ contra o tempo para as cinéticas de absorbância da Fig. 33. Após adição de ácido (A); após a adição de base (B) .

Registros de espectros de absorção antes e depois. da adição de ácido ou base mostram deslocamento dos máximos de absorção em re lação aos mãximos obtidos para a mistura de tintas em tampão fosfato e em ausência de lipossomos (Fig. 35).

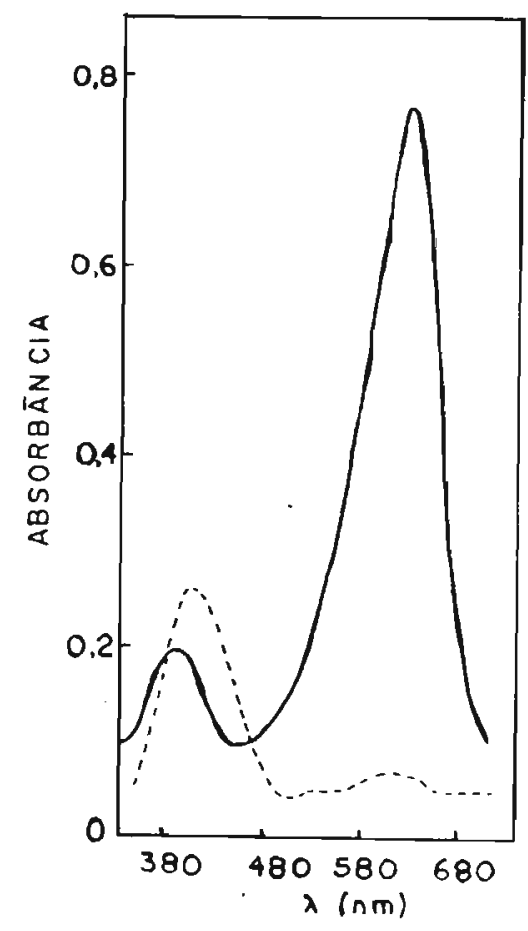

FIGURA 35 - Espectros de absorção obtidos para tintas indica doras de $\mathrm{pH}$ em presença de lipossomos grandes de DODAC $10 \mathrm{mM}$ antes $(-)$ e depois (--) da adição de $0,005 \mathrm{ml}$ de $\mathrm{HCl} 0,95 \mathrm{M}$. 
3. OBTENÇÃO DE LIPOSSOMOS GRANDES DE DCP (Dicetil fosfato de $\mathrm{Na}^{+}$).

Com a finalidade de se averiguar se seria pos sível estender o método de obtenção de lipossomos grandes de DODAC a outros anfifilicos tentamos obter lipossomos grandes de DCP de maneira anāloga à preparação dos lipossomos grandes de DODAC (vide "Material e Métodos"). Conforme já verificado por Mortara (1978), esse anfifilico pode formar vesiculas pequenas $\left(\sim 300 \mathrm{~A}^{\mathrm{O}}\right.$ de diâmetro) por dispersão ultrasônica de concentrações de DCP da ordem de lmM. Vesiculas sonicadas de DCP mostraram-se instáveis a pH's menores que 7,4 (Mortara, 1980). Assim, padronizamos uma solução a quosa a pH 8,2 como o meio no qual seria feita a injeção da solução clorofórmica de DCP.

A determinação do volume interno (V) foi feita utilizando-se $\left({ }^{14} \mathrm{C}\right)$-sacarose como marcador hidrossolúvel do comportamento aquoso interno. $V$ foi igual a $13,4 \pm 4,0$ $1 / \operatorname{mol}(n=4) \quad(F i g \cdot 36 A)$.

Para que esses dados de $V$ sejam realmente uma medida do volume do compartimento aquoso interno, devem ser verificadas 2 condições : 1) sacarose deve ser impermeante; 2) sacarose não deve ser apreciávelmente adsorvida na bicamada de DCP. Recromatografias de frações eluídas da coluna resultam na obtenção de um único pico de radioati vidade e de fosfato em torno do volume vazio, o que sugere que sacarose seria impermeante (Fig.36B). Por outro lado, a adição de $\left({ }^{14} \mathrm{C}\right)$-sacarose a uma preparação de lipossomos 
grandes de DCP seguida de filtração em Sephadex G-25 para separação de $\left({ }^{14} \mathrm{C}\right)$-sacarose adsorvida e $\left({ }^{14} \mathrm{C}\right)$-sacarose 1 ivre resulta na obtenção de um ünico pico de radioatividade em torno do volume interno da coluna e de um único pico de fosfato em torno do volume vazio da coluna, o que sugere que sacarose não seria adsorvida pela bicamada de DCP (Fig. 36 C) .

Além disso, lipossomos grandes de DCP compor taram-se como osmômetros com relação à sacarose, o que mais uma vez demonstra que sacarose é um soluto impermeante e que os lipossomos grandes de DCP são sistemas fechados (Fig. 37) . 


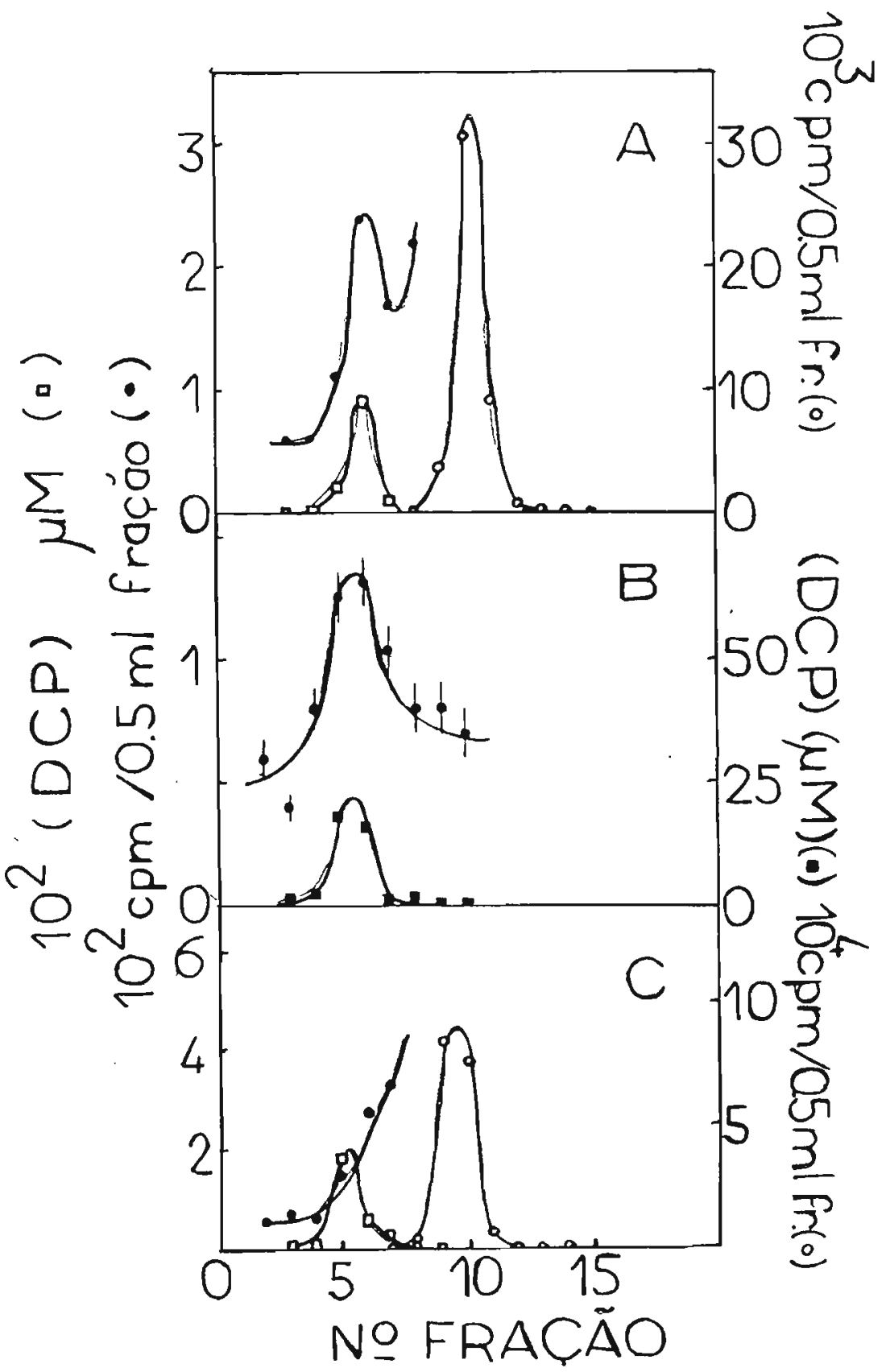

FIGURA 36 - Perfis de eluição de radioatividade ou de DCP em coluna de Sephadex G-25 (15,0 X $1,4 \mathrm{~cm})$ previamente saturada com lipossomos grandes de DCP. (A) Separação entre $(14 \mathrm{C})$-sacarose livre e in-
corporada em lml de lipossomos grandes de DCP $0,53 \mathrm{mM}$. Volume interno calculado correspondeu a $13,31 / \mathrm{mol}$. (B) Recromatografia de $(0,5 \mathrm{ml}$ da fração $5+0,5 \mathrm{ml}$ da fração 6). (C) Cromatogra fia de $1 \mathrm{ml}$ de lipossomos grandes de DCP adicionados de $\left({ }^{4} \mathrm{C}\right)$-sacarose para controle de adsorção. 


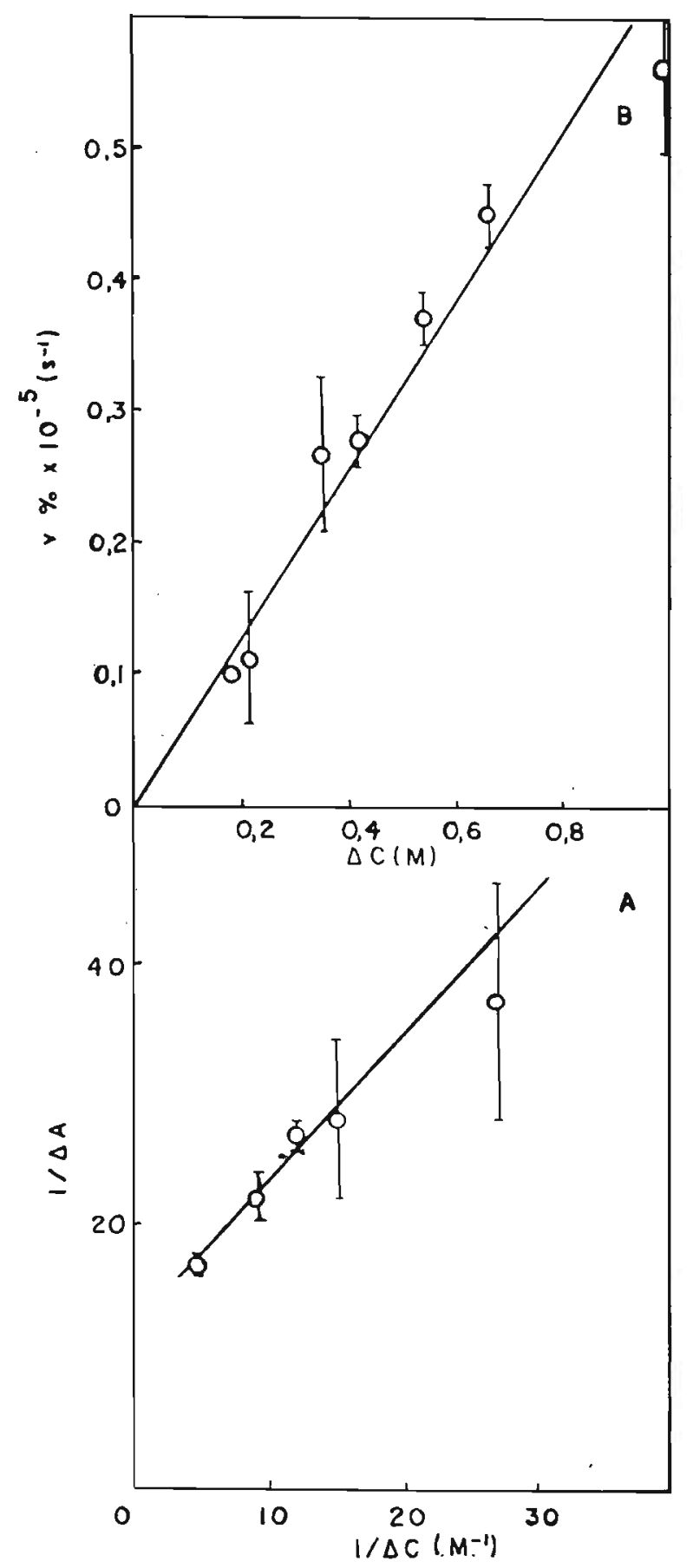

FIGURA 37 - Comportamento de osmômetro de lipossomos grandes de DCP $0,33 \mathrm{mM}$ frente à sacarose. $0,5 \mathrm{ml}$ de lipossomos grandes de DCP $0,5 \mathrm{mM}$ foram adicionados de $0,5 \mathrm{ml}$ de solução de sacarose sendo então registrados valores de absorbância a $400 \mathrm{~nm}$ em função do tempo. 
DISCUSSÃO

Nesta secção, demonstramos que lipossomos grandes de DODAC, ao contrārio do sistema constituído pelas vesículas sonicadas pequenas, podem ser mais adequados como modelos para estudos de permeabilidade através de bicamadas. Para isso, caracterizamos comparativamente ambos os sistemas quanto a algumas propriedades fisicas e funcionais. Uma propriedade bāsica de um modelo è sua capacidade de funcionar como barreira diante de certas substâncias incorporadas em seu meio aquoso interno, no caso de bicamadas fechadas. Ao mesmo tempo, substâncias hidrosollüveis impermeantes podem ser utilizadas para se determinar o volume interno de lipos somos constituidos por fosfolípides (Kornberg e McConnell, 1971; Papahadjopoulos et al., 1971) desde que não sejam apre ciavelmente adsorvidos pela bicamada fosfolipídica. Como não houve vazamento (ou preenchimento) de lipossomos grandes de DODAC com a sacarose (Fig. 13), esta resulta um solu to impermeante atravēs desse sistema. O volume interno apa rente calculado para os 1 ipossomos grandes de DODAC $(9,7 \pm$ $1,31 / \mathrm{mol}$ ) é cerca de 20 vezes maior que o valor calculado para o controle de adsorção de $\left({ }^{14} \mathrm{C}\right)$-sacarose $(0,64 \pm 0,3$ l/mol) (Tab. II). Assim, a sacarose é um marcador hidrosolúvel adequado do compartimento aquoso interno de lipossomos grandes de DODAC. Vesículas fosfolipidicas grandes, pre paradas por vaporização de éter exibem volumes internos (14 $\pm 61 / \mathrm{mol}$ ) (Deamer e Bangham, 1976) que são similares aque- 
les dos lipossomos grandes de DODAC. Consequentemente, as capacidades de incorporação desses dois sistemas são comparáveis. o volume do compartimento aquoso interno tambēm po de ser calculado com base no diâmetro obtido por microscopia eletrônica (Fig. 8), como se faz usualmente com sistemas fosfolipidicos fechados (Deamer e Bangham, 1976; Szoka e Papahadjapoulos, 1978; Enoch e Strittmatter, 1979). A área média de um monômero de DODAC em uma bicamada é $40 \AA$ (Herrmann e Fendler, 1979). Essa ārea é menor do que aquela de fosfolỉpides em estruturas comparāveis : $46-75 \AA \AA$ dependendo da temperatura e da natureza do fosfolípide (Demel e De Kruyff, 1976). Isso porque a cabeça polar hidrofí lica do DODAC é substancialmente menor que a de um fosfolíde, sendo que a repulsão eletrostātica entre as cabeças do DODAC, que tenderia a aumentar a área superficial por monõmero, seria compensada por uma extensiva condensação devida aos contraíons (Fendler, 1980). Como o diâmetro externo mé dio $(0,514 \mu)$ (Fig. 9) dos lipossomos grandes de DODAC é gran de, o número de monômeros nas monocamadas externa e interna da bicamada pode ser considerado igual. Dados de micros copia eletrônica (Fig. 8) exibem pouca evidência de estrutū ras multilamelares fechadas. Assim, assumindo uma única la mela fechada, o volume interno calculado é de $101 / \mathrm{mol}$. Es se valor é concordante com o obtido experimentalmente através de incorporação de $\left({ }^{14} \mathrm{C}\right)$-sacarose.

Vesículas sonicadas de DODAC possuem raio hidrodinâmico de $447 \AA$ (Herrmann e Fendler, 1979) e, vesículas sonicadas de fosfolípides têm 200-500 $\stackrel{\circ}{\AA}$ de diâmetro ex 
terno médio (Papahadjopoulos et al., 1980). Assumindo 300$900 \AA$ como faixa de diâmetrospara vesículas sonicadas de DODAC e $40 \AA$, para a área média por monômero (Herrmann e Fendler, 1979), o volume interno calculado é $0,15-0,451 / \mathrm{mol}$. o volume interno calculado pela incorporação de $\left({ }^{14} \mathrm{C}\right)$-sacarose $(0,33 \pm 0,20 \mathrm{l} / \mathrm{mol}) \quad$ (Fig. IlA, Tab. II) é da mesma or dem de magnitude que a adsorção externa de sacarose $(0,2 \pm$ 0,08 1/mol) (Fig. 12, Tab. II). Subtraíndo 0,20 $\pm 0,08$ 1/ mol (adsorção) de 0,33 $\pm 0,201 / \mathrm{mol}$ (adsorção e incorporação), podemos considerar $0,131 / \mathrm{mol}$ como um limite superior para o volume interno de vesículas sonicadas de DODAC, um valor praticamente idêntico ao estabelecido para vesículas sonicadas de fosfatidilserina em ausência de adsorção (Korn berg e McConnell, 1971 ; Papahadjopoulos et al., 1971) . A observada ausência de responsividade osmótica em vesículas sonicadas de DODAC após o estabelecimento de gradientes osmóticos de sacarose (Fig. 16B) também sugere um compartimen to aquoso interno extremamente pequeno. Convēm observar ain da que ausência de responsividade osmótica em vesículas so nicadas de fosfolípides já foi observada por outros autores (Johnson e Buttress, 1973). Por outro lado, foi demonstrado que vesículias unilamelares de fosfolípides com diâmetro inferior a $400 \AA$ são instáveis abaixo da $\mathrm{T}_{\mathrm{C}}$ e fundem espon taneamente para formar vesículas maiores (Suurkuusk et al."' 1976; Kantor et al., 1977; Larrabee, 1979; Schullery et al., 1980; Lichtenberg et al., 1981). No caso da dipalmitoilfos fatidilcolina (DPPC), essa fusão leva à formação de vesículas unilamelares com cêrca de $700 \AA$ de diâmetro que são es 
táveis abaixo da $T_{C}$ (Schullery et al., 1980) e que apresentam responsividade osmótica e caracteristicas calorimētricas muito similares às de lipossomos multilamelares. Segun do Lichtenberg et al. (1981), essas vesiculas de DPPC de $700 \stackrel{\circ}{\mathrm{A}}$ seriam bastante flexiveis e poderiam suportar aumentos de até duas vezes no seu compartimento aquoso interno sem qualquer vazamento do conteúdo interno. Já as vesí culas sonicadas de DPPC de diâmetro inferior a $400 \AA$ seriam esferas rígidas incapazes de responderem a gradientes osmóticos. Outra interpretação possível para a ausência de responsividade osmótica de vesículas sonicadas de DODAC que aliās, nos parece a mais adequada, seria a de um compartimen to aquoso interno constituído principalmente por āgua de hidratação, ou seja, por água ligada fortemente à bicamada que não estaria disponível para responder a gradientes osmó ticos de soluto gerados atravês da mesma. Para verificar a validade dessa interpretação podemos fazer um cálculo sim ples da proporção entre número de molēculas de ãgua no compartimento aquoso interno e número de moléculas de DODAC na bicamada interna. Vamos supor $0,13 \mathrm{l} / \mathrm{mol}$ como o volume interno de vesiculas sonicadas de DODAC (vide Tab. II). Supon do que, em cada 3 molēculas de DODAC, 2 estejam na monocama da externa da vesícula e 1 esteja na monocamada interna (De mel e De Kruyff, 1976), 0,13 1 de āgua serão limitado por $2 \times 10^{23}$ moléculas de DODAC, ou seja, $43 \times 10^{23}$ moléculas de $\mathrm{H}_{2} \mathrm{O}$ serão limitadas por $2 \times 10^{23}$ moléculas de DODAC. Final mente, fazendo a proporção, teremos cerca de 22 molēculas de água para cada molécula de DODAC da monocamada interna da 
vesícula. Ora, coincidentemente, existem dados na literatu ra que mostram que cada molēcula de fosfolípide na monocama da interna seria hidratada por 23 moléculas de água (Finer e Darke, 1974).

Nesse trabalho, os autores obtem espectros de ressonância magnētica de deuteron em sistemas binārios de $2 \mathrm{H}_{2} \mathrm{O}$ com lecitina de ovo, fosfatidiletanolamina de ovo ou fosfatidilserina de cérebro de boi na forma de sal sódico. Esses três fosfolípides estudados apresentaram diferentes comportamentos frente à hi'aratação. A fosfatidilserina na forma de sal de sódio liga 1 molécula de água em uma casca interna de hidratação (possívelmente ligada ao fosfato), mais 10 moléculas de água em torno de sua parte polar e ainda, 12 molēculas de água associadas com o íon sódio que estariam fracamente ligadas. Todas essas moléculas de āgua trocam rapidamente de posição entre si $\left(>10^{4} \mathrm{~s}^{-1}\right)$, mas trocam apenas lentamente com a água livre $\left(<10^{2} \mathrm{~s}^{-1}\right)$. Dentre os três fosfolípedes estudados, o que teria estrutura química mais próxima do DODAC seria a fosfatidilserina de sódio, já que esta teria, como o DODAC, cabeças polares carregadas e contra-íons, enquanto que a lecitina e a fosfatidiletanolamina teriam cabeças polares zwitteriônicas e, portanto, não teriam contra-ions. Assim, parece válido supor que o inte rior de vesículas sonicadas de DODAC contenha principalmente molēculas de água de hidratação. Adicionalmente, Kano e Fendler (1979), através de estudos de polarização de fluorescência de marcadores incorporados no meio aquoso interno de vesiculas unilamelares de fosfolípedes, determinaram vis 
cosidades do meio intralipossomal antes e depois de choques osmóticos. Verificam que há um substancial aumento das vis cosidades após os choques osmóticos e interpretam esse resultado em termos da natureza da āgua contida no interior dos lipossomos. Antes do choque osmótico, os marcadores fluorescentes estariam em um ambiente constituído por água livre e depois, em um ambiente mais viscoso que seria constituído por água de hidratação. Uma questão ainda em aberto seria se essa água de hidratação poderia ou não deixar o compartimento aquoso interno em decorrência da imposição de gradientes osmóticos elevados, sem desestruturação da bicamada de detergente ou de fosfolípide. Mais adiante pretendemos analisar alterações de absorbância com o tempo em 1ipossomos grandes de DODAC decorrentes de gradientes osmóticos na faixa de 500 - 1000 miliosmois para se verificar se é possível a retirada de āgua de hidratação do compartimento aquoso intravesicular.

O $\mathrm{HCl}$ é ligeiramente mais permeante que o $\mathrm{KCl}$ e, a sacarose e o $\mathrm{NaCl}$ são tão impermeantes quanto $\circ \mathrm{KCl}$ (Fig. 15). Recentemente, foi mostrado que $\mathrm{H}^{+}$permeia vesiculas de asolecitina (Clement e Gould, 1981). Dados relati vos à permeação de $\mathrm{H}^{+}$em lipossomos grandes de DODAC sugerem que essa velocidade de permeação é menor que velocidades de permeação de $\mathrm{H}^{+}$atravēs de vesículas fosfolipídicas (Ver Resultados relativos à permeação de $\mathrm{H}^{+}$a partir da Fig. 27 e comparar com dados de clement e Gould (1981)). Em Em um sistema positivamente carregado, como os lipossomos grandes de DODAC (Cuccovia et al., 1982), espera-se que a velocidade de permeação do $\mathrm{H}^{+}$seja menor que a ve- 
locidade de permeação em vesículas de asolecitina neutras ou negativamente carregadas. Entretanto, $\mathrm{H}^{+}$permearia lipossomos grandes de DODAC mais depressa que $\mathrm{K}^{+}$, um ion de dimensões bem maiores. Dados de permeabilidade absoluta pạ ra a sacarose (Fig. 11, 12,13) demonstram que a sacarose é impermeante através de lipossomos grandes de DODAC. Assim, $\mathrm{KCl}$ e $\mathrm{NaCl}$ são também impermeantes e o $\mathrm{HCl}$ é ligeiramente permeante, em termos absolutos. Resumindo, lipossomos gran des de DODAC comportam-se como barreira diante de sacarose, de $\mathrm{NaCl}$ e de $\mathrm{KCl}$. Vamos agora, analisar o comportamento des se sistema em relação à permeação de āgua.

Em esferas de lecitina, Edelberg (1953) observou alterações de volume após alterações da osmolaridade do meio. Bangham et al. (1965) previram, à partir de estudos de permeação de ions e de água em suspensões de lecitina, que um efeito osmótico poderia vir a ser observado nessa pre paração. Rendi (1967), usando fosfolípides extraídos de mi tocôndria que se encontravam presumivelmente na forma de cristais lïquidos em uma mesofase esmética, mostrou que essas suspensões de fosfolipedes respondiam a gradientes osmōti cas e seguiam a lei de Boyle van'thoff, quantificando pela primeira vez o fenômeno osmótico nessa preparação. Como ○ $\mathrm{NaCl}$. não era adequado como gerador de efeito osmótico devido à indução de precipitação das "micelas" de fosfolípedes (Robim e Thomas, 1963; Abramson et al., 1964), Rendí (1967) usou um não-eletrólito : a sacarose. Bangham et al. (1967) mostraram que suspensões de lecitina ou de lecitina e ácido fosfatídico (96:4) comportavam-se como osmômetros quase 
perfeitos para solutos como a glicose, a sacarose, o manitol e sais de metais alcalinos. O critério para verificação de comportamento osmométrico foi também a lei de Boyle van't Hoff segundo a qual o volume final de uma dispersão previamente submetida a um gradiente osmótico deve ser inversamente proporcional à concentração de soluto utilizada para gerar o gradiente. Formalmente, essa lei pode ser expressa como: $\mathrm{V}=\mathrm{k} / \mathrm{C}+\mathrm{V}_{\mathrm{C} \rightarrow \infty}$ onde $\mathrm{V}:$ volume total final dos lipossomos que pode ser medido como o volume de um "pel let" obtido por centrifugação de dispersão menos o volume intersticial determinado com o auxílio de um marcador radio ativo do meio extralipossomal adicionado à suspensão antes da centrifugação (insulina ou sacarose marcados); $C$ : con centração do soluto; $V_{c \rightarrow \infty}=$ espaço osmōtico morto, ou seja, - volume lipossomal após saída de toda a água por aplicação de um gradiente de concentração infinita de soluto.

A determinação do volume final da suspensão a pós aplicação do gradiente osmótico pode ser feita pelo mé todo fotomētrico (Rendí, 1967; Bangham et al., 1967), uma vez demonstrada uma relação linear entre o volume de pellet (em $\mathrm{mm}^{3} / \mu \mathrm{mol}$ de fosfolípede, por exemplo) e o recíproco da absorbância. Assim, à partir de registros de $A_{f}$ (absorbância final da suspensão à qual foi aplicado um dado gradiente osmóticol, pode-se verificar se $1 / A_{f}$ é proporcional ao recỉproco da concentração do soluto utilizado como gerador de efeito osmótico.

Para determinar um coeficiente de permeação osmōtica de água, Bangham et al . (1967) estimaram a varia- 
ção inicial de volume com o tempo, isto é, $\left.\frac{d V}{d t}\right|_{t \sim 0}$, que daria uma medida da velocidade inicial de movimentação de água induzida por efeito osmótico $:\left.\frac{d V}{d t}\right|_{t \sim 0}=\left.\frac{d(1 / A)}{d t}\right|_{t \sim 0} \cong$ $-\frac{1}{A_{0}^{2}} \frac{d A}{d t} \quad t \sim 0$ onde $A_{0}$ : valor constante de absorbancia de $\underline{\mathrm{V}} \mathrm{ml}$ de dispersão mais $\underline{\mathrm{v}} \mathrm{ml}$ de solução isoosmolar com o com partimento intralipossomal, sendo que $\underline{V} \mathrm{ml}$ de dispersão eram adicionados de $\underline{\mathrm{v}} \mathrm{ml}$ de solução hipotônica para obtenção do efeito osmótico; $\left.\frac{d A}{d t}\right|_{t \sim 0}=$ coeficiente angular da reta* tangente à curva absorbância (A) versus tempo ( $t$ ) no instan te em que se iniciou seu registro $(t \sim 0)$.

A partir de dV/dt e da determinação de área superficial externa total da dispersão (através de adsorção estequiométrica de $\mathrm{UO}_{2}{ }^{+}$), o coeficiente de permeabilidade osmótica de água foi estimado e comparado com valores já existentes para outros sistemas - modelo de membrana.

Nosso critērio para identificar comportamento de osmômetro foi também a lei de Boyle van't Hoff que impli ca em linearidade para os gráficos de $1 / A_{f}$ contra $1 / \Delta C$ e de $v$ \& contra $\Delta C$. A expressão que define "velocidade inicial de encolhimento" é a de Bangham et al. (1967): $\left.\frac{d(1 / A)}{d t}\right|_{t \sim 0}$ $=-\left.\frac{1}{A_{0}^{2}} \frac{d A}{d t}\right|_{t \sim 0}$. A definição que utilizamos é a de Blok et $\underline{\text { all. }}$. (1976) onde $v \circ=-\frac{1}{A_{O}} \frac{d A}{d t} t \sim 0$ que, matematicamente, não é correta. Todavia, como $A_{0}$ é um valor praticamente constante para uma mesma concentração final de DODAC e para um mesmo soluto gerador de efeito osmótico, os perfis das curvas obtidas com os parâmetros de Blok et al. (1976) são os mesmos que os obtidos segundo Bangham et al. (1967) (dividindo todos os pontos de uma curva por uma constante não alteramos o 
perfil da curva). Por motivo anālogo, pode-se usar $1 / A_{f}-A_{O}$ ou $\left(1 / A_{O}-I / A_{f}\right) A_{O} \times 100$ em função de $1 / \Delta C$ para se expressar 0 : comportamento de $1 / A_{f} \operatorname{com} 1 / \Delta C$.

O sistema constituído por lipossomos grandes de DODAC pode ser descrito pela lei de Boyle van't Hoff para a faixa de concentração de $0-50 \mathrm{mM}$ de $\mathrm{KCl}$ (Fig. 17C e D). A não-linearidade dos parâmetros osmométrí cos para concentrações alēm dessa faixa pode ser explicada pela susceptibilidade dessas preparações a sais (Tran et al., 1978; Fendler, 1980) e consequentes alterações de absorbân cia com o tempo decorrentes de fenômenos não-osmóticos (flo culação ou fusão) . Para vesículas sonicadas de DODAC foi descrito comportamento de osmômetro em relação ao $\mathrm{KCl}$ (Kano et al.., 1979). Todavia, esses dados são criticáveis por dois motivos principais : 1) parâmetros osmométricos cal culados não são representativos (determinações isoladas e não, valores médios); 2) efeitos induzidos pelo $\mathrm{KCl}$ como flo culação ou agregação podem ter sido interpretados como enco lhimento. Além disso, dados de absorbância derivada do espalhamento de luz para vesículas sonicadas de DODAC demonstram a ocorrência de agregação por adição de sal (Fendler, comunicação pessoal). Assim, vesículas sonicadas de DODAC não se comportaram como osmômetros em relação ao $\mathrm{KCl}$ ao lon go da mesma faixa de concentrações de DODAC e de $\mathrm{KCl}$, na qual lipossomos grandes de DODAC apresentaram esse comporta mento (Fig. 17A e B). Para explicar esse resultado devem ser considerados os seguintes fatores : 1) o nümero de vesí culas na dispersão sonicada é maior que o número de vesícu 
las na dispersão injetada para uma mesma concentração de DODAC; a área superficial total e a secção de choque disponível para interações intervesiculares são maiores para a dispersão sonicada (considerando uma mesma ārea superficial por monômeros nas duas dispersões, o mesmo número de monôme ros nas duas dispersões, uma relação $2: 1$ entre o número de monômeros na monocamada externa e na interna das vesículas sonicadas e $1: 1$, para o número de monômeros na monoca mada externa e interna dos lipossomos grandes de DODAC, uma relação entre os raios das sonicadas e das grandes de 1/20, é possível calcular um número de vesículas pequenas cêrca de 100 vezes maior que o nümero de vesículas grandes); 2) estabilidade intrínseca da dispersão constituída pelas vesí culas sonicadas é menor que a estabilidade da dispersão cons tituida pelos lipossomos grandes de DODAC, devido ao menor raio de curvatura das sonicadas que diminui a interação hidrofóbica entre cadeias hidrocarbônicas adjacentes ( $T_{C}$ para lipossomos grandes de DODAC é maior que a $T_{C}$ para vesículas sonicadas de DODAC (Fig. 10, Tab. I), um dado que também corrobora a maior instabilidade das vesículas sonicadas de DODAC); 3) maior velocidade de difusão para vesículas sonica das de DODAC em relação aos lipossomos grandes de DODAC, des de que particulas menores difundem mais depressa que as maio res.

A transição de fase dos lipossomos grandes de DODAC resultou mais nítida que a transição de fase das vesî culas sonicadas, ou seja, ocorreu em uma faixa mais estreita de temperaturas. Por cooperatividade, entende-se a faci lidade sempre crescente com que mais desordenados são atin- 
gidos por moléculas adjacentes (Zimm e Bragg, 1959). No es tado gel, as cadeias acila estão numa configuração estendida e no estado líquido-cristal, estão totalmente desordenadas (Lee, 1977). Como a liberdade de rotação em torno das ligações C-C em uma dada cadeia acila de uma molécula requer que os lípides vizinhos estejam fluídos, por simples razões estēricas, a transição serā cooperativa. Como as ve sículas obtidas por injeção são maiores que as obtidas por sonicação, a transição de fase das primeiras será mais abrụp ta que a das últimas. Uma vez iniciada a fusão em um vazio do retículo ou em um defeito qualquer da bicamada de uma ve sícula, todas suas molēculas fundem cooperativamente.

o fato de vesículas sonicadas fundirem a temperaturas inferiores às dos lipossomos grandes de DODAC (Tab. II) sugere que as sonicadas teriam uma configuração abaixo da transição de fase que seria mais instável que a configuração dos lipossomos grandes de DODAC. Possívelmente, essa maior instabilidade seria decorrente do menor raio de curva tura com consequente diminuição de interação hidrofóbica en tre molēculas adjacentes nas sonicadas em relação aos lipos somos grandes por motivos geométricos e estéricos (Israelachvilii et al., 1980).

Desde que o volume molar de DODAC na fase 1iquido-cristal é maior que o volume molar de DODAC na fase gel, em analogia com o comportamento de sistemas fosfolipidicos, um domínio na fase líquido-cristal estará sob compressão enquanto que um domínio na fase gel estará sob tensão (Lee, 1977). Isso explicaria a pronunciada histerese 
obtida nas curvas de transição de fase de lipossomos grandes de DODAC ou de vesículas sonicadas de DODAC (Fig. 10). Dispersões aquosas de fosfatidilserinas não apresentam curvas superpostas de aquecimento e resfriamento; histerese sendo um fenômeno mais provável para lípides carregados(Mac Donald et al., 1976).

Recentemente, Takemoto et al. (1981) descreve ram o efeito do tamanho lipossomal sôbre os parâmetros de transição de fase de lipossomos unilamelares de fosfatidilcolina e de dipalmitoilfosfatidilcolina. Verificaram que, tanto o ponto médio quanto a nitidez da transição aumentavam com o tamanho dos lipossomos, um resultado totalmente $\underline{\text { a }}$ nálogo ao que obtivemos para as vesículas sonicadas e os li possomos grandes de DODAC. Além disso, observaram desapare cimento da pré-transição em todas as preparações constituídas por lipossomos unilamelares, mesmo os maiores, sugerindo que a prē-transição envolveria interações entre lamelas adjacentes. A ausência de pré-transição (Fig. 10) pode, por tanto, significar que tanto os lipossomos grandes de DODAC quanto as vesículas sonicadas de DODAC são unilamelares.

Lipossomos fosfolipĩdicos são permeãveis à água e responsivos a gradientes osmóticos tanto acima quanto abaixo da $\mathrm{T}_{\mathrm{C}}$ (Lee, 1977). Em torno da 'T, uma alteração acentuadamente reduzida de absorbância apơs um choque osmótico pode ocorrer devido a permeabilidades

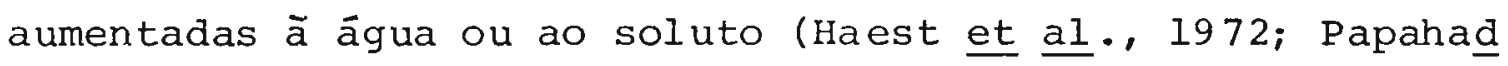
japoulos et al., 1973; Inoue, 1974; Nichols e Miller, 1974; Blok et al., 1975). Lipossomos grandes de DODAC, em parti- 
cular, comportaram-se em torno de $\mathrm{T}_{\mathrm{C}}$ como lipossomos de dimiristoilfosfatidilcolina (Blok et al., 1976) atingindo um mínimo para a extensão total de encolhimento e aumentando abruptamente a velocidade inicial de encolhimento (Fig.22). Esse comportamento pode ser explicado, como para os liposso mos de dimiristoilfosfatidilcolina, por uma permeabilidade aumentada à āgua e ao $\mathrm{KCl}$ em torno da $\mathrm{T}_{\mathrm{C}}$ decorrente da formação de poros estatisticos nas regiões de interfase, ou se ja, nas regiões entre domínios gel/líquido-cristal.

Fenômenos puramente osmóticos de encolhimento após estabelecimento de hipertonicidade no meio extralipossomal deveriam ser reversíveis. Assim, alterações de absorbância com o tempo decorrentes de hipertonicidade no meio extralipossomal tambēm seriam reversíveis desde que se revertesse o gradiente osmōtico inicialmente estabelecido e desde que essas alterações de absorbância estivessem refletindo encolhimento lipossomal. A reversibilidade osmótica exibida pelos lipossomos grandes de DODAC (Fig. 23, 24) con. fìrma a natureza vesicular proposta para essa preparação. A lém disso, poder-se-ia imaginar que um critério adequado pa ra estabilidade da dispersão frente a sais fôsse a reversão do efeito osmōtico. Fenômenos não-osmōticos deveriam ser, nesse caso, irreversíveis. Assim, ao se aumentar a concentração salina os efeitos de floculação e/ou agregação induzidos pelo sal se manifestariam e não se obteria reversão do efeito por diluição. Os resultados obtidos mostram que não é esse o caso (Fig. 25), uma vez que fenômenos não-osmó ticos também parecem reverter com a diluição. As cinéticas 
bifāsicas de reversão obtidas em C e D (Fig. 26) sugerem que fenômenos não osmóticos também seriam reversíveis com a diluição. A fase inicial räpida corresponderia à reversão dos fenômenos não-ósmóticos enquanto que a fase posterior mais lenta corresponderia à reversão do encolhimento.

Volumes internos de vesículas sonicadas de DODAC ou de lipossomos grandes de DODAC calculados através da incorporação de 2 AP resultaram sempre menores que os ob tidos atravēs da incorporação de $\left({ }^{14} \mathrm{C}\right)$-sacarose (vide Fig. 26) - Além disso, cinéticas de permeação de $\cdot \mathrm{OH}^{-}$em fraÇões eluídas de coluna que continham lipossomos grandes de DODAC incorporando 2 AP tornavam-se cada vez menos detectáveis com o tempo. Assim, 4 horas apōs a separação 2 AP 1 ivre/2 AP incorporada era possível detectar uma cinētica bas tante pronunciada de permeação de $\mathrm{OH}^{-}$(Fig. 27A), ao pas so que 48 horas após essa mesma separação, não era possível detectar uma cinética apreciável de permeação de $\mathrm{OH}^{-}$(Fig. 28). Esses dados sugerem que 2 AP estaria permeando as paredes dos lipossomos de DODAC. A confirmação dessa hipótese está na Fig. 31 onde verificamos que 2 AP incorporada em lipossomos grandes de DODAC é capaz de permear esses lipossomos e de chegar ao lado $B$ de uma câmara de diálise de equilíbrio. Uma discussão cabível no caso seria referente à espécie de 2 AP que efetivamente está permeando o lipossomo. Em torno do pK aparente, há um equílibrio entre 2 AP neutra e 2 AP positivamente carregada. Assim, a distribuição de ácidos e bases fracas atravēs de membranas irá depender do gradiente de pH existente através das mesmas. Esse efeito 
vem sendo usado para se medir gradientes de $\mathrm{pH}$ em mitocôndria (Addanki et al., 1968), em cloroplastos (Rottenberg et al., 1972), em lisossomos (Goldman e Rottenberg, 1973), em grânulos de cromatina (Johnson e Scarpa, 1976) e em liposso mos (Deamer et al., 1972) com aminas como a metilamina e a 2-aminoacridina. Em lipossomos preparados com o interior ā cido em relação ao tampão externo, catecolaminas adicionadas ao meio externo podem se concentrar. Assim, gradientes de $\mathrm{pH}$ poderiam contribuir para a concentração de catecolami nas em sítios de armazenamento subcelulares. Lipossomos de fosfatidilcolina de ôvo preparados por vaporização de éter resultam impermeantes à forma carregada das aminas e permeantes à forma neutra sendo capazes de acumular concentrações crescentes de catecolaminas com o aumento dos gradientes de pH através das paredes lipossomais (Nichols e Deamer, 1976). Assim, supondo permeação da forma neutra de $2 \mathrm{AP} e$ não-permeação da forma positivamente carregada è possível interpretarmos os resultados obtidos de forma coerente. A $\mathrm{pH} 5,8$, um pouco abaixo do $\mathrm{pK}$, há uma concentração de $2 \mathrm{AP}$ carregada ligeiramente superior à concentração de 2 AP neu- . tra tanto no interior quanto no meio exterior aos lipossomos. Ao iniciarmos a separação entre a 2 AP livre e a 2 AP incorporada na coluna, como a forma neutra incorporada é permeante, jā se inicia, desde o topo da coluna, um certo vazamento de 2 AP neutra. Como a 2 AP neutra permeia, o equi líbrio 2 AP neutra/2 AP carregada dentro do lipossomo é des locado no sentido de se obter mais 2 AP neutra no interior do lipossomo a qual, por sua vez, também irä vazar. Assim, 
uma vez terminada a separação na coluna, teremos uma concen tração de 2 AP incorporada nos lipossomos que será sempre inferior àquela que foi incorporada ao injetarmos uma soluÇão clorofórmica de DODAC em āgua contendo 2-aminopiridina, - que concorda com os valores subestimados de volume interno dos lipossomos grandes de DODAC obtidos por incorporação de 2 AP. A adsorção de 2 AP à bicamada resultou praticamen te nula $(0,01$ 1/moles) em relação ao volume interno calculado pela o de incorporação (1,6 1/mol) (Fig. 24 e 26B). As sim, 2 AP seria um marcador hidrossolúvel adequado do compartimento aquoso interno por não ser adsorvido e não-ade quado por ser permeante.

Tanto a alteração de fluorescência da 2 AP co mo a mudança de absorbância da mistura de tintas induzidas por gradiente de $\mathrm{pH}$ através das vesículas de DODAC apresentaram um caráter bifásico (Fig. 30 e 34). Portanto, esse caráter parece independer do método de detecção do fenômeno. Por outro lado, em ambos os métodos foram obtidas alterações dentro de uma mesma ordem de grandeza quanto à escala de tempos, o que também sugere que o mesmo fenômeno foi de tectado por ambos os métodos. Considerando que os marcado res utilizados nos dois métodos são moléculas completamente diferentes ( 2 AP abaixo de seu pK é positivamente carregada enquanto que as tintas $A B$ e VB são negativamente carregadas; 2 AP é uma molēcula pequena enquanto que as tintas são molé culas relativamente grandes), torna-se dificil atribuir as cinēticas obtidas a propriedades inerentes aos marcadores. Além disso, as cinéticas obtidas são equiparāveis às obtidas 
por Clement e Gould (1981) para a permeação de prōtons em vesículas grandes de asolecitina. O fato de nossas cinéticas serem mais lentas (embora da mesma ordem de grandeza) que as desses autores pode significar que o sistema constituído pelos lipossomos grandes de DODAC seria menos permean te $\mathrm{a} \mathrm{H}^{+} / \mathrm{OH}^{-}$que o sistema constituído pela asolecitina.

As tintas indicadoras de $\mathrm{pH}$ possívelmente estão fortemente adsorvidas à bicamada devido aos seus grupos sulfônicos negativos $(\mathrm{pK} \sim 2,0)$. Dessa forma, as cinéticas bifásicas obtidas poderiam ser devidas a : 18). uma passagem rāpida de $\mathrm{H}^{+} / \mathrm{OH}^{-}$pela bicamada que modificaria a absorção da tinta adsorvida na bicamada; 2\%) um preenchimento do com portamento aquoso interno $\mathrm{com} \mathrm{H}^{+} / \mathrm{OH}^{-}$mudando a absorção da tinta contida no mesmo. Todavia, como no caso da 2 AP em que o controle de adsorção de 2 AP ã bicamada mostrou uma adsorção praticamente nula foi obtido também um fenômeno bi fásico, exclue-se essa possibilidade de que a fase mais rápida da cinética seja devida à passagem de $\mathrm{H}^{+} / \mathrm{OH}^{-}$através da bicamada.

Outra possibilidade de interpretação das cinẹ tiaas obtidas seria a indução de floculação e/ou encolhimen to dos Iipossomos grandes de DODAC por adição de $\mathrm{NaOH}$ e/ou HCl. Floculações e/ou encolhimentos dos lipossomos resulta riam em aumentos do espalhamento de luz das dispersões e consequente diminuição da fluorescência de 2 AP detectada. Entretanto, no caso das tintas indicadoras de $\mathrm{pH}$, essa possibilidade está excluída uma vez que a cubeta de referência contém lipossomos sen tintas que são submetidos às mesmas 
adições de $\mathrm{NaOH} / \mathrm{HCl}$ que a cubeta da amostra. Isso garante que efeitos de encolhimento e/ou floculação não estejam con tribuindo para os transientes de absorbância registrados.

Em conclusão, cinēticas de alteração de fluorescência da 2 AP e de alteração de absorbância das tintas podem ser interpretadas qualitativamente como cinéticas de permeação de $\mathrm{H}^{+} / \mathrm{OH}^{-}$atravês de lipossomos grandes de DODAC. Um estudo quantitativo do fenômeno vem sendo objeto de pesquisas sistemáticas em nosso labotarório com a finalidade de se estabelecer a dependência de constantes de velocidade aparentes do fenômeno com o gradiente de concentração de prótons e com a faixa de pH's em que se situam esses gradientes.

Provavelmente, os dois aspectos mais interes santes desse trabalho são : 1) a introdução de um critério confiāvel de estabilidade de vesículas sintēticas em rela ção a sais, isto é, a determinação de faixas de concentração de sal nas quais o comportamento de osmômetro ocorre; 2) a perspectiva de empregar métodos disponíveis para fosfolipides para se obter novos sistemas sintéticos constituídos por detergentes nos quais propriedades funcionais de membra nas podem ser sistemāticamente testadas. 
RESUMO

Lipossomos de cloreto de dioctadecildimetilamonio (DODAC) com $0,51 \mu$ de diâmetro externo médio e transição de fase ocorrendo em uma faixa estreita de temperaturas $\left(0,5-1,0^{\circ}\right.$ C) foram obtidos por vaporização de clorofórmio e comparados com vesículas sonicadas de DODAC (cerca de $250 \AA$ de diâmetro externo).

Sacarose foi impermeante atravēs de lipossomos grandes de DODAC ou de vesiculas sonicadas de DODÁC podendo ser utilizada para determinações de volume interno em ambas as preparações. Volume interno aparente para liposso mos grandes de DODAC foi $9,7 \pm 1,31 / \mathrm{mol}$ e para vesículas sonicadas de DODAC, 0,33 $\pm 0,201 / \mathrm{mol}$ (ađsorção de sacarose à bicamada de, respectivamente, $0,64 \pm 0,30$ e $0,20 \pm 0,08$ 1/mol). Lipossomos grandes de DODAC comportaram-se como os mômetros em relação à sacarose e ao $\mathrm{KCl}(0-50 \mathrm{mM} \mathrm{KCl})$. Já as vesículas sonicadas de DODAC foram osmoticamente não-respon sivas em relação à sacarose, floculando em presença de $\mathrm{KCl}$. Essa não-responsividade osmótica foi interpretada como decorrente da presença única e exclusiva de água de hidratação no compartimento aquoso interno das vesículas sonicadas.

Outras propriedades de lipossomos grandes de DODAC foram anälogas às apresentadas por lipossomos de fosfolípides. Permeabilidades relativas ( $\mathrm{KCl}$ como referência incorporado ao compartimento aquoso interno) do $\mathrm{NaCl}, \mathrm{HCl}$ e sacarose foram similares às descritas para lipossomos de 
fosfatidilcolina; $\mathrm{NaCl}$ e sacarose sendo tão impermeantes quanto $\mathrm{KCl}$ e $\mathrm{HCl}$, sendo ligeiramente mais permeante que $\mathrm{O}$ $\mathrm{KCl}$. Nas vizinhanças da temperatura de transição de fase, ocorreu um acentuado aumento da velocidade inicial de encoIhimento e a extensão total de encolhimento chegou a um mínimo.

A comparação de algumas propriedades físicas e funcionais de vesículas sonicadas e de lipossomos grandes de DODAC permitiu concluir que lipossomos grandes de DODAC constituem um modelo mais adequado para estudos de transpor te.

Adicionalmente, o método de vaporização de clorofórmio foi testado para o dihexadecilfosfato de $\mathrm{Na}^{+}$ (DCP) sendo obtidas dispersões homogêneas desse anfifílico capazes de incorporar um volume de $13 \pm 41 / \mathrm{mol}$ e de responderem como osmômetros a gradientes osmóticos de sacarose, um soluto que praticamente não é adsorvido à bicamada de DCP e que resultou impermeante atravēs da mesma. 
ABSTRACT

Dioctadecyldimethylammonium chloride (DODAC) liposomes with $0.51 \mu$ mean external diameter and sharp phase transitions were obtained by chloroform vaporization and compared with (small) sonicated DODAC vesicles. Sucrose was impermeant through large DODAC liposomes and sonicated vesicles and was used for internal volume determinations. The apparent internal volumes for large DODAC liposomes and sonicated DODAC vesicles were, respectively, $9.7 \pm 1.3$ and $0.33 \pm 0.201 / \mathrm{mol}$. (External sucrose adsorption were, respectively, $0.64 \pm 0.30$ and $0.20 \pm 0.081 / \mathrm{mol})$. Ideal osmometer behaviour towards $\mathrm{KCl}$ over the $0-50 \mathrm{mM}$ concentrations range and towards sucrose were observed only for large DODAC liposomes. Sonicated DODAC vesicles were osmotically non responsive towards sucrose and floculate with $\mathrm{KCl}$. Other properties of large DODAC liposomes closely resembled those of phospholipid liposomes. At temperatures near the phase transition temperature, a steep increase in the initial shrinkage rate and a minimum for the total extent of shrinkage occured. Relative permeabilities (KCl as reference entrapped inside) to $\mathrm{NaCl}, \mathrm{HCl}$ and sucrose were similar to those of phosphatidyl choline liposomes. NaCl and sucrose were as impermeant as $\mathrm{KCl}$, and $\mathrm{HCl}$ slighthly more permeant than $\mathrm{KCl}$. Large DODAC liposomes are proposed as an adequate synthetic membrane model, in contrast to sonicated DODAC vesicles. In addition, the chlroform vaporization method 
was tested for sodium dihexadecylphosphate (DCP). Large DCP liposomes were demonstrated to be impermeant towards sucrose entrapping $13 \pm 41 / \mathrm{mol}$ and behaving as an osmometer towards this solute. 
REFERENCIAS

Abramson, M.B., Katzman, A.e Gregor, H.P. (1964) J.Biol. Chem.: 239,70 .

Adam, N.K. (1968) "The Physics and Chemistry of Surfaces"-New York, Dover.

Addanki, S., Cahill, R.D.e Sotos, J.F. (1968) J.Biol.Chem. 243,2337 .

Akimoto, A.; Dorn, K., Gross, L., Ringsdorf, H.e Schupp, H. (1981) Angew.Chem.Int.Ed.Eng . 20, 90 .

Babiak, S.e Testa, A.C. (1974) I.Phys.Chem. 78, 201. Bader, H., Rinsgsdorf, H.e Skura, J. (1981) Angew.Chem. Int.Ed.Eng. $\quad 20 ; 91$.

Bangham, A.D. (1968) Progr.Biophys.Mol.Biol. . $18,29$. Bangham, A.D.; Hill, M.W.e Miller, M.G.A. (1974) In "Methods in Membrane Biology" (E.D. Korn, ed.), Plenum Press, New York, p. I.

Bangham, A.D., de Gier, J.e Greville, G.D. (1967) Chem. Phys.Lipids., 225.

Bangham, A.D. e.Horne, K.W. (1964) J.Mol.Biol.' 8,660 . Bangham, A.D., Standish, M.M.e Watkins, J.C. (1965) J.Mol. Biol. 13 $3,238$.

Barenkolz, Y.; Amselem, S. e Lichtenberg, D. (1979) FEBS Lett. . 99,210 . 
Barenholz, Y.; Gibbes, D., Litman, B.J., Goll, J.; Thompson, T.E.e Carlson, F.D. (1977) Biochemistry 16, 2806 .

Barton, P.G. (1968) J.Biol.Chem. 24 2 , 3884 .

Batzri, S. e Korn, E.D. (1973) Biochim.Biophys.Acta 298, 1015 .

Baumgartnex, E. e Fuhrhop, J.H. (1980) Angew.Chem.Int.Ed. Eng: 19,550 .

Black, C., Joris, G.C.e Taylor, H.S. (1948) J.Phys.Chem. $\underline{16}: 537$.

Blok, M.C., Van Der Neut-Kok, E.C.M.; Van Deenen, L.I.M., e De Gier, J. (1975) Biochim.Biophys.Acta. . 406, 187.

Blok, M.C., Van Deenen, L.L.M.e De Gier, J. (1976) Biochim. Biophys.Acta 433,1 .

Bottchen, C.J.J.; Gent, C.M.e Van Pries, C. (1961) Ann. Chem.Acta 24,203 .

Brunner, J.; Skrobal, P.e Hauser, H. (1976) ' Biochim.Biophys. Acta $\underline{455}, 322$.

Bonner, O.D. e Choi, Y.S. (1975) J.Solution Chem. 4 , 457.

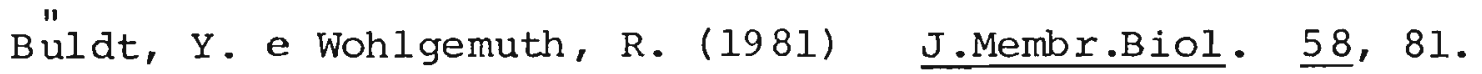
Burton, A.C. (1975) Eur.J.Cancer. 11, 365.

Cafiso, D.S. e Hubbell, W.L. (1978) Biochemistry 17, 187.

Carmona, A.M.I. (1979) Dissertação de Mestrado-- Instituto de Ciências Biomédicas da USP. 
Cass, A. e Finkelstein, A. (1967) J.Gen.Physiol. 50, 1765.

Castle, J.D. e Hubbell, W.L. (1976) Biochemistry 15, 4818 .

Chapman, D. (1975) Biomembranes.. 2, 1.

Chapman, D. (1976) Q.Rev.Biophys - ㅇ․ 185.

Chapman, D., Williams, R.M.e Ladbrooke, B.D. (1967) Chem. Phys.Lipids $\quad \underline{1}, 445$.

Clement, M.R. e Gould, J.M. (1981) Biochemistry 20, 1534 .

Clement, N.R. e Gould, J.M. (1981) Biochemistry 20, 1539 .

Cole, K.S. (1968) "Membrane, Ions and Impulses" Universi ty of California Press, Berkeley, California.

Cuccovia, I.M., Aleixo, R.M.V.,Mortara, R.A., Filho, P.B., Bonilha, J.B.S.; Quina, F.H.e Chaimovich, H. (1979)

Tetrahedron Lett. n! 33, .p. 3065.

Cuccovia, I.M.; Quina, F.H. Chaimovich, H. (1982) Tetrahedron. 38,917 .

Czarniecki, M.F.e Breslow, R. (1979) J.Am. Chem.Soc. 101, 3675 .

Darszon, A., Vanderberg, C.A.; Schönfeld, M., Ellisman, M. H., Spitzer, N.C.e Montol, M. (1980) , Proc.Natl.Acad.Sci. USA $\underline{7}, 239$.

Davies, J.T. e Rideal, E.K. (1963) "Interfacial Phenomena"-.. New York, Academic Press. 
Deamer, D.W. (1978) "Liposomes and Their Uses in Biology and Medicine" (D. Papahadjopoulos, ed.), Annals New York Academy of Sciences 308,250 .

Deamer, D. e Bangham, A.D. (1976) Biochim.Biophys.Acta 443 , 629.

Deamer, D.W., Prince, R.C. e Crofts, A.R. (1972) Biochim. Biophys.Acta 274,323 .

Deguchi, T.e Mino, J. (1978) J.Colloid Interface Sci. 65, 155.

Demel, R.A. e De Kruyff, B. (1976) Biochim.Biophys.Acta 457, 109 .

Edelberg, R. (1953). J.Cellular Comp.Physiol. $41,37$.

Enoch, H. e Strittmatter, P. (1979) Proc.Natl.Acad.Sci.USA 76, 145 .

Fendler, J.H. (1980) Acc.Chem.Res. 13, 7.

Fernāndez, M.S. (1981) Biochim.Biophys.Acta 646, 23.

Fettiplace, R., Andrews, D.M. e Haydon, D.A. (1981) J.Membrane.Biol $.5,277$.

Finer, E.G. e Darke, A. (1974) Chem.Phys.Lipids 12, 1 . Gaffney, B.J. e Mich, R.J. (1976) J.Am.Chem.Sac. 98, 3044 . Gaines, G.L. (1966) "Insoluble Monolayers at Liquid-Gas Interfaces", New York, Interscience.

Gally, H., Niederberger, W. e Seelig, J. (1975) Biochemistry 14,3647 .

Gebicki, J.M. e Hicks, M. (1976) Chem.Phys.Lipids 16, 142. 


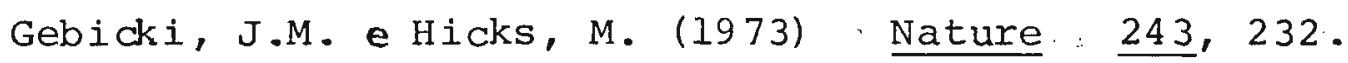

Gerson, D.F. (1978) "Cell Cycle Regulation", eds. Cameron

I.t. , Padilla, G.M. e Zimmerman, A.M. (Academic, New York) p. 105-131.

Gerson, D.F. e Burton, A.C. (1977) J.Cell.Physiol. 91, 297.

Gillies, R.J. e Deamer, D.W. (1979) "Current Topics in Bioenergetics", ed. Sanadi, R. (Academic, New York), vol. 3, p. 63-87.

Gillies, R.J. e Deamer, D.W. (1979) J.Cell.Physiol. 100, 23.

Goldacre, R.J. (1958) "Surface Phenomena in Chemistry and Biology", J.F. Danielli, K.G.A. Pankhurst, , A.C. Rid diford (eds.), Pergamon Press, Oxford.

Goldman, R. e Rottenberg, H. (1973) FEBS Lett. 33, 233. Gomperts, B.D. (1977) "The Plasma Membrane : Models for Structure and Function", Academic Press (London). Gorter, E. e Grendel, F. (1925) ‥Exp.Med. 41, 439. Gutknecht, J. ewalter, A. (1981) Biochim.Biophys.Acta $641,183$.

Haest, C.W.M., de Gier, J., van Es, G.A., Verkleij, A.J.e van Deenen, L.I.M. (1972) Biochim.Biophys.Acta $288,43 \%$ Hanai, T. e Haydon, D.A. (1966) J.Theor.Biol. 11, 370. Haydon, D.A. (1968) "Membrane Models and the Formation of Biological Membranes" (L.Bolis and B.A. Perhice, eds.) North Holland, Amsterdam, p. 91-97. 
Haydon, D.A. e Myers, V.B. (1973) Biochim.Biophys.Acta $\underline{307}, 429$.

Hamilton, R.L.Jr., Goerke, J., Gus, L.S.S., William, M.C.e Have I, R.J. (1980) J.Lipid.Res. 21, 981 .

Hargreaves, W.R. e Deamer, D.W. (1978) Biochemistry 17, 3759 .

Henglein, A., Proske, Th.e Schnecke, W. (1978) ' Ber.Bunsenges.Phys.Chem. 82,956 .

Henn, F.A. Thompson, T.E. (1969) Annu.Rev.Biochim. 38, 241 .

Henning, R. (1975) Biochim.Biophys.Acta $401,307$.

Herrmann, U. e Fendler, J.H. (1979) Chem.Phys.Letters. 64, $270 \cdot$

Hicks, M. e Gebicki, J.M. (1977) Chem.Phys.Lipids 20, 243. Huang, C. (1969) Biochemistry $\underline{8}, 344$;

Hub, H.H.; Hupfer, B., Koch, H.e Ringsdorf, H. (1980) Angew.Chem.Int.Ed.Eng. 19, 938 .

Inoue, K. (1974): Biochim.Biophys.Acta $\quad 339,390$.

Israelachvili, J.N.; Marcelja, S.e Horn, R.G. (1980) Q.Rev.

Biophys. $13,121$.

Israelachvili, J.N., Mitchell, D.J.e Ninham, B.W. (1976) J. Chem.Soc.Faraday.Trans.II. $\quad$ 72, 1525 .

Jacobson, K. $\in$ Papahadjopoulos, D. (1975) Biochemistry 14,152 , 
Jagendorff, A.T. (1975) "Bioenergetics of Photosynthesis", ed. Govindjee (Academic, New York), p. 423-492.

Jain, M.H. (1972) "The Bimolecular Lipids Membrane. A system", Van Nostrand, Reinhold Co., New York.

Jain, M.K. e Wagner, R.C. (1980) "Introduction to Biological Membranes", Wiley - Interscience, New York.

Janiak, M.J.; :Smal1, D.M. e Shipley, G.G. (1976) Biochemistry 15,4575 .

Janiak, M.J., Small, D.M.e Shipley, G.G. (1979) J.Biol. Chem. $\quad$ 254, 6068 .

Johnson, S.M. e Buttress, N. (1973) ' Biochim.Biophys.Acta.. $\underline{307}, 20$.

Johnson, R.G. e Scarpa, A. (1976) ' J.Gen.Physiol. 68, 601.

Kajiyama, T., Kumano, A., Takayanagi, M.; Okahata, Y.e Kunitake, T. (1979) Chem.Lett. 645.

Kano, K. e Fendler, J.A. (1979) Chem.Phys.Lipids 23, 189 . Kano, K., Romero, A., Djermouni, B., Ache, H.'e Fendler, J.H. (1979) J.Am..Chem.Soc. 101, 4030.

Kantor, H.L.; Mabrey, S., Prestegard, J.H. e Sturtevant, J.M. (1977) Biochim.Biophys.Acta $\quad$ 466, 402.

Katchalsky, A. e Cursan, P.F. (1967) "Non Equilibrium Thermodynamics in Biophysics", p. 713, Haward University Press, Boston.

Kinsky, S.C. (1974) "Methods in Enymology" (S.Fleischer 
and L. Parker, eds.), Academic Press, New York, 32, p. 501

Korenbrot, J.I. (1977) ․ㅡn. Rev.Physiology. $\quad \underline{39}, 19$.

Kornberg, R.D.e MCConnell, H.M. (1971) Biochemistry 10, 1111 .

Kornberg, R.D. McNamee, M.G.e McConnel1, H.M. (1972) Proc. Nat1.Acad.Sci.USA $\quad \underline{69}, 1508$.

Kremer, J.M.H., Esker, M.W.J.V.A., Pathmamanoharan, C. e Wierseman, P.H. (1977) Biochemistry $16,3932$.

Kunitake, T., Nakashima, M.; Hayaskida, S., Yonemori, K. (1979) Chem.Let. . 1413.

Kunitake, T.,Nakashima, M.e Morimitsu, K. (1980b) Chem.Lett, 1347

Kunitake, T., Nakashima, N.,Shimomura, M.e Okahata, Y. (1980a ) J.Am.Chem.Soc. 102,6642 .

Kunitake, T. e Okahata, Y. (1977) Chem.Lett, 1337.

Kunitake, T. e Okahata, Y. (1977) J.Am.Chem.Soc. 99, 3860 .

Kunitake, T. e Okahata, Y. (1978) Bull.Chem.Soc.Jpn. 51, 1877.

Kunitake, T. e Okahata, Y. (1980) J.Am.Chem.Soc. 102, 549.

Kunitake, T., Okahata, Y., Tamaki, K., Takayanagi, M.e Kumamura, F. (1977) Chem.Lett. ,387.

Kunitake, T. e Sakamoto, T. (1978) J.Am.Chem.Soc. 100, 4615 . 
Kunitake, T. e Yamada, S. (1978) Polymer Bull. I, 35.

Ladbrooke, B.D. e Chapman, D. (1969) Chem.Phys.Lipids $\underline{3}$, 304 .

Lakshminarayanaiahir; N. (1974) In "Electrochemistry, Vol. 4, Specialist Periodical Reports", (E.H. Thrisk, ed.), The Chemical Society, London, p. 167.

Lakshminarayanaiah, N. (1975) In "Electrochemistry, Vol. 5, Specialist Periodical Reports", (E.H. Thrisk, ed.), The Chemical Society, London, p. 132.

Lakshminarayanaiah, N. (1979) "Transport Phenomena in Membranes", Academic Press, New York.

Langmui r, I. (1920) ' Trans.Faraday.Soc. 15 III, 62.

Larrabee, A.L. (1979) Biochemistry 18, 3321.

Lee, A.G. (1977ㅁ) B Biochim.Biophys.Acta $\quad$ 472, 237.

Lee, A.G. (1977ㅁ) Biochim.Biophys.Acta $\quad \underline{472}, 285-$

Lelkes, P.I. (1979) Biochem.Biophys.Res.Commun. 90, 656 .

Lichtenberg, D., Freire, E., Schmidt, C.F., Barenholz, Y.,

Felgner, P.L. e Thompson, T.E. (1981) Biochemistry, 20, 3462 .

Litman, B.J.e Thompson, T.E. (1967) Fed.Proc. $\underline{26}, 834$.

Luzzati, V. (1968a) Biol.Membr. ㄴ, 71.

Luzzati, V.; Gulik-Krzywicki, T.e Tardieu, A. (1968b) ) Nature (London). 218, 199.

Luzzati, V.e Husson, F. (1962) J.Cell.Biol. 12, 207.

MacDonald., R.C., Simon, S.A.e Baer, E. (1976) ․ Biochemistry. 15, 885 . 
Marcelja, S. (1974므) J.Chem.Phys. 므, 3599.

Marcelja, S. (1974b) Biochim.Biophys.Acta $\quad \underline{367}, 165$.

Martonosi, M.A. (1974) " FEBS Lett. 47, 327.

Menger, F.M., Jerkunica, J.M.e Johnston, J.C. (1978) U.Am. Chem.Soc. 100, 4675 .

Milsmann, M.H.W., Schwendener, R.A.e Weder, H.G. (1978)

Biochim.Biophys.Acta $\quad$ 512, 147.

Mimms, L.T., Zampghi, G., Nozaki, Y., Tanford, C.e Reynolds, J.A. (1981) Biochemistry 20,833.

Mitchell, P. (1966) Biol.Rev.Cambridge Philos.Soc. $41,445$. Montal, M. e Mueller, P. (1972) Proc.Natl.Acad.Sci.USA 69,3561 .

Mortara, R.A., Quina, F.H.e Chaimovich, H. (1978) Biochem. Biophys.Res.Commun. 81,1080 .

Mueller, P. e Rudin, D.O. (1969) "Laboratory Techniques in Membrane Biophysics"(H. Passow and R. Stampfli, eds.) Springer, Berlin, p. 141-156.

Mueller, P.; Rudin, D.O., Tien, H.T.e Nescott,W.C.(1962a ) Natu re $\quad 194,979$.

Mueller, P., Rudin, D.O., Tien, H.T.e Wescott, W.C. (1962b) Circulation, $\quad \underline{26}, 1167$.

Mueller, P., Rudin, D.O., Tien, H.T.e Wescott, W.C. (1963) J.Phys.Chem. 67, 534 .

Mueller, P.; Rudin, D.O., Tien, H.T.e Wescott, W.C. (1964) Science 1, 379. 
Murakami, Y., Nakano, A.e Fukuya, K. (1980) J.Am.Chem.Soc. 102,4253 .

Nagamura, T., Mikara, S., Okahata, Y., Kunitake, T.e Matsuo, T. (1978) Ber.Bunsenges.Phys.Chem. 82, 1093.

Nagamura, T., Takeyama, M.e Matsuo, T. (1981) J.Phys.Chem. In press.

Nichols, J.W. e Deamer, D.W. (1976) Biochim.Biophys.Acta $\underline{45}$ ㄴ. 269.

Nichols, J.W. e Deamer, D.W. (1980) Proc.Nat1.Acad.Sci.USA $77,2038$.

Nichols, J.W.. Hill, M.W., Bangham, A.D.e Deamer, D.W. (1980) Biochim.Biophys.Acta $\quad \underline{596}, 393$.

Nichols, P. Miller, N. (1974) Biochim.Biophys.Acta 356, 184 .

Nozaki, Y. e Tanford, C. (1981) Proc.Natl.Acad.Sci.USA $\underline{76}, 4324$.

O'Brien, D.F., Whitesides, T.H.e Klingbiel, R.T. (1981) I. Polym.Sci.Polym.Lett. $19,95$.

Okahata, Y. e Kunitake, T. (1979) J.An.Chem.Soc. 101, 5231 .

Okahata, Y. e Kunitake, T. (1980) Ber.Bunsenges.Phys.Chem. $\underline{84}, 550$.

Oldfield, E., Marsden, J.e Chapman, D. (1971) Chem.Phys. Lipids $\quad$ 7,199 .

Olson, F., Hunt, C.A., Szoka, F.C., Vail, W.J. e Papahadjapou los, D. (1979) Biochim.Biophys.Acta $\quad$ 557, 9. 
Papahadjopoulos, D., Jacobson, K., Nir, S.e Irac, T. (1973) Biochim.Biophys.Acta. 311, 330 .

Papahadjopoulos, D., Nir, S.e Ohki, S. (1971) Biochim.Biophys.Acta. : 266, 561 .

Papahadjopoulos, D. e Watkins, J.C. (1967) Biochim.Biophys. Acta 135,639 .

Papahadjapoulos, D., Wilson, T.e Taber, R. (1980) "Transfer of Call Constituents into Eukaryotic Cells", Celis, J.H. Graessman, A. and Loyter, A., Ed., N.Y., Plenum Press, 155172 .

Pick, U., Rottenberg, H.e Avron, M. (1974) "Proccedings of the 3rd Internacional Congress on Photosynthesis", ed. Avron, M. (Elsevier, Amsterdam), p. 967-974.

Racker, E. (1972) - Am.Sci. 60, 56.

Racker, E. (1973) Biochem.Biophys.Res.Commun. 55, 224. Racker, E. e Hinckle, P.C. (1974) J.Membrane Biol. 17, 181 .

Razin, S. (1972) Biochim.Biophys.Acta , 265, 241. Reeves, J.P. e Dowben, R.M. (1969) I.Cell.Physiol. 72, 49.

Reeves, J.P. e Dowben, R.M. (1970) U.Membr.Biol. $\quad$ 3, 123.

Regen, S.L., Czeich, B.e Singh, A. (1980) J.Am.Chem.Soc. 102,6638 . Regen, S.L., Singh, A., Ochme, G.e Singh, M. (1981) J.Am. Chem.Soc. 103 . 
Rendi, R. (1965) J.Cell.Biol. 27, 83A.

Rendi, R. (1967) Biochim.Biophys.Acta $\quad$ 135, 333.

Rhoden, V. e Goldin, S.M. (1979) Biochemistry 18, 4163.

Robertson, J.D. (1960) Progr.Biophys.Chem. 10, 343.

Robins, D.C. Thomas, I.L. (1963) 'I.Pharm.Pharmacol • 15, 157.

Rottenberg, H. (1979) Methods Enzymol. 55F, 547.

Rottenberg, H.; Grunwald, T. Avron, M. (1972) Eur.J.Biochem. 25,54 .

Rouser, G., Nelson,.G.J., Fleischer, S.e Simon, G. (1968)

"Biological Membranes", Chapman, D. (Editor), chap. 2 : 569, New York, Academic.

Salsbury, M.J.; Darke, A.e Chapman, D. (1971) ' Chem.Phys. Lipids $\underline{8}, 142$.

Schales, O.e Schales, S.S. (1941) J.Biol.Chem. 140, 879. Schatzberg, P. (1965) ‥Polym.Sci. 10C, 87.

Schenkman, S. (1981) - Tese de Doutoramerto - Instituto de Química da USP.

Schenkman, S., Araujo, P.S., Dijkman, R.; Quina, F.H.e Chaimovich, H. (1981) Biochim.Biophys.Acta $\quad$ 649, 633.

Schenkman, S., Araujo, P.S., Sesso, A., Quina, F.H.e Chaimovich, H. (1981) Chem.Phys.Lipids . 28, 165. $\therefore$

Schieren, H., Rudolph, S., Finkelstein, M., Coleman, P.e Weis smann, G. (1978) Biochim.Biophys.Acta $\quad$ 542, 137. 
Schindler, H. e Seelig, J. (1975) Biochemistry $\underline{14}, 2283$.

Schullery, S.E., Schmidt, C.F., Felgner, P., Tillack, T.W.e Thompson, T.E. (1980) Biochemistry $19,3919$.

Seelig, A. e Seelig, J. (1974) Biochemistry $\quad \underline{13}, 4839$.

Seelig, J.e Seelig, A. (1980) Q.Rev.Biophys. 13, 19.

Sheetz, M.P. e Chan, S.F. (1972) Biochemistry 11, 4573.

Snell, F.D. e Snell, C.T. (1937) "Calorimetric Methods of Analysis",Vol. II, p. 557, D.Van Nostrand Company, Inc. $\left(N_{.} Y_{.}\right)$

Sogor, B.V.e Zull, J.E. (1975) Biochim.Biophys.Acta 375, 363.

Steim, J.M.; Tourtellote, M.E., Reinhart, J.C., McElhaney, R. N.e Rader, R.I. (1969) Proc.NatI.Acad.Sci.USA 63, 104.

Stoeckenius, W. (1962) J.Cel1.Biol. 12, 221.

Sturtevant, J.M. (1974) "Quantum Statistical Mechanics in the Natural Sciences" (B. Kursunoglu, S. Mintz e S. Widmeyer, eds.) Plenum Press, New York, p. 63.

Suurkuusk, J.; Lentz, B.R., Barenholz, Y., Biltonen, R.I.e Thompson, T.E. (1976) Biochemistry 15, 1393.

Sudhölter, E.J.R., Engberts, J.B.F.N.e Hoekstra, D. (1980) J.Am.Chem.Soc. 102, 2467 .

Suurkuusk, J., Lentz, B.R., Barenholz, Y., Biltonen, R.e Thomp son, T.E. (1976) Biochemistry 10, 2106. 
Szoka, F.Jr., Olson, F., Heath, T., Vail, W., Maykew, E. e Papahadjapoulos, D. (1980) Biochim.Biophys.Acta 601, 559 .

Szoka, F.Jr.e. Papahadjapoulos, D. (1978) Proc.Natl.Acad.

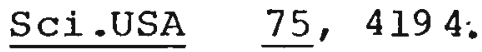

Takemoto, H., Inoue, S., Yasunaga, T.; Sukigara, M.e Toyoshi ma, Y. (1981) I.Phys.Chem. 85, 1032.

Tanford, C. (1980) "The Hydrophobic Effect:Formation of Micelles and Biological Membranes", $2^{\text {nd }}$ Edition, Wiley, Interscience, New York.

Teorell, T. (1956) Discuss Faraday Soc. $21,9$.

Tien, H.T. (1974) "Bilayer Lipid Membranes (BLM) : Theory and Practice", Marcel Dekker, New York.

Tien, H.T. (1976) Photochem.Photobiol. 24, 97.

Tien, H.T. (1979) ․ "Photosynthesis in Relation to Model Systems" (J.Barber, Ed. ) , Elsevier, Ams terdam, .. . 115.

Toll, L.e Howard, B.D. (1978) Biochemistry. 프, 2517. Tran, C.D., Klahn, P.L., Romero, A.e Fendler, J.H. (1978) J.Am.Chem.SoO. 100, 1622 .

Tundo, P., Kippenberg, D.J., Prieto, N.E., Klahn, P.L.e Fendler, J.H. (1981b) Angew.Chem.Int.Ed.Enq.

Tundo, P., Prieto, N.E., Kippenberger, D.J., Klahn, P.L., Kurihare, K., Politi, M.e Fendler, J.H. (1981ㄷ) J.Am. Chem.Soc. 103. 
Tundo, P., Kippenberger, D.J., Klahn, P.I.e Fendler, J.H. (1981a) J.Am.Chem.Soc. 103.

Tundo, P.; Kurihara, K., Prieto, N.E.; Kippenberger, D.J.; Politi, M.e Fendler, J.H.:(1981ㅁ) J.An.Chem.Soc. : 103 ,

Van Deenen, L.L.M. (1981) FEBS Lett. 123, 3.

Van Diyck, P.W.M., Ververgaert, P.H.J.T., Verkleij,A.J., Van Deenen, L.L.M.e De Gier, J. (1975) Biochim.Biophys.Acta $406,465$.

Van Holde, K.E. (1975) "Espalhamento" em"Bioquímica Física", Tradução : Alexandre Matos de Souza Melo - São Paulo, Edgard Blücher; Brasília, INL .

Vaugham, D.J.e. Keough, K.M. (1974) EEBS Lett. 느, 158. Verklij, A.J., De Kruyff, B., Ververgaert, P.H.J.T., Tocanne, J.F.e Van Deenen, L.L.M. (1974) Biochim.Biophys.Acta $\underline{339}, 432$.

Waggoner, A.S. (1976) J.Membr.Biol. $27,317$. Watts, A., Marsh, D.e Knowles, P.F. (1978) ․ Biochemistry 17,1792 .

Weisstuch, A. e Testa, A.C. (1968) J.Phys.Chem. 72, 1982 :

Zumbuehl, O.e weder, H.G. (1981) Biochim.Biophys.Acta 640,252 . 